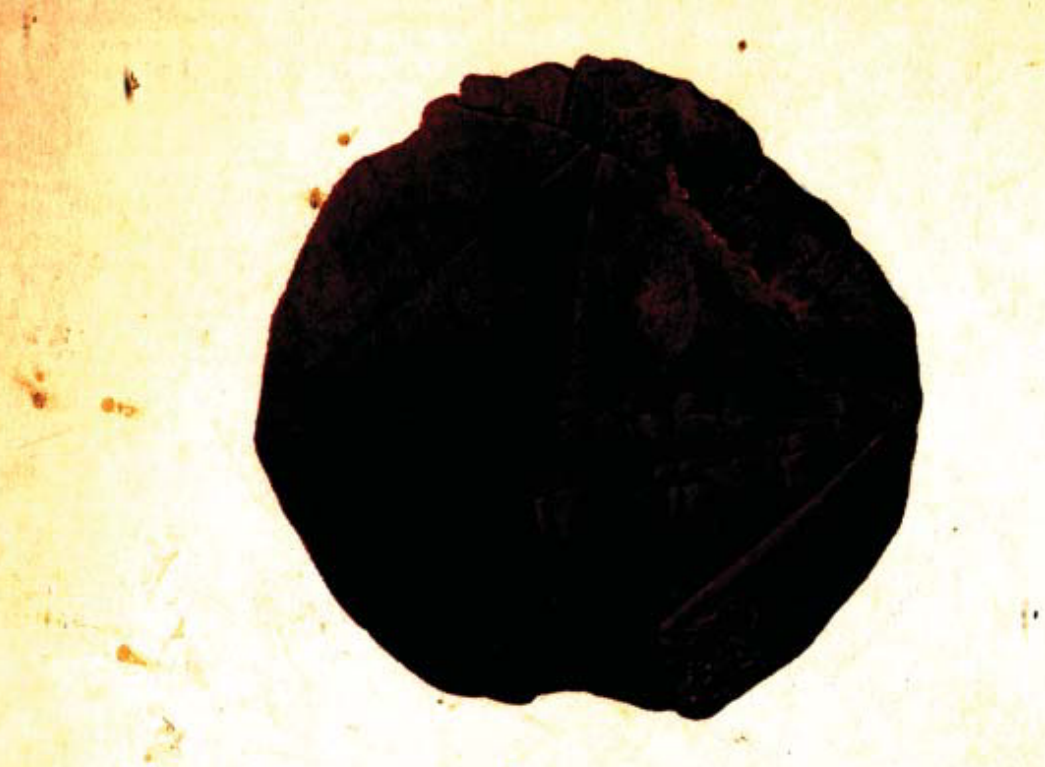

\title{
JENS HOYRUP
}

ALCERRA DR IFERTMVIER

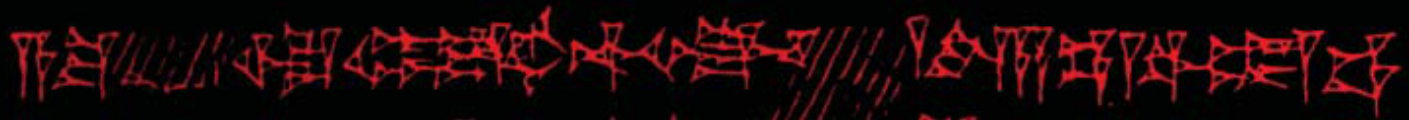

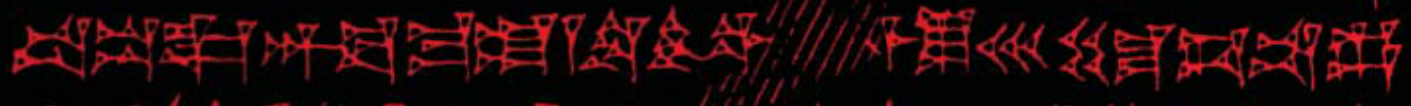

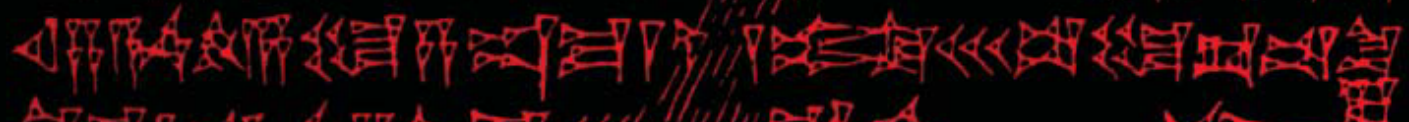

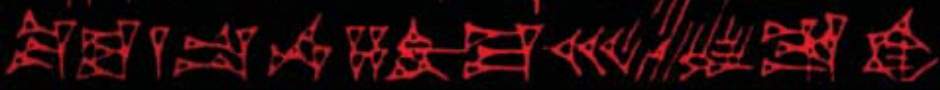

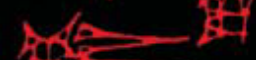




\section{JENS HOYRUP \\ ALGEBRA PÅ LERTAVLER}




\section{Algebra på lertavler}

(C) Jens Høyrup og Matematiklærerforeningen 1998

Redaktion: Hans Jørgen Schrøder og Sven Toft Jensen

Omslag Kurt Finsten

Tryk: Jysk Centraltrykkeri A/S

ISBN 87-89229-91-6

Online efter aftale med Matematiklærerforeningen (bogen er udsolgt og bliver ikke genoptrykt)

Enkelte trykfejl er rettet 
Tilegnet Arild Hvidtfeldt og til minde om Ib Schaufuss - $i$ erindring om gamle dage

\section{INDHOLD}

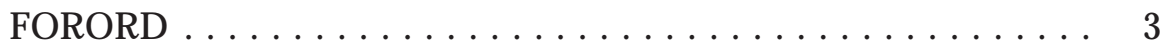

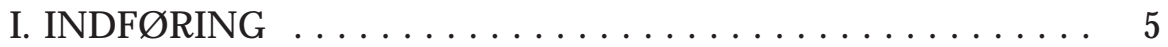

$»$ Ubrugelig matematik $« \ldots \ldots \ldots \ldots \ldots \ldots$

Den første algebra - den første tolkning $\ldots \ldots \ldots \ldots 7$

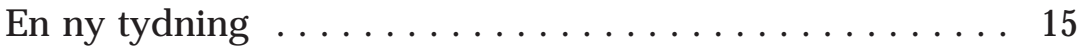

Om teksterne og oversættelserne ........... 24

II. FØRSTEGRADSLIGNINGER . . . . . . . . . . . . . . 27

TMS XVI nr. $1 \ldots \ldots \ldots \ldots \ldots \ldots \ldots \ldots \ldots \ldots$

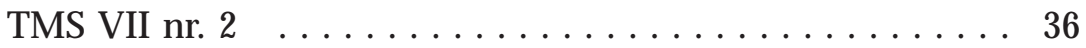

III. DE GRUNDLÆGGENDE ANDENGRADSTEKNIKKER . . . 41

BM 13901 nr. $1 \ldots \ldots \ldots \ldots \ldots$. . . . . . . . . . . . 41

BM 13901 nr. $2 \ldots \ldots \ldots \ldots \ldots \ldots \ldots \ldots \ldots \ldots$

YBC $6967 \ldots \ldots \ldots \ldots \ldots \ldots \ldots \ldots \ldots \ldots$

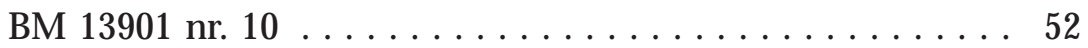

BM 13901 nr. $14 \ldots \ldots \ldots \ldots \ldots \ldots \ldots$. . . . . . . . . 54

TMS IX nr. 1 og $2 \ldots \ldots \ldots \ldots \ldots \ldots \ldots$

IV. KOMPLEKSE ANDENGRADSOPGAVER . . . . . . . 63

TMS IX nr. $3 \ldots \ldots \ldots \ldots \ldots \ldots \ldots \ldots \ldots$

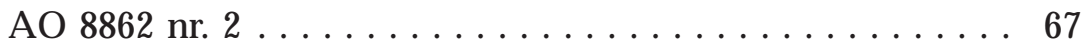

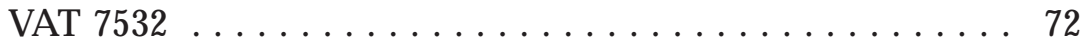

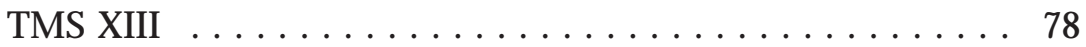

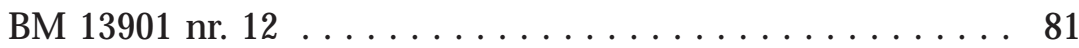

BM 13901 nr. $23 \ldots \ldots \ldots \ldots \ldots \ldots \ldots \ldots \ldots$

TMS VIII nr. $1 \ldots \ldots \ldots \ldots \ldots \ldots \ldots \ldots \ldots$

YBC 6504 nr. $4 \ldots \ldots \ldots \ldots \ldots$. . . . . . . . . . . . 89 


\section{Indholdsfortegnelse}

V. KVASI-ALGEBRAISKE TEKNIKKER I GEOMETRI M.V. . . . . 91 VAT $8512 \ldots \ldots \ldots \ldots \ldots \ldots \ldots \ldots \ldots \ldots \ldots \ldots \ldots$

BM 85200+VAT 6599 nr. 6 . . . . . . . . . . . . . . . . . 99

VI. ALMENE KENDETEGN . . . . . . . . . . . . . . . . . 104 Tegninger? . . . . . . . . . . . . . . . . . . . . . . . 104 Algebra? .............................. 106

VII. BAGGRUNDEN . . . . . . . . . . . . . . . . . . . . . . . 110

Skriverskolen ............................ 110

Første formål: træning . . . . . . . . . . . . . . . . 111

Andet formål: standsstolthed . . . . . . . . . . . . . . . 112

VIII. FORHISTORIE OG VIRKNING . . . . . . . . . . . . . . . . 114

Oprindelsen: Landmålergåder . . . . . . . . . . . . . . . . . 115

Videre liv . . . . . . . . . . . . . . . . . . . . . . . . . . . 119

IX. MORALE . . . . . . . . . . . . . . . . . . . 123

X. BIBLIOGRAFISK OVERSIGT $\ldots \ldots \ldots \ldots \ldots \ldots$

XI. APPENDIX: OPGAVER OVERLADT TIL LÆSEREN . . . . . 128

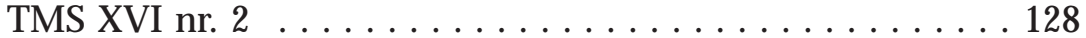

TMS VII nr. $1 \ldots \ldots \ldots \ldots \ldots \ldots \ldots$

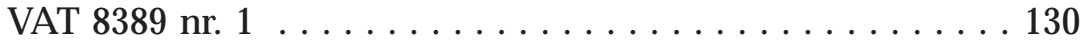

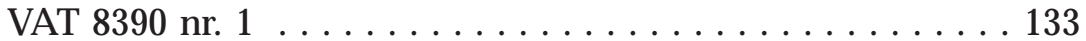

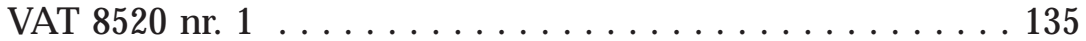

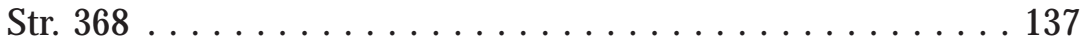

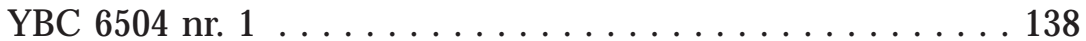

YBC 6504 nr. 3 . . . . . . . . . . . . . . . . . . . . . . . 139

BM 85200+VAT 6599 nr. 23 . . . . . . . . . . . . . . . . . . 140

$\mathrm{Db}_{2}-146 \ldots \ldots \ldots \ldots \ldots \ldots \ldots \ldots \ldots \ldots \ldots \ldots \ldots$ 


\section{FORORD}

Nærværende bog præsenterer en side af den babyloniske matematik - den såkaldte algebra. Denne »algebra« er den ældste form for »højere « matematik som vi kender til, og den behandles derfor i mange af de matematikhistoriske standardværker. I alle disse bygger fremstillingen imidlertid på oversættelser der blev foretaget i 1930erne. Denne bog tager i modsætning hertil sit udgangspunkt i de sidste 15 års forskning.

Den gængse tolkning gav oversigt over hvilke resultater babylonierne havde opnået; hvad de kunne beregne; og, så at sige, hvilke formler de kendte. Men da dens udgangspunkt var en moderne matematisk forståelse havde den ikke mulighed for at vise hvilken anderledes tankegang der ligger bag de babyloniske resultater. Formålet med det nærværende bog er at give indsigt i netop denne anderledeshed, og dermed at vise at matematik kan tænkes på flere måder.

Bogen er skrevet med henblik på brug i gymnasiets matematikundervisning. Det vil i den sammenhæng kunne anvendes på tre forskellige måder:

* Til delvis dækning af matematikkens historiske aspekt.

* Som grundlag for et valgfrit forløb.

* Som baggrund for en større skriftlig opgave.

Til førstnævnte brug vil det være lærerens opgave at uddrage passende emner. Som tekstmateriale vil det være hensigtsmæssigt at benytte de grundlæggende andengradsligninger BM 13901 nr. 1-2, YBC 6967 samt TMS IX nr. 1-2. Hvis tiden tillader det, 
vil det være en god ide at inddrage også førstegradsligningen i TMS XVI nr. 1. Baggrundsorientering kan efter lærerens vurdering trækkes fra kapitlerne I og VI-VIII.

Anvendes bogen som grundlag for et valgfrit forløb læses kapitel I, førstegradsligningen TMS XVI nr. 1 og alle de grundlæggende andengradsligninger. Derudover kan f. eks. læses TMS IX nr. 3, AO 8862 nr. 2, BM 13901 nr. 23 og YBC 6504 nr. 4. Desuden læses eller gennemgås, i det mindste kursorisk, kapitel VI-IX.

For brug af bogen som baggrund for en større skriftlig opgave, kan der ikke gives nøjere regler. Der vil dog være hensigtsmæssigt, udover hvad er anvist ved valgfrit forløb, at inddrage et antal af teksterne fra kapitel XI, hvor de vejledende kommentarer enten er sparsomme eller helt fraværende.

Jeg takker lektor Hans Jørgen Schrøder, der har gennemlæst manuskriptet. Uden hans ændringsforslag ville teksten mange steder have været mindre egnet til sit formål. At de tilbageværende ufuldkommenheder er forfatterens ansvar er det næppe nødvendigt at gøre opmærksom på.

København, november 1997 Jens Høyrup 


\section{INDFØRING}

\section{»Ubrugelig matematik«}

I slutningen af 1970erne stillede Danmarks Matematiklærerforening sine medlemmer et kildent spørgsmål: Kunne nogen af dem finde en anvendelse for andengradsligninger som lå inden for en folkeskoleelevs horisont?

Der kom faktisk et svar, så foreningen måtte bløde en flaske whisky: Sammenhængen mellem tid og tællervisning på en kassettebåndoptager. Men flere svar indkom der ikke.

Det skal nok forbavse adskillige skoleelever at heller ikke læreren ved hvad andengradsligningerne skal bruges til. Det forbavser sikkert både matematiklærere og elever at man nu har undervist $\mathrm{i}$ andengradsligninger siden omkring 1800 f.v.t. uden at have nogen anvendelser for dem inden for elevernes horisont - de første 2500 år uden at have nogen praktisk anvendelse overhovedet (omkring år 700 begyndte de persiske og arabiske astronomer at bruge dem $\mathrm{i}$ trigonometriske beregninger).

Det hele startede i bronzealderens Babylon.

Vi skal vende tilbage til spørgsmålet om hvorfor man så underviser og underviste i andengradsligninger. Men først skal vi se på hvordan de første andengradsligninger (samt et par første- og en tredjegradsligning) så ud og blev løst. Samtidig skal vi så huske på at uanset hvor meget visse af opgaverne umiddelbart ser ud til at handle om praktiske forhold (handelsregning, beregning af belejringsramper, opmåling af marker), 


\section{Lidt almen historie}

Mesopotamien (»Landet mellem floderne«) betegner siden oldtiden området mellem og omkring de to store floder Eufrat og Tigris, i grove træk altså det nuværende Iraq. Omkring 3500 f.v.t. trak havet sig så meget tilbage fra den sydlige del af området at det blev velegnet til kunstvanding, og i løbet af kort tid udvikledes her historiens første egentlige »civilisation «, et samfund baseret på byer og organiseret som stat. Kernen i statsdannelsen var de store templer, og til brug for regnskabsføring opfandt præsterne her den ældste skrift (se boxen »Kileskrift»).

Den første skrift var en ren billedskrift. Vi ved derfor ikke hvilket sprog den svarer til, og har også vanskeligt ved at tyde mange af de overlevende skriftlige dokumenter i detaljer. Men i det 3. årtusinde f.v.t. (altså perioden 3000 f.v.t. til 2000 f.v.t.) ændrede skriften karakter, og blev delvis en stavelsesskrift som man efterhånden forstår så nogenlunde. Vi ved derfor at sproget omkring 2700 f.v.t. var sumerisk, og at det sydlige Mesopotamien indtil omkring 2350 f.v.t. var delt op i et antal bystater der ofte stod i krig med hinanden, bl.a. om vandressourcerne. Af samme grund ændredes statsstrukturen sig, så en konge - den ledende feltherrre - fortrængte templerne som magtcentrum. Fra omkring 2600 f.v.t. fandt der endvidere en erhvervsspecialisering sted, som hang sammen med en kraftigt forøget brug af skriften: det var ikke længere templernes og kongemagtens topembedsmænd der beregnede og førte regnskaber. Disse opgaver varetoges i stedet af specialister, skrivere, uddannet i særlige skoler.

Omkring 2340 f.v.t. gjorde en akkadisk-talende erobrer sig til herre over hele Mesopotamien. (Akkadisk er et semitisk sprog, i slægt med arabisk og hebraisk). Den centraliserede akkadiske stat brød sammen omkring 2200 f.v.t, og området opløstes igen i bystater. Omkring 2100 f.v.t. etablerede byen Ur sig som centrum i en centraliseret stat, hvis officielle sprog igen var sumerisk; det er dog langt fra sikkert at sumerisk stadig var udbredt som dagligsprog. Dette »nysumeriske« rige var højt bureaukratiseret - måske mere end noget andet samfund i verdenshistorien - og det ser ud til at positionstalsystemet netop er blevet skabt som svar på bureaukratiets behov for bekvemme regnemetoder.

I længden var bureaukratiets omkostninger for høje, og også det nysumeriske rige brød sammen i småstatsanarki omkring 2000 f.v.t. Da centralt statsstyre efter et par hundrede år genetablereres med byen Babylon som centrum, var sumerisk definitivt et dødt sprog, og akkadisk var blevet hovedsprog i det sydlige og mellemste Mesopotamien i den babyloniske dialekt, i det nordlige i den assyriske dialekt. Sumerisk overlevede dog som prestigesprog blandt skriverne, omtrent som latin i Europa.

Perioden fra 2000 f.v.t. til den babyloniske centralstats sammenbrud omkring 1600 f.v.t. kaldes den »oldbabyloniske«. Fra dennes anden halvdel stammer alle de opgaver vi her betragter. 
så er der indholdsmæssigt tale om ren, d.v.s. ikke direkte anvendelig matematik.

\section{Den første algebra - den første tolkning}

Før man taler om algebra bør man i princippet vide hvad man mener med ordet. Indtil videre skal vi dog lade som ingenting, og først vende tilbage til dette definitionsspørgsmål til sidst i bogen. Alt hvad vi har brug for at vide lige nu er at algebra har noget at gøre med ligninger.

Da mate-

matikhistorikerne sidst i 1920erne opdagede at visse babyloniske kileskrifttekster

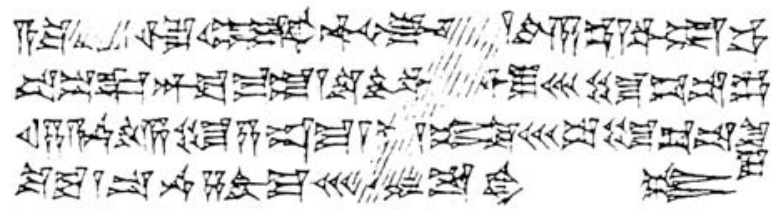

Figur 1. Kileskriftversionen af opgaven BM 13901 nr. 1.

(se boxen »Kileskriften «) indeholdt andengrads-algebra, mente de nemlig at vide hvad det betød. Lad os blot acceptere det, for at følge deres tankegang, og lad os se på et simpelt eksempel fra en lertavle fra det 18. århundrede f.v.t. i den »omskrift« som assyriologerne plejer at bruge (på Figur 1 ser vi hvordan opgaven ser ud i kileskrift):

1. A.š̀̀ ${ }^{1[a m]}$ ù mi-it-hyar-ti ak-m[ur-m]a 45-E 1 wa-și-tam

2. ta-ša-ka-an ba-ma-at 1 te-he-pe [3]0 ì 30 tu-uš-ta-kal

3. 15 a-na 45 tu-șa-ab-ma 1-E] 1 ÍB.SI 80 ša tu-uš-ta-ki-lu

4. lìb-ba 1 ta-na-sà-ah-ma 30 mi-it-har-tum 
Det ser indviklet ud, og omtrent lige så indviklet så det ud for pionererne. I mellemtiden har man fundet frem til hvad de matematiske fagudtryk betyder; men i 1928 var man nødt til at starte fra de tal der var i teksterne.

Man startede altså ud fra tallene. ${ }^{[1]}$ Man vidste allerede, at de var skrevet $i$ et positionstalsystem med grundtal 60, men uden angivelse af hvor »kommaet« skulle stå (se boxen »Trestalssystemet«). Vi gætter på at tekstens tal nok skal have forbindelse med hinanden og være af nogenlunde samme størrelsesorden som vi husker kan 1 betyde både 1,60 og 1/60. Vi kan så prøve om det giver mening at lade tallene i den rækkefølge de optræder i teksten betyde følgende:

$$
\begin{aligned}
& 45^{\prime}(=3 / 4)-1^{\circ}-1^{\circ}-30^{\prime}(=1 / 2)-30^{\prime}-15^{\prime} \\
& (=1 / 4)-45^{\prime}-1^{\circ}-1^{\circ}-30^{\prime}-1^{\circ}-30^{\prime} .
\end{aligned}
$$

Det kræver fantasi at komme videre. Det kræver at man kommer til at tænke på ligningen

$$
x^{2}+1 \cdot x=3 / 4 .
$$

Den løser vi som bekendt i følgende trin (hvis vi ser bort fra vort moderne begreb om negative tal):

$$
\begin{aligned}
x^{2}+1 \cdot x=3 / 4 & \Leftrightarrow x^{2}+1 \cdot x+(1 / 2)^{2}=3 / 4+(1 / 2)^{2} \\
& \Leftrightarrow x^{2}+1 \cdot x+(1 / 2)^{2}=3 / 4+1 / 4=1 \\
& \Leftrightarrow(x+1 / 2)^{2}=1 \\
& \Leftrightarrow x+1 / 2=\sqrt{ } 1=1
\end{aligned}
$$

\footnotetext{
${ }^{1}$ I virkeligheden startede man med tekster der var endnu sværere at knække end den vi her ser på; den blev først opdaget i 1936. Men principperne var de samme.
} 


\section{Kileskriften}

Lige fra skriftens opfindelse var det normale mesopotamiske skrivemateriale overfladen på et fladt stykke ler, som så blev tørret (en »lertavle«). I den tidligste periode blev tegnene ridset ind i leret. Disse tegn var billeder, som oftest af genkendelige genstande, og stod for enkle begreber; komplicerede begreber kunne fremstilles ved kombination af simplere tegn, som når tegnet for et hoved og for skålen med en arbejders kornration sættes sammen og får betydningen »korntildeling «.

I tidens løb ændrede

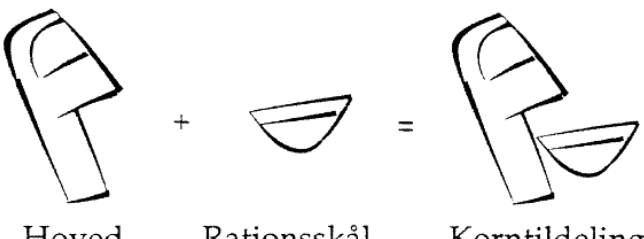

Hoved Rationsskål Korntildeling skriften karakter på to måder. For det første begyndte man, i stedet for at tegne skrifttegnene, at skitsere dem ved at en pind med skarpskårne kanter trykkes sidelæns ind; tegnene kommer så til at se ud som om de er sammensat af små kiler (heraf navnet »kileskrift«). Efterhånden blev tegnene mere og mere stiliserede, og det er ikke længere muligt at se hvad de oprindeligt forestillede. Så sent som omkring 2000 f.v.t. er der dog næppe nogen tvivl om at skriverne vidste hvilket billede der lå bag hvert tegn. Som eksempel kan vi se på udviklingen af et tegn der i sin oprindelige form (yderst til venstre) gengiver en letgenkendelig krukke med tud. I midten ser vi tre former af tegnet fra det tredie årtusinde (fordi skrifttegnene i det andet årtusinde f.v.t. blev drejet $90^{\circ}$, plejer man at gengive dem drejet også for den ældre periode); når man ved hvad de skal forestille er det stadig ikke svært at se det. Til højre har vi to varianter af tegnet fra den oldbabyloniske tid; nu er tegnet ikke længere genkendeligt.

Samtidig blev også tegne-
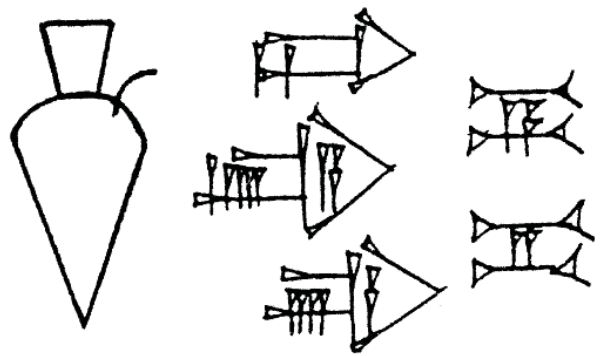

nes brug ændret. Den pågældende krukke hedder på sumerisk DUG. Da man begyndte at anvende skriften til andet end regnskaber $-\mathrm{f}$. eks. kongeindskrifter og nedskrift af ordsprog - blev der behov for at gengive stavelser der kun havde en funktion som bøjningselementer (som når på dansk hop bliver til hoppede); endnu mere vigtigt blev det når man ville gengive akkadisk. For at klare problemet begyndte man at bruge tegnene efter deres omtrentlige lydværdi; resultatet blev at tegnet kan stå for stavelserne dug, duk, tug og tuk. Samtidig kan det, i babylonisk skrift, stå som »ordtegn« for et ord der betyder det samme som DUG, selv om det på babylonisk lyder helt anderledes nemlig karpatum.

Ord der skal læses som ordtegn eller sumerisk gengives med KAPIT/ELER. Akkadisk stavelsesskrift gengives som kursiv. 


$$
\Leftrightarrow \quad x=1-1 / 2=1 / 2 .
$$

Ideen bag denne løsningsmetode er at man lægger kvadratet på den halve koefficient til $x$ - her $(1 / 2)^{2}-$ til på begge sider af lighedstegnet. Derved opnår man at venstre side kan omskrives til kvadratet på en toleddet størrelse:

$$
x^{2}+1 \cdot x+\left(\frac{1}{2}\right)^{2}=x^{2}+2 \cdot 1 / 2 \cdot x+\left(\frac{1}{2}\right)^{2}=\left(x+\frac{1}{2}\right)^{2} .
$$

Denne metode går under navnet »kvadratisk komplettering «.

Når vi sammenligner den næsten 4000 år gamle tekst og den moderne ligningsløsning ser vi at den indeholder de samme tal i stort set samme rækkefølge. Det passer ikke blot i forhold til denne tekst men i mange, opdagede man. Fra starten af 1930erne var matematikhistorikerne derfor ikke i tvivl om at de babyloniske skrivere mellem 1800 f.v.t. og 1600 f.v.t. havde noget der svarede til vor moderne ligningsalgebra. Dette tidsspand udgør anden halvdel af den såkaldte »oldbabyloniske periode« (se boxen »lidt almen historie «).

Det næste skridt i tydningen var at finde ud af hvad teksterne mere præcist sagde. Nogen hjælp kunne man få fra ordenes dagligdags betydning. I linie 1 i opgaven på side 7 kan ak-mur oversættes til »jeg har lagt i bunke«. Når to tal »lægges i bunke« er det nærliggende at tænke på en addition; men når en størrelse $a$ i andre tekster bliver »bragt til« eller »løftet til« (našûm) en størrelse $b$ kan man ikke umiddelbart regne ud hvad det betyder. Hvis man lægger mærke til at 3 »løftet til « 4 giver resultatet 12, og 5 »øftet til« 6 giver 30, ligger det dog lige for at mene at der er tale om multiplikation.

Alt i alt endte man i 1930erne med at oversætte den oven- 


\section{Trestalssystemet}

De babyloniske matematiske tekster gør brug af et "positionstalsystem « med grundtal 60, men uden angivelse af hvor »kommaet « skal stå. I vores talsystem kan cifferet 1 betyde tallet 1 , tallet 0,1 , tallet $0,01, \ldots$, samt tallene 10,100 , o.s.v. Men vi kan se på sammenhængen - afstanden til kommaet - hvilken af de mange betydninger det har.

Men når babylonierne skriver 45 kan det betyde $45 ; 45 / 60$ (altså $3 / 4$ ); 45.60; og meget mere. Det svarer til den regnestok som ingeniører regnede på inden lommeregneren tog over; også den manglede et komma, en angivelse af den absolutte størrel-sesorden. Om det nu var $3,5 \mathrm{~m}^{3}, 35 \mathrm{~m}^{3}$ eller $350 \mathrm{~m}^{3}$ beton der skulle bruges måtte man finde ud af ved hovedregning.

De enkelte tal fra 1

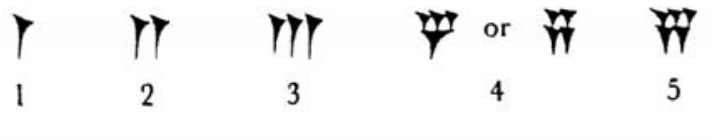
til 59 skrev babylonierne ved indtil 9 gentagelser af en lodret kile, som står for tallet $1(\Upsilon)$, og indtil 5 gentagelser af en "vinkelhage"

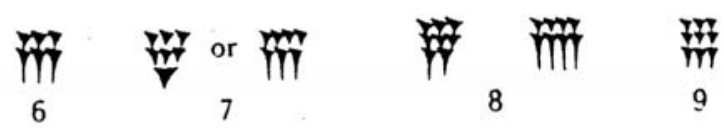
(く) der står for tallet 10.

Vi er ikke vant til at læse tal hvor vi selv skal tænke os til størrelsesordenen. Derfor plejer man når man oversætter de babyloniske matematiske tekster at angive i hvilken størrelsesorden tallene skal forstås. Det kan gøres på flere måder; i det følgende skal vi derfor gøre brug af en generalisering af den måde hvorpå man skriver grader, minutter og sekunder. Hvis et tal som $\left\langle\right.$ 'Y skal betyde ${ }^{15} / 60$, oversætter vi det $15^{\prime}$, hvis det står for $15 / 60.60$, skriver vi $15^{\prime \prime}$. Skal det betyde $15 \cdot 60$, skriver vi $15^{\prime}$, o.s.v. Hvis det betyder 15 , skriver vi 15 eller, hvis det er nødvendigt for at undgå misforståelser, $15^{\circ} .\langle$ f forstået som $10+5 \cdot 60^{-1}$ bliver altså oversat $10^{\circ} 5^{\prime}$.
《
याग
STY
forstået som $30^{\prime}$ betyder altså $1 / 2$.
forstået som $45^{\prime}$ betyder $3 / 4$.
YYY forstået som $12^{\prime}$ betyder $1 \frac{1}{5}$; forstået som $12^{\prime}$ betyder det 720 . forstået som $10^{\prime}$ betyder $1 / 6$.
kan betyde $16^{\circ} 40=1000$ eller $16^{\circ} 40^{\prime}=16^{2} \%_{3}$, o.s.v.
kan betyde $1{ }^{\prime} 40=100,1^{\circ} 40^{\prime}=1 \frac{2}{3}, 1^{\prime} 40^{\prime \prime}=1 / 36$, o.s.v.

Uden for skoleundervisningen brugte de babyloniske regnere det talsystem vi her har beskrevet til mellemregninger (som en ingeniør for tredive år siden brugte sin regnestok). Når slutresultatet skulle skrives ned i et regnskab eller lignende, måtte det selvfølgelig ikke kunne misforstås; så brugte de et andet system, som ikke rummede tvetydigheder. 
stående tekst således:

1. Jeg har adderet arealet og kvadratets (side), og det er 45'. 1 , koefficienten

2. tager du. Halvdelen (af) 1 bryder du af. 30` og 30` multiplicerer du.

3. $15^{\prime}$ tilføjer du til 45', og 1 har 1 som kvadratrod. 30' som du har multipliceret med sig selv

4. subtraherer du fra 1, og 30` er kvadratet.

Oversættelser af denne karakter har været gængse helt op til i dag. Fortolkningen passer godt med de tal der forekommer i teksten, og den får de babyloniske metoder til at se helt moderne ud. Der er ikke langt fra oversættelsen til den moderne ligningsløsning som er vist på side 8 . Hvis man kalder siden i kvadratet for $x$, er arealet $x^{2}$. Første linie i teksten - den opgave der skal løses - bliver altså til ligningen $x^{2}+1 \cdot x=3 / 4$. Hvis man går resten af oversættelsen igennem ser man at den nøje følger den moderne løsning af ligningen som vist på side 8 .

Men selv om denne og tilsvarende oversættelser passer godt til de tal der står i de babyloniske tekster, passer den kun delvis med deres ord og opbygning. Først og fremmest går oversættelserne ud fra at originalteksternes geometriske terminologi ikke var andet end et dødt billedsprog, og fra at ord og udtryk som »kvadratets side«, »længde« og »bredde« af et rektangel, »arealet« af kvadrater og rektangler blot stod for ukendte tal og deres produkter. Det så dog ikke ud til at være en umulig antagelse, i betragtning af at vi selv bruger et billedsprog af samme type: Når vi taler om $3^{2}$ som »kvadratet på 3 « tænker vi jo ikke på en firkant men på et produkt. 
Men der er andre problemer. Det største er måske at der er for mange forskellige operationer. Der findes to operationer som begge bliver til addition: at »føje til« og at »lægge i bunke«. De optræder begge i vores tekst, »bunkelægning « i linie 1 (oversat »addere «), »tilføjelse « i linie 3.

Vi kender selvfølgelig også til synonymer: vi kan addere, eller vi kan lægge sammen. Men om vi vælger det ene eller det andet ord afhænger af den stil vi taler i (f. eks. om vi prøver på at gøre indtryk på en matematiklærer eller på at forklare noget til en lillebror); vores personlige sproglige vaner, o.s.v. Sådanne synonymer kan man også finde i den babyloniske terminologi at »udrive« og at »skære af « refererer således til den samme subtraktive operation; i en situation hvor en tekst taler om at »rive ud « vil en anden kunne »skære af «. Men forskellen mellem at »føje til« og at »lægge i bunke« er af en anden art. Der findes ikke en eneste tekst hvor den »kvadratiske komplettering « (omtalt på side 10) lægger de to addender i bunke; den ene føjes altid til den anden. Bunkelægning er på den anden side det normale når sider og arealer adderes. Der er altså tale om to forskellige operationer, ikke blot om to forskellige navne der kan bruges efter forgodtbefindende. På samme måde kan man vise at der findes to forskellige »subtraktioner «; fire forskellige »multiplikationer«; og endda to forskellige »halvdele«. Det vender vi tilbage til i næste afsnit.

En oversættelse der ikke skelner mellem operationer som babylonierne anså for at være forskellige kan ganske vist forklare hvorfor deres resultater er rigtige; men den kan ikke klarlægge deres matematiske tankegang.

Det næste problem er at en del ord i teksterne må udelades 
som meningsløse. Eksempelvis burde sidste linie i oversættelsen i virkeligheden lyde »subtraherer du fra det indvendige af $1, \ldots \ll$. »Det indvendige af « blev imidlertid udeladt fra 1930ernes oversættelse fordi det ingen mening havde i den tolkning de byggede på.

Andre oversættelser ligger så langt fra ordenes dagligdags betydning at det må vække mistanke. Det ord der sidst i linie 1 oversættes som »koefficienten « betyder ellers »noget der går ud «, specielt et fremspring på en bygning. Det kunne oversætterne ikke få mening i, så de antog rask væk at det i matematikken måtte svare til et begreb som en moderne matematiker kunne finde på at bruge.

Endelig er der ikke sjældent noget galt med teksternes opbygning - de babyloniske regnere udfører jævnligt operationerne i en anden rækkefølge end de burde hvis vores tolkning var dækkende.

Uanset disse indvendinger var 1930ernes tolkning en imponerende bedrift, og den var en glimrende første tilnærmelse. Mere hævdede den håndfuld historikere som gennemførte den normalt heller ikke. Men alle andre, også matematikhistorikerne, stillede sig hurtigt tilfreds med at oversættelserne rummede den fulde sandhed om den babyloniske »algebra «. Så overbevisende var pionerernes resultater, og så afskrækkende var besværet med at skulle læse teksterne på det babyloniske originalsprog.

At de tilsyneladende synonymer i virkeligheden var navne for forskellige operationer var der ingen som bemærkede før i 1980erne. 


\section{En ny tydning}

Den oprindelige tolkning kunne som sagt ikke gøre rede for de ord som babylonierne selv brugte for at beskrive deres metoder; den skelnede ikke mellem begreber der for babylonierne var forskellige; og den tog sin tilflugt til beregninger hvis rækkefølge ikke stemmer med babyloniernes. Strengt taget er der altså ikke tale om en egentlig tolkning men om en efterprøvelse, ved hjælp af moderne matematiske teknikker, af om babyloniernes metoder var gode nok.

En virkelig tolkning - en tydning af hvad de babyloniske regnere faktisk tænkte, mente og gjorde - må tage hensyn til to ting: For det første til den »første tilnærmelse« der blev opnået i 1930erne; for det andet til alle de niveauer i tekstmaterialet som man var tvunget til at se væk fra for at kunne komme frem til en første tilnærmelse.

I de følgende kapitler skal vi analysere en række opgavetekster i en oversættelse der svarer til en sådan tydning. Men lad os først se på hvad der kan siges alment.

\section{»Variable«}

I vores algebra opfatter vi $x$ og $y$ som repræsentanter eller navne for ubekendte tal. Vi løser selvfølgelig mange opgaver der handler om andre størrelser (priser, vægte, afstande, o.s.v.) ved hjælp af algebra, men mener så at vi repræsenterer disse størrelser ved tal. Tal er for os den grundlæggende repræsentation.

For babylonierne var den grundlæggende repræsentation geometrisk. De fleste af deres algebra-opgaver handler om rektanglers længde, bredde og areal, eller om kvadraters side og areal; vi skal ganske vist nedenfor møde et eksempel (YBC 
6967, s. 49) der handler om to ubekendte tal - men deres produkt omtales som et areal, så det er tydeligt at de netop repræsenteres af et rektangels sider.

Når liniestykker og arealer kan bruges som repræsentation hænger det sammen med et vigtigt kendetegn ved den babyloniske geometri: den handler altid om målelige størrelser. De liniestykker og arealer der optræder har måske et $u k e n d t$ måltal - men selv da har de altid et måltal, som det så gælder om at finde.

\section{Enheder}

Måling forudsætter altid en måleenhed - målte tal er benævnte tal. Det er ikke umiddelbart til at se i den opgave der citeredes på side 12, og i det hele taget ikke i ret mange af de babyloniske tekster. Sagen er at de matematiske tekster reducerede alle størrelser af en bestemt art til en standardenhed, som man så kunne tillade sig at lade være underforstået.

Standardenheden for vandrette afstande var målet NINDAN, »en stang «; kvadratsiden i vores opgave er altså $1 / 2$ NINDAN, som svarer til ca. $3 \mathrm{~m}$. Lodrette afstande derimod måltes i KUŠ, som vi for nemheds skyld kan oversætte »alen «, skønt den egentlige betydning er afstanden fra albue til fingerspids. 1 KUŠ er ca. $50 \mathrm{~cm}$, og da 1 NINDAN er 12 KUŠ, bliver denne enhed altså ca. $6 \mathrm{~m}$.

Standardenheden for arealer var $1 \mathrm{SAR}=1 \mathrm{NINDAN}^{2}$. Det samme navn havde standardenheden for rumfang, idet man simpelt hen tænkte sig grundfladen på 1 NINDAN $^{2}$ udstyret med en standardtykkelse på 1 KUŠ. Som praktisk arealenhed i landbruget brugte man 1 BUR $=30^{`}$ SAR, ca. $6 \frac{1}{2}$ ha.

Standardenheden for hulmål (brugt til hvad der opbevares i beholdere, f. eks. korn og olie) var 1 sìtA, en anelse mindre 
end 1 liter. Til praktiske formål brugte man ofte de større enheder 1 BÁN $=10$ SìLA, 1 PI = 1 ' SìLA og 1 GUR = 5` SìLA.

Endelig var standardenheden for vægt 1 šekel, ca. 8 g. Højere enheder var 1 MINA = 1 ‘ šekel og 1 GÚ = 1“ šekel, »1 æselslast « på ca. $30 \mathrm{~kg}$. Sidstnævnte enhed er Bibelens talent (hvor det underforstås at der er tale om $30 \mathrm{~kg}$ sølv).

\section{Additive operationer}

Dem er der to af. Den ene kan som sagt oversættes »at lægge $a$ og $b i$ bunke $"{ }^{[2]}$ den anden »at tilføje $r$ til $K \ll$. Tilføjelse er en konkret operation, som så at sige bevarer identiteten af $K$. Som billede kan vi bruge indeståendet på min bankkonto K; når den årlige rente $r$ (der på babylonisk faktisk hedder »det tilføjede«) tilføjes, er det nye beløb $K+r$ stadig mit indestående. Hvis en geometrisk operation tilføjer $r$ til $K$, forbliver $K$ altid på sin plads, mens $r$ om nødvendigt flyttes hen til $K$.

Bunkelægning derimod kan bruges som abstrakt addition af tal; der er således intet i vejen for at en matematikopgave lægger [måltallet for] et areal og [måltallet for] en længde i bunke. Ofte er der dog tale om en konkret samling.

Summen ved tilføjelse har intet selvstændigt navn - der er jo stadig tale om $K$. Ved bunkelægning, hvor de to addender

\footnotetext{
${ }^{2}$ Vi kunne godt bruge det gængse »at lægge $a$ og $b$ sammen«, der jo har samme grundlæggende betydning. Faren er at vi så kommer til at medtænke alt hvad der gælder for vores egen operation. I dette som $i$ alle følgende tilfælde er det vigtigt, hvis vi vil prøve at forstå hvordan babylonierne tænkte deres matematik, at vi lærer at opfatte de dagligsproglige vendingers tekniske betydning gennem deres brug i babyloniske tekster, og ikke importerer moderne betydninger og sammenhænge.
} 
på lige fod forsvinder i summen, har denne derimod sit særlige navn, som vi kan oversætte »bunken«. I en opgave hvor de to addender ikke tænkes absorberet, tales der i stedet i flertal om »de sammenbunkede« (AO 8862 nr. 2, oversat i kapitel IV, s. 67).

\section{Subtraktive operationer}

Også dem er der to af. Den ene, »at udrive a fra $B$ «, er den omvendte operation af tilføjelse; det er en konkret operation, som kun bruges når størrelsen $a$ faktisk er en del af $B$.

Den anden, konstateringen af at »A overstiger $B$ med $d$ «, er ligeledes en konkret operation, der bruges ved sammenligning mellem størrelser hvoraf den ene ikke er en del af den anden.

Differensen ved den første operation hedder naturligt nok »resten«, ved den anden »overskuddet«.

Der findes en række synonymer for at »udrive«; vi skal nedenfor møde »at skære af « (AO 8862 nr. 2, s. 67) og »at fjerne" (VAT 7532, s. 72).

\section{»Multiplikationer"}

Operationer som i den oprindelige tolkning blev opfattet som multiplikation er der hele fire af.

For det første er der den som bruges i den babyloniske version af den lille tabel (der i et trestalssystem ikke er så lille endda). Den kan oversættes »skridt på«; 7-tabellen fortæller os altså at

\section{1 skridt på 7 er 7 \\ 2 skridt på 7 er 14 \\ 3 skridt på 7 er 21}


Den underliggende ide er selvfølgelig den samme som ved dansk "gange«, der også har at gøre med at gå. Et par af de tekster vi skal møde (TMS XVI, s. 27, og TMS VII, s. 36) bruger også verbet »at $g \ddot{a}$ « for at angive at en operation gentages, enten ved at en størrelse $s$ gentages $n$ gange, med resultat $n \cdot s$ (TMS XVI), eller at den tilføjes $n$ gange til en anden størrelse $A$, med resultat $A+n \cdot s$ (TMS VII).

For det andet er der »at løfte«. Oprindelig blev termen efter alt at dømme brugt ved rumfangsberegninger: rumfanget af et prisme med grundflade G SAR og højde $h$ KUŠ findes ved at grundfladen »løftes « fra standardtykkelsen 1 KUŠ til tykkelsen $h$. Men derfra er den blevet overført til alle beregninger af en konkret størrelse ved hjælp af multiplikation. »Skridt på«, derimod, betegner en abstrakt multiplikation af tal med tal.

Den tredje »multiplikation «, »at lade p og q holde« er egentlig slet ikke nogen multiplikation. Den bruges om liniestykker $p$ $\operatorname{og} q$, og betegner konstruktionen af et rektangel med sider $p$ $\operatorname{og} q$. Men da $p$ og $q$ såvel som det areal $A$ de »holder « er målelige, angiver langt de fleste tekster efter operationen umiddelbart måltallet for rektanglet - »lad 5 og 5 holde: 25 «, uden at omtale selve multiplikationen af tallet 5 med tallet 5 . Der findes imidlertid tekster der efter konstruktionsforskriften indskyder en udtrykkelig angivelse af beregningen som en »skridt-på«-multiplikation, eller som direkte fortæller at operationen fører til at der dannes en flade; der optræder eksempler på begge dele i AO 8862 nr. 2 (s. 67). I det følgende skal vi for et rektangel der »holdes« af liniestykkerne $p$ og $q$ bruge symbolet $\sqsubset \sqsupset(p, q)$, mens $\square(a)$ står for det kvadrat som et liniestykke $a$ »holder sammen med sig selv «. De tilsvarende talmultiplikationer vil vi betegne $p \times q$ og $a \times a$. 
Heller ikke den sidste multiplikative operation, »at gentage" eller »at gentage indtil $n$ « (hvor $n$ er et helt og overskueligt lille tal), er en egentlig multiplikation. Den betegner en egentlig fysisk fordobling eller $n$-dobling $-\mathrm{f}$. eks. den fordobling at en retvinklet trekant med kateter $a$ og $b$ der frembringer rektanglet med sider $a \operatorname{og} b$.

\section{Division}

Problemet »hvad skal jeg løfte til d for at få $P$ ? « er en divisionsopgave, og svaret er $P: d$. Sådanne problemer var selvfølgelig velkendte for de babyloniske regnere, både fra algebraopgaverne og fra deres praktiske funktion: Når én mand kan grave N NINDAN vandingskanal om dagen, hvor mange mand skal jeg så have til rådighed for at få gravet 30 NINDAN på 4 dage? (Her optræder problemet endda to gange). Men division var ikke nogen speciel matematisk operation for de babyloniske regnere, kun en opgave.

Når babylonierne skulle dividere 30 med 4 slog de op i en tabel (se Figur 2). Her læste de (hvis de da ikke kunne huske det) at 4 har en IGI på 15'; så løftede de 15' til 30 (det kunne de også bruge tabeller til, hvis ikke hovedregning slog til), og fandt $7^{\circ} 30^{-} \cdot{ }^{[3]}$

\footnotetext{
${ }^{3}$ Man kan undre sig over at multiplikationen af IGI 4 med 30 er en »løftning «. Er det da ikke en multiplikation af tal med tal? Faktisk ikke, som man kan se af det udtryk der bruges når IGI 4 skal slås op i tabellen: »at fraspalte«. Ideen er altså en konkret opdeling i 4 lige store dele, hvoraf én fraspaltes. Det der deles op er oprindelig vistnok en længde, og endda længden 1` [NINDAN] og ikke længden 1 [NINDAN]. Det var ganske vist en udvikling der lå mindst 300 år tilbage i tiden; men sprogbrugen var altså blevet hængende.
} 
IGI $n$ betyder det reciprokke af $n$ som anfort $i$ tabellen (altså ikke blot tallet $1 / n$ i abstrakt forstand). Problemet $P: d$ løste babylonierne altså ved at udføre multiplikationen $P \cdot 1 / d$, hvis den mulighed forelå.

\section{Det gjorde den selvfølgelig} kun hvis $n$ stod i IGI-tabellen. Det forudsatte for det forste at $n$ er et »regulært« tal, d.v.s. at $1 / n$ kan skrives som en endelig »sexagesimalbrøk«. Men selv blandt de uendeligt mange regulære tal var det naturligvis kun en begrænset del der stod i tabellen (normalt $30 \mathrm{i}$ alt). I praktisk regning kunne man dog normalt godt regne med at $d$ var regulær. Grunden var enkel nok: Man sørgede for at gå ud fra at f. eks. den længde vandingskanal en arbejder kunne grave om dagen var et regulært tal. ${ }^{[4]}$
Af 1 , det $2 / 3 \quad 40$

Dets halvdel $\quad 30$

3, dets IGI 20

4, dets IGI $\quad 15$

5 , dets IGI $\quad 12$

6 , dets IGI $\quad 10$

8 , dets IGI $\quad 730$

9, dets IGI 640

10, dets IGI 6

12, dets $|G|$

15, dets $|G|$

16, dets $|G| \quad 345$

18, dets $|G| \quad 320$

20, dets IGI 3

24 , dets $I G \mid \quad 230$

25, dets IGI 224

27, dets IGI 21320

30 , dets $|G|$

32, dets IGI $\quad 15230$

36, dets IGI $\quad 140$

40, dets IGI $\quad 130$

45, dets IGI $\quad 120$

48, dets IGI $\quad 115$

50, dets IGI $\quad 112$

54, dets IGI $\quad 1640$

1, dets IGI 1

14 , dets IGI 5615

112 , dets IGI 50

120 , dets IGI 45

115 , dets IGI 48

120 , dets IGI 45

121 , dets IGI 442640

Figur 2. Standard-IGI-tabellen i oversættelse.

\footnotetext{
${ }^{4}$ Man kan vise at de eneste regulære tal er dem der kan skrives på formen $2^{p} \cdot 3^{q} \cdot 5^{r}$, hvor $p, q$ og $r$ er hele tal (positive, negative eller 0 ). Grunden er at 2, 3 og 5 er de eneste primtal der går op i 60. Tilsvarende er de
} 
I algebraopgaverne forekommer divisionsproblemet ofte med ikke-regulær divisor $d$. Her spørger teksterne simpelthen »hvad skal jeg løfte til $d$ for at få $P$ ? «, og svarer umiddelbart. At det altid kan lade sig gøre har en lige så enkel forklaring: Samtlige opgaver er konstrueret baglæns ud fra kendte resultater; alle divisioner går derfor op, og resultatet er altid opgaveforfatteren bekendt.

\section{Halvering}

$1 / 2$ kan være en brøk på linien med så mange andre, med $2 / 3,1 / 3,1 / 4$, o.s.v.; at halvere er i så tilfælde en multiplikation med tallet $30^{\prime}$, der på sin side regnes for et tal af samme type som tallene $40^{\prime}, 2^{\prime}, 15^{\prime}$, o.s.v.

Men $1 / 2$ kan også være en halvdel som ikke kunne være noget andet. Radius i en cirkel er en sådan »nødvendig « halvdel af diameteren: den har en særlig rolle som ikke kunne indtages af nogen anden andel. Tilsvarende må det nødvendigvis være lige præcis den halve grundlinie der multipliceres med højden når en trekants areal skal beregnes; det fremgår af den simple figur der bruges ved beviset (se Figur 3).

Denne »nødvendige halvdel« havde

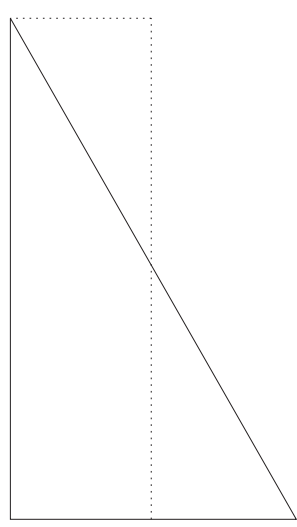

Figur 3. babylonierne et særligt navn for, som vi

»regulære« tal i titalssystemet - dem der som nævnere giver endelige decimalbrøker - tal af formen $2^{p} \cdot 5^{q}$, fordi 2 og 5 er de eneste primtal som går op i 10. 
skal oversætte »halvpart «. Processen hvorved den skabes kaldte de »at brække« (d.v.s., brække midt over).

Kvadrat og »kvadratrod «

Hverken når det gælder »løftning « eller »skridt« havde produktet $a \cdot a$ nogen speciel rolle. Et »kvadrat « var kun noget særligt når det faktisk var et [geometrisk] kvadrat.

Så var det til gengæld noget for sig. Skønt man ofte talte om at »lade $a \operatorname{og} a$ holde«, kunne man i stedet »lade a stå mod sig selv«. Selve kvadratet som geometrisk konfiguration hed »modstillingen «; som talværdi knyttet til kvadratet var denne størrelse kvadratets side ${ }^{[5]}$ Havde man fundet én side af et kvadrat, var den side den dannede hjørne med dens »modstykke«.

Havde man et kvadratisk areal $A$ og ønskede at finde siden $s$, brugtes udtrykket at " $A$ gør s ligesidet « - d.v.s., arealet $A$ lagt ud som kvadrat gør $s$ til én af de lige store sider. Undertiden omtales $s$ som » $A^{\prime}$ s ligeside «; aritmetisk svarer »ligesiden « til en kvadratrod.

Ligesom der fandtes multiplikationstabeller og IGI-tabeller, fandtes der også tabeller over kvadrater og kvadratrødder. De er bygget op, enten om vendingen $» n$ trin på $n, n^{2}$ « eller om $» n^{2}$ gør $n$ ligesidet «, med $n$ gående fra 1 til $1 `(=60)$. Ofte finder de opgavetekster vi skal se på kvadratrødder af mindre simple tal.

\footnotetext{
${ }^{5}$ Det forekommer os mærkeligt. Vi mener jo at et kvadrat er sit areal og har en side; men i sig selv er den babyloniske opfattelse, at det er sin side og har et areal, lige så god skønt anderledes end vores. Vores kvadrat viser først og fremmest hen til indholdet og dets måltal, babyloniernes »modstilling « først og fremmest til den kvadratiske ramme og dens karakteristiske mål.
} 
Babylonierne kendte en teknik til at finde tilnærmede værdier af sådanne kvadratrødder, men den gav altid netop en tilnærmet, ikke den eksakte værdi. Når teksterne finder en præcis løsning, skyldes det uden tvivl at den der har formuleret opgaven kender løsningen i forvejen, på samme måde som han kender løsningen på divisionsspørgsmålet »hvad skal jeg løfte til $d$ for at få $P$ ? «

\section{Om teksterne og oversættelserne}

De oprindelige tekster er skrevet på babylonisk, det sprog der taltes i Babylonien i den oldbabyloniske epoke, og grundstammen i de fleste tekster er skrevet med stavelsesskrift - det der er skrevet i kursiv i opgaven på side 7. De indeholder imidlertid et større eller mindre indslag af sumeriske ordtegn - det der er skrevet med KAPITÆLER (se også boxen »kileskriften«). Sumerisk var det oprindeligt dominerende sprog i området, og vedblev at fungere som kultursprog omtrent som latin i Vesteuropa. Nogle af disse ordtegn svarede til sumeriske låneord, ord som allerede havde været brugt af de sumeriske skrivere - IGI er et eksempel. Andre fungerede som forkortelser for babyloniske ord, omtrent som vi kan bruge forkortelsen »etc. « og udtale den »og så videre«.

Som sagt stammer teksterne fra anden halvdel af den oldbabyloniske periode; så meget kan man se ud fra sprog og skrift. En præcisere datering kan desværre sjældent gives, fordi de fleste af de matematiske tekster er blevet udgravet $i$ hemmelighed og købt af museerne hos antikvitetshandlere i Baghdad eller andetsteds.

Oversættelserne i de næste kapitler - alle foretaget af denne 
bogs forfatter - skelner ikke mellem om et ord er skrevet med stavelsesskriften eller med ordtegn. Men ellers bestræber de sig på at gengive de oprindelige tekster så præcist som muligt, både i grammatisk opbygning og ved altid at bruge forskellige oversættelser for forskellige babyloniske eller sumeriske ord; til gengæld bruges den samme oversættelse hver gang det samme ord forekommer. Så vidt muligt bruges der oversættelser med samme dagligsproglige betydning som de babyloniske (f. eks. »flade« i stedet for »areal«; det babyloniske ord betyder »mark «).

Da babylonisk havde en helt anden sætningsopbygning end dansk, bliver resultatet til tider ganske kluntet; til gengæld kan den der vil bruge oversættelserne til at følge de oprindelige tekster linie for linie (henvisninger til hvor de findes står i det bibliografiske appendiks, side 124). For ikke at gøre oversættelserne helt ulæselige er princippet ikke fulgt til yderligheder. Således må en dansk oversættelse vælge om et navneord skal stå i bestemt eller ubestemt form; det skel findes ikke på babylonisk. Også tegnsætningen er tilføjet (og som allerede nævnt, angivelserne af tallenes størrelsesorden, ${ }^{\circ},{ }^{\prime}$ og $\left.{ }^{\prime}\right)$. Tal der er skrevet med taltegn er oversat til arabertal; tal der står med ord i originalen er oversat til ord (og blandinger til blandinger, eksempelvis 17.-delen).

Lertavler holder sig bedre end papir, men mange af tavlerne er dog beskadiget. Til gengæld er sproget i de matematiske tekster temmelig ensartet, så man kan ofte rekonstruere beskadigede passager ved at gøre brug af tilsvarende men bedre bevarede sætninger andetsteds på samme tavle. De følgende oversættelser markerer af hensyn til læseligheden kun at en passage er rekonstrueret hvis den rekonstruerede ordlyd ikke kan anses for sikker $\left(\right.$ som $\left.^{i} . . .{ }^{2}\right)$; et par steder er passager som skriveren har glemt da 
han skrev tavlen af men som kan rekonstrueres ud fra paralleller andetsteds markeret som $\langle\ldots .$.$\rangle . (De oprindelige tekstudgaver$ indeholder fuld oplysning om skader og rekonstruktioner). Forklarende ord er indskudt i teksten i almindelig parentes (...).

De enkelte lertavler bærer navne - normalt museumsnumre. Den allerede citerede opgave er den første på tavlen BM 13901 den tavle der har nummer 13901 i British Museums samling af lertavler. Andre er fra AO (Ancient Orient, på Louvre i Paris), VAT (Vorderasiatische Texte, Berlin) eller YBC (Yale Babylonian Collection). Tavler med mærket TMS stammer fra en udgave Textes mathématiques de Suse af tekster fra Susa, et naboområde til Babylonien (ligeledes i Louvre).

Tavlerne bærer ofte tekst på både forside (Fs) og bagside (Bs), undertiden i flere spalter og undertiden også på randen. Under alle omstændigheder er de opdelt i linier. Oversættelserne angiver linietælling og om nødvendigt spaltenummer og Fs/Bs svarende til den oprindelige tekstudgave. 


\section{FØRSTEGRADSLIGNINGER}

Vi skal mest se på babyloniernes behandling af andengradsligninger. ${ }^{[6]}$ Men da andengradsligningernes løsning ofte involverer behandling af førstegradsopgaver, vil det være nyttigt at starte med en tekst der forklarer hvordan man omformer og løser førstegradsligninger.

\section{TMS XVI nr. 1}

1. 4.-delen af bredden, fra længden og bredden har jeg udrevet, $45^{\prime}$. Du, $45^{\prime}$

2. til 4 løft, 3 ser du. 3, hvad er det? 4 og 1 sæt,

3. $50^{\prime}$ og $5^{\prime}$, at udrive, sæt. $5^{\prime}$ til 4 løft, 1 bredde. $20^{\prime}$ til 4 løft,

4. $1^{\circ} 20^{\prime}$ ser du, 4 bredder. $30^{\prime}$ til 4 løft, 2 ser du, 4 længder. 20 ', 1 bredde at udrive,

5. fra $1^{\circ} 20^{\prime}, 4$ bredder, udriv, 1 ser du. 2, længderne, og 1, 3 bredder, læg i bunke, 3 ser du.

6. IGI af 4 fraspalt, $15^{\prime}$ ser du. $15^{\prime}$ til 2, længderne, løft, 30 ser du, 30’ længden.

7. 15' til 1 løft, 15' er breddens andel. 30' og 15' behold.

8. Siden »4.-delen af bredden, at udrive«, har han sagt, fra 4 , 1 udriv, 3 ser du.

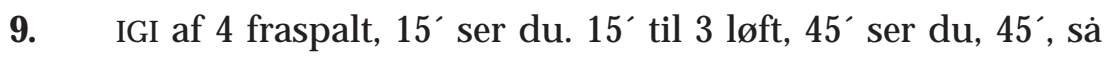

\footnotetext{
${ }^{6}$ Som da det gjaldt »algebra" skal vi i første omgang bilde os ind at vi ved hvad »en ligning « er; af arbejdet med teksterne kommer det snart til at fremgå i hvilken forstand de babyloniske opgaver kan opfattes som ligninger.
} 
meget som der er af bredder.

10. 1 , så meget som der er af længder, sæt. 20, den sande bredde, tag, 20 til 1' løft, 20' ser du.

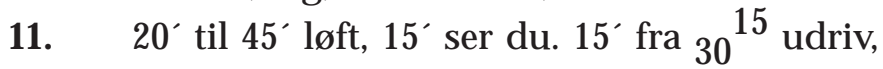

12. $30^{\prime}$ ser $\mathrm{du}, 30^{\prime}$ er længden.

Denne tekst adskiller sig fra det overvældende flertal af babyloniske matematiske tekster ved hverken at stille eller løse en opgave. I stedet giver den en pædagogisk forklaring af de begreber og procedurer man bruger for at løse en vis problemtype.

Selv om betydningen af mange ord og vendinger i oversættelsen allerede er omtalt i afsnittet »En ny tydning «, kan der være brug for at gennemgå tavlen ord for ord. Tekstens egne ord er fremhævet.

I første linie formuleres en ligning, 4.-delen af bredden, fra længden og bredden har jeg udrevet, 45'.

Ligningen handler om en længde og en bredde. Det er nok til at fortælle os at der er tale om et rektangels dimensioner - et rektangel er nemlig, fra det babyloniske synspunkt, den simpleste figur der bestemmes alene ved sin længde og sin bredde. ${ }^{[7]}$
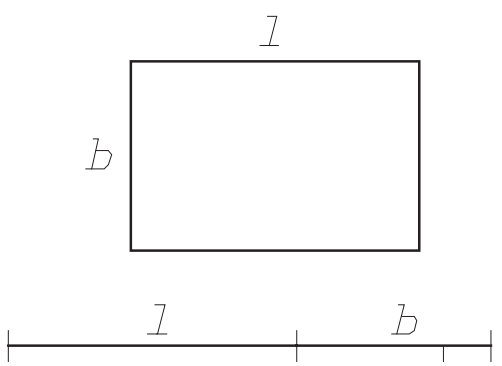

Figur 4. Geometrien i TMS XVI nr. 1.

${ }^{7}$ Hvis der er tale om en (retvinklet) trekant ville det blive sagt udtrykkeligt, hvorefter de to kateter ville blive omtalt som »længden« og »bredden« (og hypotenusen om nødvendigt omtalt som »den lange længde«). Hvis trekanten ikke kunne anses for praktisk taget retvinklet, 
Hvis vi kalder længden $l$ og bredden $b$, kan ligningen oversættes til

$$
(l+b)-1 / 4 b=45^{\prime} .
$$

Allerede ved denne oversættelse er der dog gået noget tabt. Tekstens længden og bredden er nemlig et forkortet udtryk for en bunkelægning, en abstrakt addition af to tal (se side 17). Der er altså ikke tale om at længden forlænges med bredden, men at de to størrelser samles på lige fod, uafhængigt af rektanglet. Rektanglet

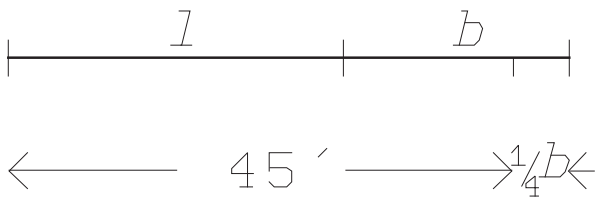

Figur 5. »Ligningen« i TMS XVI nr. 1. spiller faktisk ikke anden rolle end at stille sine sider til rådighed som variable - se Figur 4.

Efter at længden og bredden er lagt sammen kan $1 / 4 b$ udrives, idet denne størrelse er en del af den nye konfiguration »længde og bredde«. »At udrive« er jo det modsatte af »at tilføje«, altså en fjernelse af en konkret størrelse fra noget den er en del af se Figur 5.

Linie 1 viser os hvad en ligning er i babylonisk sammenhæng: En kombination af nogle målelige (oftest som her geometriske)

ville teksten indeholde en skitse.

Vendingen "praktisk taget« er vigtig. Babylonierne havde ikke noget alment begreb om målelige vinkler; derimod skelnede de klart mellem hvad vi kan kalde »rigtige« og »forkerte« vinkler, hvor de første er de praktisk taget retvinklede, dem hvis ben multipliceres med hinanden ved arealberegning. 
størrelser, hvis samlede måltal oplyses. Undertiden oplyses det i stedet at to forskellige kombinationer har samme måltal, eller at den ene overstiger den anden med så og så meget. Det er selvfølgelig ikke helt det samme som i den moderne matematikundervisnings ligninger, der normalt handler om rene tal; til gengæld er det ikke væsensforskelligt fra de ligninger som en ingeniør eller fysiker har at gøre med. Fra nu af kan vi altså bruge det moderne begreb uden forbehold.

Linie 1-2 fortæller eleven at han skal multiplicere højresidens 45' med 4: Du, 45' til 4 løft, 3 ser du. At »løfte«, husker vi, er en mangfoldiggørelse af en konkret størrelse, her af et tal der betegner en sammensat linie. Resultatet er 3, og der spørges retorisk om hvad det tal betyder: 3 , hoad er det?

Svaret på det spørgsmål kommer i de følgende linier

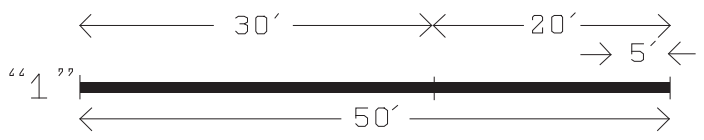
(2-5):

4 og 1 sæt: Først skal eleven »sætte« 4 og 1. »At sætte«

Figur 6. Tolkning af TMS XVI, linie 1-3. står for én eller anden form for materiel repræsentation - her antagelig simpelthen for nedskrivning af tallene på det passende sted i diagrammet (jævnfør Figur 6). Tallet »1« svarer til at ligningens højreside 45’ (og dermed også de størrelser der indgår i venstre side) umiddelbart tages én gang; tallet » 4 « sættes fordi vi skal forklare hvad der sker når 45 og de tilsvarende størrelser på linien »1《 multipliceres med 4.

Nu afsættes tallene 50' og 5' på linien »1«:50' og 5', at udrive, sæt. At det er tallene 50’ og 5' der afsættes er overraskende. Det 
kan kun forklares ved at eleven på forhånd formodes at vide at bredden er $20^{\prime}$ og at længden er 30'. Kun da ved han nemlig at $l+b=50^{\prime}$, og at $1 / 4 b$ - det der skal udrives - er $5^{\prime}$.

For forståelighedens skyld er ikke blot 50' og $5^{\prime}$ men også tallene $20^{\prime}$ og 30’ afsat på Figur 6 ved linien » 1 «, selv om teksten ikke udtrykkeligt forlanger det.

Linie 3-5 viser endnu tydeligere at eleven på forhånd må kende løsningen. Når det er tilfældet, kan formålet med tavlen ikke være at løse opgaven. Formålet er, som tidligere sagt, at forklare meningen med de begreber og procedurer man bruger for at løse en bestemt problemtype.

Linie 3-5 forklarer hvordan den oprindelige ligning

$$
(l+b)-1 / 4 b=45^{\prime}
$$

bliver til ligningen

$$
4 l+(4-1) b=3
$$

når den multipliceres med 4 på begge sider af lighedstegnet.

Udregningen kan følges i Figur 7, hvor tallene på linien » 1 « ganges op til tallene på linien $» 4 \ll$ :

$$
5^{\prime} \text { til } 4 \text { loft, } 1
$$

bredde. 20': 5', som er $1 / 4$ bredde, ganges med 4. Det giver 20',

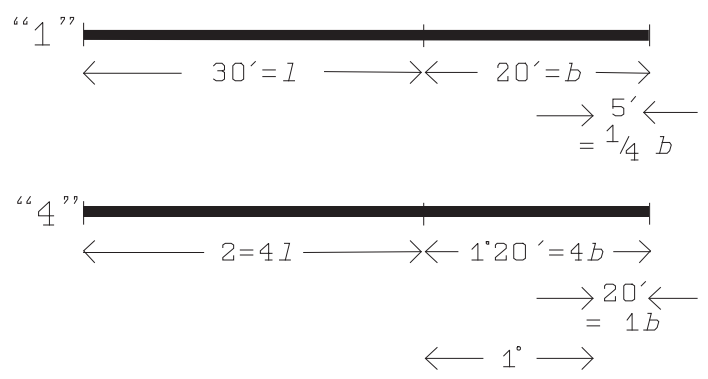

Figur 7. Tolkning af TMS XVI, linie 3-5. som er 1 bredde.

$20^{\prime}$ til 4 løft, 120' ser du, 4 bredder: 20', som er 1 bredde, 
ganges med 4 . Det giver $1^{\circ} 20^{\prime}$, som er 4 bredder.

30' til 4 løft, 2 ser du, 4 længder: 30', som er 1 længde, ganges med 4, det giver 2, som er 4 længder.

Efter at alle tallene på linien »1 1 « er ganget op til tallene på linien » 4 «, beregner teksten hvad der bliver tilbage når 1 bredde trækkes fra 4 bredder: $20^{\prime}, 1$ bredde at udrive, fra $1^{\circ} 20^{\prime}, 4$ bredder, udriv, 1 ser $d u$.

$\mathrm{Nu}$ forklares de enkelte led i venstresidens $4 l+(4-1) b$, som vist i Figur 8.

2, længderne, og $\quad$ Figur 8. Tolkning af TMS XVI, linie 5. 1,3 bredder, lxg $i$

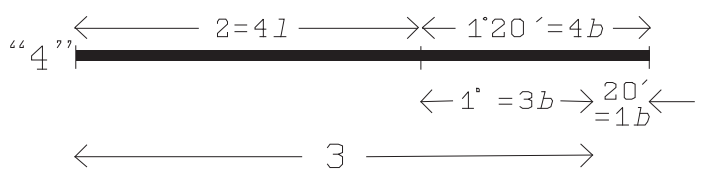
bunke, 3 ser $d u$ : 2, som er 4 længder, og 1, som er $4-1=3$ bredder, lægges sammen. Det giver tallet 3 .

Dermed er der svaret på det retoriske spørgsmål i linie 2, 3 ser du. 3, hoad er det?

Dermed slutter belæringen dog ikke. Mens de første 5 linier $i$ teksten viser hvordan ligningen $(l+b)-1 / 4 b=45^{\prime}$ kan omformes til $4 \cdot l+(4-1) \cdot b=3$, så forklarer resten af teksten hvad der svarer til at den sidste ligning omformes til

$$
1 \cdot l+3 / 4 \cdot b=45^{\prime}
$$

ved at vi dividerer med 4 på begge sider af lighedstegnet.

At dividere med 4 svarer for babylonierne til at gange med $1 / 4$. Derfor fortæller linie 6 at $1 / 4=15^{\prime}$ : IGI af 4 fraspalt, 15' ser $d u$. IGI af 4 findes som nævnt på side 20 i en IGI-tabel (en reciproktabel). 
Eleven skal nu multiplicere de enkelte bidrag med $1 / 4=15^{\prime}$. På Figur 9 svarer det til at vi går tilbage fra linien $» 4$ « til linien $» 1 \ll$ :

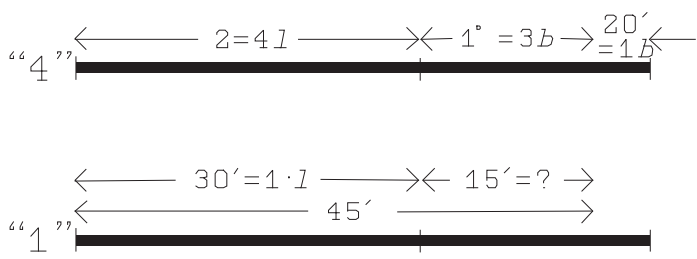

Figur 9. Tolkning af TMS XVI, linie 6-12.

$15^{\prime}$ til 2, langderne, løft, 30’ ser du, 30' længden: 2, som er 4 længder, multipliceres med $1 / 4$, det giver 30', som er 1 længde.

15' til 1 løft, 15' er breddens andel: 1, som er 3 bredder, multipliceres med $1 / 4$. Det giver $15^{\prime}$, som er breddens andel af summen $45^{\prime}$. Hvor mange bredder det svare til beregnes først i linie 8-9. $30^{\prime}$ og 15' behold: længdens og breddens andele »beholdes « i hovedet, uden nedskrift, i modsætningen til tallene 1, 4, 50' og $5^{\prime}$, der i starten af teksten blev »sat «.

Breddens andel er allerede udregnet til 15'. Linie 8-9 bestemmer hvor mange bredder det svarer til. Sidst i linie 9 gives som svar at breddens koefficient er 3/4 (45'): 45' så meget som der er af bredder. Argumentet der fører frem til denne koefficient er af en type der kaldes »simpel falsk ansats «: $:^{[8]}$

I linie 8 citeres starten af tavlen: Siden »4.-delen af bredden, at udrive", har han sagt. Vi skal altså finde ud af hvor stor en del

\footnotetext{
8 »Simpel«, fordi der også findes en »dobbelt falsk ansats«, der kan anvendes i mere komplicerede problemer. Her foretager man to forskellige gæt, ser hvor meget de hver skyder ved siden af, og interpolerer for at finde den rigtige løsning. Den bruger babylonierne dog ikke, så den kommer vi ikke til at se mere til.
} 
af bredden der er tilbage når man fjerner $1 / 4$ af den.

For nemheds skyld sætter man bredden til 4 (det er heri den »falske« ansats ligger). $1 / 4$ af 4 er 1 (det tal angiver teksten uden udregning). Når vi fjerner det, lades der 3 tilbage: fra 4 , 1 udriv, 3 ser du.

For at se hvilken del disse 3 udgør af den ansatte størrelse 4 , multiplicerer vi med $1 / 4$. Selv om det allerede er opgivet $i$ linie 6, gentages det her at $1 / 4$ er 15': IGI af 4 fraspalt, 15' ser $d u$.

Breddens koefficient $45^{\prime}=3 /{ }_{4}$ findes nu ved at $1 / 4$ multipliceres

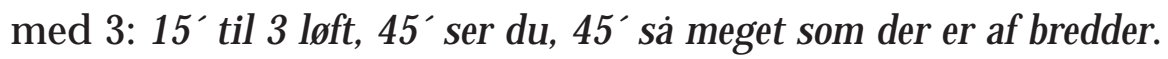

Herefter opgiver linie 10 uden beregning at længdens koefficient er 1 . Vi har jo hele tiden vidst at der indgik netop 1 længde. Dermed er det forklaret hvordan ligningen $4 \cdot 1+(4-1) \cdot b=3 \mathrm{kan}$ omformes til $1 \cdot 1+3 / 4 \cdot b=45^{\prime}$.

Slutningen af teksten (linie 10-11) indeholder en lille gåde: hvad er forholdet mellem den »sande bredde« og den bredde der optræder i opgaven?

Muligvis er forklaringen følgende: En rigtig mark kunne være 30 [NINDAN]×20 [NINDAN] (ca. $180 \mathrm{~m} \times 120 \mathrm{~m}$ ), men næppe $30^{\prime} \times 20^{\prime}(3 \mathrm{~m} \times 2 \mathrm{~m})$. Til gengæld kunne en mark på $30 \times 20 \mathrm{ikke}$ tegnes i skolegården (den mest sandsynlige placering af undervisningens diagrammer). Der passede 30’ $\times 20^{\prime}$ perfekt; dimensioner i denne størrelsesorden var da også de matematiske opgavers foretrukne. Da lertavlen ikke gør forskel på 20 og 20' eller på 1 og 1', er dette dog kun en mulig og ingen sikker forklaring.

Under alle omstændigheder udregner linie 11 endnu engang breddens andel til 15', ved at 1 bredde på 20' multipliceres med

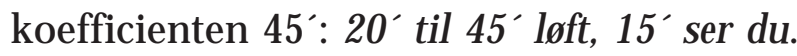


Til sidst fjernes breddens andel på 15' fra de 45' (som er skrevet i overensstemmelse med opsplitningen fra linie 7). Tilbage bliver 30', altså længden: $15^{\prime}$ fra $30^{15}$ udriv, 30’ ser du, 30' er længden.

Alt $i$ alt altså en smuk pædagogisk forklaring, der fører eleven ved hånden på kryds og tværs gennem emnet.

Før vi forlader denne opgave fortjener dens valg af grammatisk person at få en kommentar med på vejen, fordi det er karakteristisk for hovedparten af teksterne: Der startes med at et »jeg « har frembragt en situation og stiller spørgsmålet. Dernæst taler en anonym person til eleven, i bydemåde eller 2. person ental, nutid; men denne anonyme person er ikke opgaveformuleringens "jeg ", for ham refereres der til i linie 8 som den »han" der har formuleret opgaven.

Inden for den babyloniske skole er det rimeligt at se opgavestilleren som læreren, og den anonyme vejleder som en instruktør eller hjælpelærer - »storebror « kaldes han i digte om skolen. Men oprindelsen er en anden. Nogle af de tidligste tekster starter med »Hvis nogen har sagt dig: Jeg har ...«; her ses det, at opgavestilleren er en hypotetisk udefra kommende person, et påskud til en gåde; den anonyme vejleder er så læreren, der i denne oprindelige situation antagelig har været en landmåler der forklarer sin lærling fagets metoder. 
TMS VII nr. $2^{[9]}$

17. 4.-delen af bredden har jeg tilføjet til længden, dets 7.-del

18. indtil 11 er jeg gået; det overstiger bunken

19. af længde og bredde med 5'. Du, 4 sæt;

20. 7 sæt; 11 sæt; og 5' sæt.

21. $5^{\prime}$ til 7 løft, $35^{\prime}$ ser du.

22. $30^{\prime}$ og $5^{\prime}$ sæt. $5^{\prime}$ til 11 løft, 55' ser du.

23. $30^{\prime}, 20^{\prime}$ og $5^{\prime}$, at udrive, sæt. $5^{\prime}$ til 4

24. løft, 20' ser du, 20’ bredden. 30’ til 4 løft,

25. 2 ser du, 2, længder. 20’ fra 20` udriv;

26. $30^{\prime}$ fra 2 udriv, $1^{\circ} 30^{\prime}$ sæt; og 5’ til '50’, bunken af længde og bredde, tilføj?

27. 7 til 4 , fra fjerdedelen, løft, 28 ser du.

28. 11, bunker, fra 28 udriv, 17 ser du.

29. Fra 4, fjerdedelens, 1 udriv, 3 ser du.

30. IGI af 3 fraspalt, 20’ ser du. 20’ til 17 løft,

31. $5^{\circ} 40^{\prime}$ ser du, $5^{\circ} 40^{\prime}$ længden. 20’ til 5', overskuddet, løft,

32. $1^{\prime} 40^{\prime \prime}$ ser du, 1’40" tilføjelsen til længden. 540', længden,

33. fra 11 , bunken, udriv, $5^{\circ} 20^{\prime}$ ser du.

34. $1^{\prime} 40^{\prime \prime}$ til 5', overskuddet, tilføj, 6'40" ser du,

35. 6' $40^{\prime \prime}$, udrivningen fra bredden. 5', skridtet,

36. til 540', løft, 28'20" ser du.

37. 1'40", tilføjelsen til længden, til 28'20" tilføj,

\footnotetext{
${ }^{9}$ Denne opgave er forholdsvis vanskelig; den bør udelades hvis bogen bruges i forbindelse med dækningen af matematikkens historiske aspekt, og kan også med fordel springes over hvis bogen bruges som underlag for det valgfrie emne; bruger man det i forbindelse med en 3.-års opgave, kan man eventuelt gå uden om opgaven i forste omgang og vende tilbage når man ved arbejdet med de følgende tekster er blevet mere vant til den babyloniske tankegang.
} 
38. $30^{\prime}$ ser du, 30’ er længden. $5^{\prime}$ til 5²0'

39. løft, 26'40" ser du. 6'40",

40. udrivningen fra bredden, fra 26'40" udriv,

41. 20` ser du, 20` er bredden.

Denne opgave er nr. 2 fra en tavle hvor opgave nr. 1 i symbolsk oversættelse bliver til

$$
10 \cdot(1 / 7[l+1 / 4 b])=l+b .
$$

Den opgave bliver, stadig i oversættelse, reduceret til

$$
l \cdot 10=6 \cdot(l+b) .
$$

En sådan ligning er ubestemt, d.v.s., den har uendelig mange løsninger; hvis vi har fundet én løsning $\left(l_{0}, b_{\mathrm{o}}\right)$, kan samtlige løsninger skrives på formen $\left(k \cdot l_{0}, k \cdot b_{0}\right)$. Teksten finder én af dem ved at sætte første faktor på venstre side $(l)$ lig med første faktor på højre side (6), og tilsvarende med anden faktor, $l+b=10$. Dernæst sørger den for at få den i forvejen ønskede løsning ved at løfte til $5^{\prime}$ - det "skridt « på $1 / 7[l+1 / 4 b]$ som gås 10 gange. Det kan forklares ved at »skridtet « $1 / 7[l+1 / 4 b]$ med $l=6, b=4$ bliver 1 ; ønsker vi det skal blive 5' må vi multiplicere både $l$ og $b$ med denne værdi. Dette - som er indviklet nok i sig selv - er det godt at have i baghovedet når man skal forstå opgave 2 .

Opgave 1 er »homogen « - alle led er første potenser af $l$ eller $b$. Opgave 2 er mere ubehagelig, for den er inhomogen. I symbolsk oversættelse bliver den til

$$
11 \cdot(1 / 7[l+1 / 4 b])=[l+b]+5^{\prime} .
$$

Vi bemærker at $1 / 4 b$ tilføjes til længden, at vi tager $1 / 7$ heraf og dernæst »går« dette stykke 11 gange. Det overstiger så »bunken« 
af længde og bredde med et vist beløb (5'); bunken er altså ikke en del af det vi får ved det gentagne skridt (som vi skal se synes teksten faktisk at forestille sig den i breddens retning).

Opgaven starter med en pædagogisk forklaring i stil med den vi så i den foregående tekst. Ser man nøjere på hvad der foregår viser det sig at det 5' der

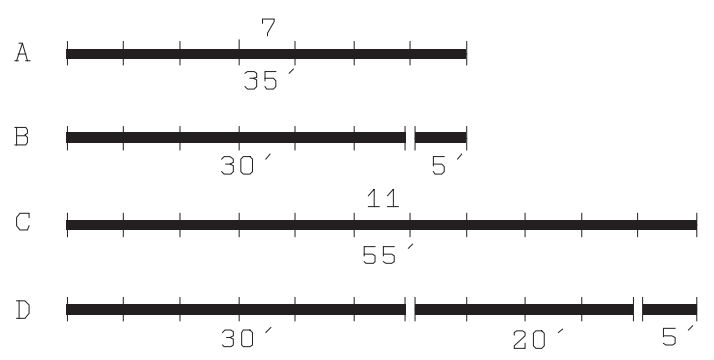

Figur 10. Tolkning af TMS VII, linie 21-23. »sættes« i linie 20 er »skridtet « $1 / 7[l+1 / 4 b]$. Det forudsættes altså bekendt at opgaven igen handler om rektanglet $\sqsubset \sqsupset\left(30^{\prime}, 20^{\prime}\right)$. Når vi har indset det kan vi følge forklaringen i linie 21-23 på Figur 10: Når »skridtet « 5' løftes til 7, får vi 35', der opløses i $l$ og $1 / 4 b$. Når det løftes til 11, fås 55', der opløses i $l, b, \operatorname{og} 5^{\prime}$.

$\mathrm{Nu}$ begynder »løsningen « af ligningen, som stadig forklares på en måde der forudsætter løsningen kendt. Vi løfter til 4, så ligningen bliver til

$$
11 \cdot(1 / 7[4 l+4 \cdot 1 / 4 b])=4 \cdot\left([l+b]+5^{\prime}\right) .
$$

Forklaringen omtaler de $4 l$ som $2,1 / 4 b$ som $5^{\prime}$, finder $4 \cdot 1 / 4 b$ som 20', og identificerer dette med en bredde.

$\mathrm{Nu}$ kommer der et elegant men svært gennemskueligt trick, som gør ligningen homogen. $4 l+b$ spaltes op til $(4-1) l-5^{\prime}+(b-b)$ $+\left(l+b+5^{\prime}\right)$, og der løftes til 7 . Vi kan følge trinnene i denne oversættelse til moderne symboler:

$$
\begin{array}{ll} 
& 11 \cdot\left([4-1] l-5^{\prime}+0+\left[l+b+5^{\prime}\right]\right)=(7 \cdot 4) \cdot\left([l+b]+5^{\prime}\right) \\
\Leftrightarrow & 11 \cdot\left([4-1] l-5^{\prime}\right)=(28-11) \cdot\left([l+b]+5^{\prime}\right)=17 \cdot\left([l+b]+5^{\prime}\right)
\end{array}
$$




$$
\begin{aligned}
& \Leftrightarrow \quad 11 \cdot\left(l-1 / 3 \cdot 5^{\prime}\right)=1 / 3 \cdot 17 \cdot\left(l+b+5^{\prime}\right) \\
& \Leftrightarrow \quad\left(l-1^{\prime} 40^{\prime \prime}\right) \cdot 11=5^{\circ} 40^{\prime} \cdot\left(l+b+5^{\prime}\right)
\end{aligned}
$$

Babylonierne skrev blot ikke i ligninger, men snarere langs kanten af figurer svarende til Figur 11; derfor udregnes »koefficienten« (4-1) først så sent.

Den sidste ligning løses igen ved at sætte faktorerne parvis lig hinanden (derfor er faktorerne byttet om på venstre side $i$ den sidste ligning): $l-1^{\prime} 40^{\prime \prime}$ (der nu kaldes »længden «, og som derfor betegnes $\lambda$ i Figur 11) sættes til

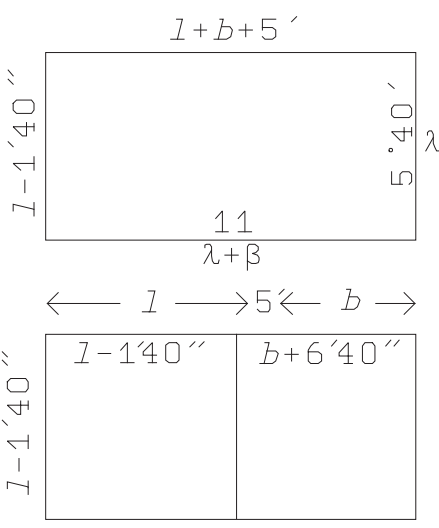

Figur 11. Løsningen på TMS VII nr. 2. $5^{\circ} 40^{\prime}$, og $l+b+5^{\prime}$ (der nu opfattes som en »bunke« af den nye længde $\lambda$ og en ny bredde $\beta$ ) bliver 11 ; $\beta$ bliver dermed $5^{\circ} 20^{\prime}$. Samtidig beregnes »tilføjelsen til længden «, det der skal tilføjes til længden $\lambda$ hvis vi vil finde den oprindelige længde $l$ - den må være 1'40" når $\lambda=l-1^{\prime} 40^{\prime \prime}$; samt »udrivningen fra bredden ", det der skal udrives fra $\beta$ hvis vi vil finde $b$. Da $l+b+5^{\prime}=11$ og altså $b=11-l-5^{\prime}=11-\left(\lambda+1^{\prime} 40^{\prime \prime}\right)-5^{\prime}=(11-\lambda)-\left(1^{\prime} 40^{\prime \prime}+5^{\prime}\right)=\beta-6^{\prime} 40^{\prime \prime}$, bliver udrivningen 6"40".

For at få de ønskede værdier for $l$ og $b$ løftes som i opgave

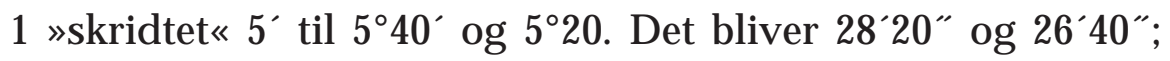
når tilføjelsen føjes til og udrivningen udrives får vi $l=30^{\prime}, b=$ 20'.

Det er værd at lægge mærke til hvor virtuost tekstens forfatter holder sig fra at bruge sin viden om hvad løsningen er i selve 
proceduren (undtagen til sidst da han skal bruge sit kendskab til »skridtet« for at få den ønskede blandt de uendelig mange mulige løsninger). De talværdier der kendes uden at være givne bruges kun i den pædagogiske forklaring og som navne - i mangel af symboler som $l$ og $\lambda$ må babylonieren tale om »længden $30^{\prime}$ « og »længden 5'40" " (begge dele er jo længder, så betegnelsen »længde« alene slår ikke til). Det er en metode der bruges i mange tekster; alligevel sker det uhyre sjældent at sammenblanding af det givne og det blot kendte fører til misforståelser. 


\section{DE GRUNDLÆGGENDE ANDENGRADSTEKNIKKER}

Vi går nu over til hovedstammen i den babyloniske algebra (vi udskyder stadigvæk den præcise afgrænsning af hvad »algebra " betyder i babylonisk sammenhæng). I dette kapitel skal vi se på nogle simple opgaver, hvor de grundlæggende teknikker kommer i brug. Kapitel IV går derefter videre med mere kompliceret stof.

\section{BM 13901 nr. 1}

Fs I

1. Fladen og min modstilling har jeg lagt i bunke: $45^{\prime}$ er det. 1 , fremspringet,

2. sætter du. Halvparten af 1 brækker du, 30’ og 30` lader du holde.

3. $15^{\prime}$ til $45^{\prime}$ tilføjer du: 1 gør 1 ligesidet. 30’ som du har ladet holde

4. fra det indvendige af 1 udriver du: $30^{\prime}$ er modstillingen.

Dette er den opgave som på side 7 blev citeret $\mathrm{i}$ assyriologernes »omskrift« og på side 12 i den traditionelle oversættelse. Vi har også set dens oversættelse til moderne ligningssprog på side 8. Selv om vi i den forstand ved hvad opgaven drejer sig om skal vi igen gennemgå teksten i detaljer med fremhævning af tavlens egne ord, for på den måde at lære hvad den går ud på i forfatterens eget perspektiv. 
I første linie stilles opgaven; den handler om en flade, her arealet af en kvadratisk figur, og den tilhørende modstilling der som forklaret på side 23 betegner den kvadratiske figur identificeret med sin side.

De to, fladen og modstillingen, lægges i bunke. Bunkelægning er den addition der må bruges ved addition af to uens størrelser, her en flade (todimensional) og en side (endimensional). Vi får at vide at summen af de to størrelsers måltal er $45^{\prime}$. Hvis vi betegner siden med $s$ og kvadratets areal med $\square(s)$, kan opgaven altså formuleres i symboler i ligningen

$$
\square(s)+s=45^{\prime}(=3 / 4) .
$$

Løsningsproceduren vises i Figur 12, hvis trin svarer til tekstens.

Figur 12A: 1, fremspringet, sætter $d u$. Det vil sige at der tegnes et rektangel $\sqsubset \sqsupset(s, 1)$, i tilknytning til kvadratet $\square(s)$. På denne måde får den i sig selv meningsløse sum af en længde og et areal en mening som et rektangulært areal $\sqsubset \exists(s, s+1)=3 / 4=45^{\prime}$. Vi bemærker at denne geometriske tolkning gør brugen af ordet »fremspring « forståelig, idet rektanglet $\sqsubset \exists(s, 1)$ kommer til at fremstå som et fremspring på en bygning. Vi husker fra side 14 at ordet i den første oversættelse blev oversat »koefficienten « fordi dets bogstavelige betydning ikke gav mening i den moderniserende tolkning.

Figur 12B: Haloparten af 1 brækker $d u$. Det fremspringende rektangel $\sqsubset \sqsupset(s, 1)$ deles i to nødvendige halvdele (»halvparter«), og den yderste (skyggede) halvpart tænkes brækket af.

Figur 12C: 30' og 30’ lader du holde. Den yderste halvpart 
flyttes så de to sider på $1 / 2=30^{\prime} \mathrm{i}$ fællesskab udspænder eller »holder« det punkterede kvadrat. Ved således, så at sige, at »klippe rektanglet $\sqsubset \sqsupset(s, s+1)$ i stykker og klistre det sammen igen « forvandler vi det til et såkaldt "gnomon«, et kvadrat hvor der mangler et kvadratisk hjørne.

Figur 12D: 15' til 45' tilføjer du: 1. $15^{\prime}$ er arealet af det påklistrede kvadrat (det som »holdes« af siderne $30^{\prime}$ og $30^{\prime}$ ), og 45' er arealet af vores gnomon. »Tilføjelse« er, som vi husker fra side 17, en konkret forøgelse af en
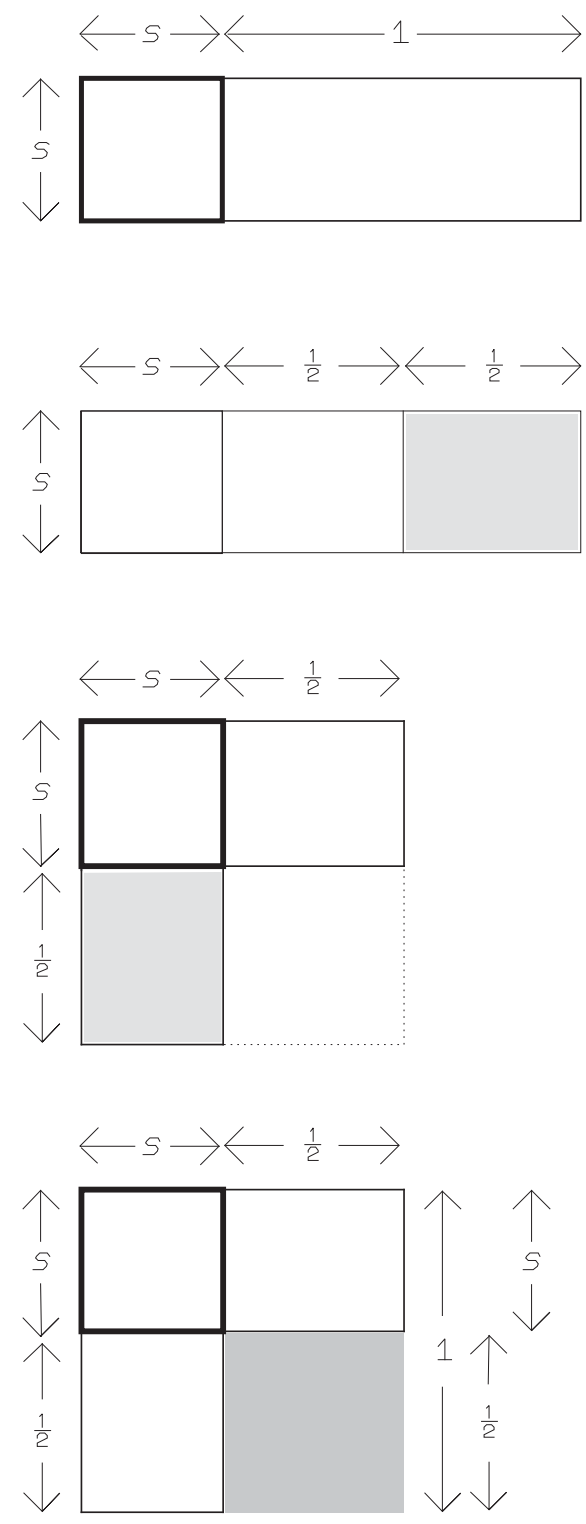

Figur 12. Proceduren i BM 13901 nr. 1, i let forvrænget målestoksforhold. 
håndgribelig størrelse (som kun kan bruges hvis de to størrelser er af samme art, f. eks. begge arealer). Vi føjer altså det manglende kvadratiske hjørne ind og forvandler derved vort gnomon til et kvadrat. Det svarer til det trick der i moderne ligningsløsning bærer navnet »kvadratisk komplettering « (se side 10). Det kompletterede kvadrats areal bliver $45^{\prime}+15^{\prime}=1$.

1 gør 1 ligesidet. At $A$ gør $s$ ligesidet « betyder, som sagt på side 23, at $A$ lagt ud som kvadrat gør $s$ til én af de lige store sider - og i moderne sprogbrug altså at $s=\sqrt{ } A$. I det nærværende tilfælde fortæller teksten altså at det kompletterede kvadrat med areal 1 har siden 1 - som indskrevet umiddelbart til højre for diagram D.

$30^{\prime}$ som du har ladet holde fra det indvendige af 1 udriver $d u$. For at finde siden $s$ i det oprindelige kvadrat fjerner vi nu det stykke $1 / 2=30^{\prime}$ som blev klistret på forneden (indskrevet én gang længere til højre). At »udrive $a$ fra $B$ « er, som vi husker fra side 18 , den omvendte operation af »tilføjelse «, en konkret operation som kun kan bruges når størrelsen $a$ faktisk er en del af $B$. Vi husker fra side 14 at ordene »det indvendige af « blev udeladt fra de første oversættelser fordi de ikke gav mening hvis opgaven handlede om rene tal; hvis tallet 1 derimod står for et liniestykke kan man derimod godt opfatte det som en størrelse med et »indre

30' er modstillingen. Når vi fjerner det tilføjede stykke på $1 / 2=30^{\prime}$ fra siden 1 , bliver der den oprindelige side $s$ - modstillingen - tilbage, som altså er 1-30' $=30^{\prime}=1 / 2$ (yderst til højre i diagram D). Dermed er opgaven løst. Som man ser passer nu ikke blot tallene, som i den gamle tolkning af teksterne, men også ordene. 
Teksten som vi nu forstår den giver anledning til nogle betragtninger. Først og fremmest bemærker vi at den aldrig beviser udtrykkeligt at dens klippeklistre-teknik fører til det

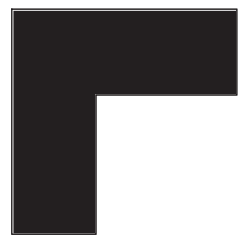

Gnomon

Figur 13. korrekte resultat; men at

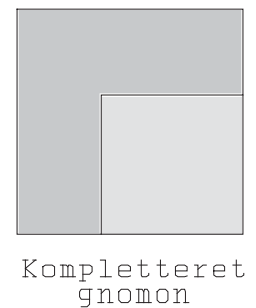

gnomon det er på den anden side er umiddelbart indlysende at det er tilfældet. Man kan tale om en "naiv« metode - og bør i den forbindelse huske på at vores normale omgang med ligninger, f. eks. i løsningen af den samme opgave på side 8, er lige så naiv; vi overvejer heller ikke skridt for skridt, vi ser blot at trinnene er indlysende rigtige uden at bekymre os om et udtrykkeligt bevis.

Det centrale trick i den babyloniske løsningsmetode er at gnomon-figuren kompletteres til et kvadrat, som i Figur 13. Metoden kaldes »kvadratisk komplettering «. Det er den samme som bruges i vore dages »symbolske løsning« (se side 8):

$$
\begin{aligned}
x^{2}+1 \cdot x=3 / 4 & \Leftrightarrow x^{2}+1 \cdot x+(1 / 2)^{2}=3 / 4+(1 / 2)^{2} \\
& \Leftrightarrow x^{2}+1 \cdot x+(1 / 2)^{2}=3 / 4+1 / 4=1 \\
& \Leftrightarrow(x+1 / 2)^{2}=1
\end{aligned}
$$

I den geometriske tolkning er navnet »kvadratisk komplettering« endnu mere indlysende end i den symbolske.

At negative løsninger ikke kunne have nogen mening for babylonierne giver sig selv i denne konkrete repræsentation. Babyloniernes algebra drejede sig om håndgribelige størrelser, selv når opgaverne ikke handlede om virkelige praktiske pro- 
blemer. Ingen længde (og intet areal, intet rumfang, ingen vægt, o.s.v.), kan være negativ. Det nærmeste de kom var en ide om størrelser der var »bestemt til at blive udrevet «; sådanne størrelser har vi mødt i TMS XVI nr. 1 (linie 3 og 4 - se side 27). ${ }^{[10]}$

En del af den matematikhistoriske sekundærlitteratur indeholder den påstand at babylonierne opererede med negative tal. Det er et eksempel på at fjer kan blive til høns ikke kun hos $\mathrm{H}$. C. Andersen men også i videnskaben. Baggrunden er at enkelte tekster af stilistiske og lignende grunde undertiden, i stedet for at sige at en størrelse $a$ overstiger en anden størrelse $b$ med overskuddet $d$, siger at $b$ er $d$ mindre end $a$ (vi skal møde et eksempel i BM $13901 \mathrm{nr}$. 10, side 52). I de første tekstudgivelsers kommentarer blev de to udtryk oversat til henholdsvis $a-b=$ $d$ og $b-a=-d$ i stedet for de mere tekstnære $a=b+d$ og $b=a-d$. De der kun læste formeloversættelserne og ikke teksterne selv fandt på denne måde negative tal »hos babylonierne«.

Som det blev sagt i forrige århundrede om de tilsvarende fejltagelser som de første oversættelser af ægyptisk matematik til moderne algebraiske symboler førte til: »Når man vil studere en videnskabs historie skal man, ganske som når man vil have et ønske opfyldt, hellere bede til den gode Gud end til hans helgener.«

\footnotetext{
${ }^{10}$ En tilsvarende størrelse optræder også i TMS VII nr. 2 (linie 35, »udrivningen af bredden " - se side 36); som vi ser i samme tavles linie 25 , opfattede babylonierne heller ikke resultatet når 20’ udrives fra 20’ som et tal men, i allerbogstaveligste forstand, som noget det ikke er værd at tale om.
} 
BM 13901 nr. 2

Fs I

5. Min modstilling fra det indvendige af fladen har jeg revet ud: 1430. 1, fremspringet,

6. sætter du. Halvparten af 1 brækker du, 30` og 30’ lader du holde,

7. $15^{\prime}$ til $14^{`} 30$ tilføjer du: $14^{`} 30^{\circ} 15^{\prime}$ gør $29^{\circ} 30^{\prime}$ ligesidet.

8. $30^{\prime}$ som du har ladet holde, til $29^{\circ} 30^{\prime}$ tilføjer du: 30 er modstillingen.

Denne tekst følger umiddelbart efter den forrige, på en tavle der $i$ alt indeholder 24 opgaver af stigende sværhedsgrad omhandlende ét eller flere kvadrater.

Opgaven er, både fra det babyloniske og fra vores synspunkt, det naturlige modstykke til nr. 1: hvor nr. 1 tilføjer, udriver denne. Metoden bygger også på samme principper: omformning af et rektangel til et gnomon, og kvadratisk komplettering.

I første linie (linie 5 på tavlen) formuleres opgaven: Min modstilling fra det indvendige affladen har jeg revet ud: 14`30. Endnu engang handler opgaven altså om et kvadrat $\square(s)$, men her rives modstillingen $s$ ud.

At $u d$ rive er en konkret subtraktion,som kun kan bruges når det man udriver er en del af det der udrives af. Modstillingen $s$ opfattes derfor som en del af det indvendige af fladen. Dette kan gøres som vist på Figur 14A, hvis man forsyner modstillingen $s$ med en standardvidde (et »fremspring «) på 1 og derved forvandler den til det tæt skraverede rektangel $\sqsubset \sqsupset(s, 1)$. Det tæt skraverede område er så det der udrives, og det tilbageblevne rektangels areal oplyses at være 1430. I moderne notation kan opgaven 
oversættes til

$$
\square(s)-s=1430 .
$$

I det tilbageblevne rektangel kender vi endnu engang forskellen mellem længden (som er s) og bredden (som er s-1); også denne gang er forskellen 1 , nemlig fremspringet.

1, fremspringet, sætter $d u$. I Figur 14B er det resterende rektangel derfor nu delt op i et (hvidt) kvadrat og et (let skraveret) overskudsrektangel hvis bredde er fremspringet 1 .

Haloparten af 1 brækker du. Overskudsrektanglet, repræsenteret ved siden 1, brækkes i to halvparter. Den halvpart der brækkes af er skygget på Figur 14C.

Ved at klippe og klistre som vist på Figur 14D får vi igen et gnomon. Dette gnomons areal er det samme som arealet af det oprindelige rektangel $\sqsubset \sqsupset(s, s-1)$, altså 1430 .

30' og 30' lader du holde, 15'. Det fremkomne gnomon kompletteres nu med det kvadrat som de to halvparter »holder«. Arealet af det lille kvadrat (mørkt skraveret på Figur 14E) er $30^{\prime} \times 30^{\prime}=15^{\prime}$.
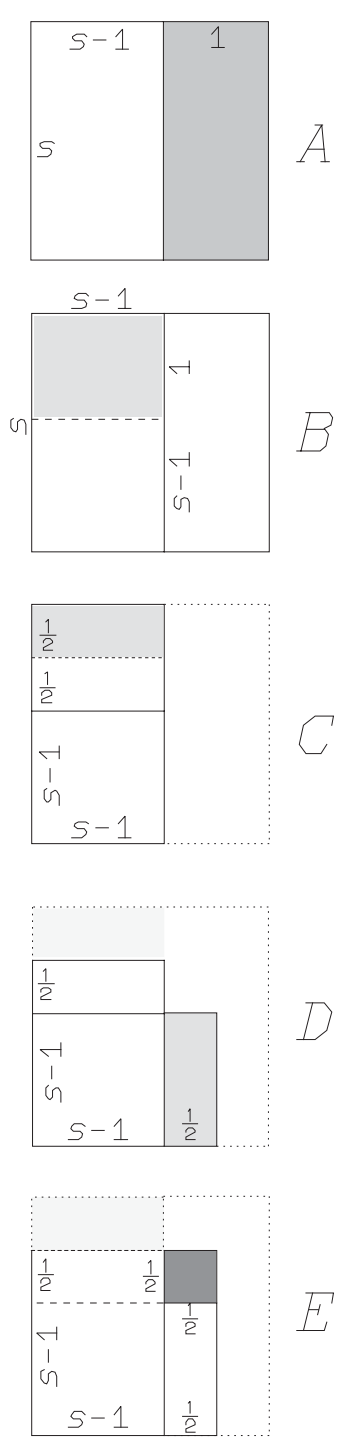

Figur 14. Proceduren i BM 13901 nr. 2.

Så udregnes arealet af det kompletterede kvadrat til 14`30¹5’: 
15' til 14`30 tilføjer du: $14{ }^{`} 30^{\circ} 15^{\prime}$.

Siden i det kompletterede kvadrat er $(s-1)+1 / 2$. Da dets areal er $14^{\prime} 30^{\circ} 15^{\prime}$, er denne side $29^{\circ} 30^{\prime}$ : $14^{\prime} 30^{\circ} 15^{\prime}$ gør $29^{\circ} 30^{\prime}$ ligesidet.

Hvis vi nu flytter den afbrækkede halvpart tilbage til der hvor den oprindelig blev klippet af, får vi gendannet det oprindelige kvadrats side, som udregnes til $29^{\circ} 30^{\prime}+30^{\prime}=30$ : 30' som du har ladet holde, til 29³0’ tilføjer du: 30 er modstillingen.

Vi bemærker at siden denne gang er 30, ikke 30'. Grunden er simpel og tvingende: hvis ikke $s>1$, skal vi udrive mere end der er til rådighed. Det kan ikke lade sig gøre: babylonierne kunne som allerede sagt tale om at en størrelse var »bestemt til at blive udrevet « men havde intet der svarede til vores begreb om negative tal.

Vi bemærker også at talparret $\left(14^{\prime} 30^{\circ} 15^{\prime}, 2^{\circ} 30^{\prime}\right)$ ikke er et af de par $\left(n^{2}, n\right)$ som findes i standardtabellen over kvadrater og kvadratrødder (se side 23); vi har her altså et eksempel på at opgaver var konstrueret ud fra en kendt løsning.

\section{YBC 6967}

Fs

1. Igibûm overstiger igûm med 7 .

2. Igûm og igibûm hvad?

3. Du, 7 hvormed igibûm

4. overstiger igûm,

5. til to bræk: $3^{\circ} 30^{\prime}$.

6. $3^{\circ} 30^{\prime}$ sammen med $3^{\circ} 30^{\prime}$

7. lad holde: $12^{\circ} 15^{\prime}$.

8. Til $12^{\circ} 15^{\prime}$ som fremkommer for dig, 
9. $\quad 1$ fladen tilføj: $1^{\prime} 12^{\circ} 15^{\prime}$.

10. Ligesiden af $1^{\prime} 12^{\circ} 15^{\prime}$ hvad? $8^{\circ} 30^{\prime}$.

11. $8^{\circ} 30^{\prime}$ og $8^{\circ} 30^{\prime}$, dets modstykke, indtegn.

Bs

1. $3^{\circ} 30^{\prime}$, det som holder,

2. fra den ene udriv,

3. til den anden tilføj.

4. Den ene bliver 12 , den anden bliver 5 .

5. 12 er igibûm, 5 er igûm.

Nok så almindelige som opgaver om kvadrater er andengradsopgaver der handler om rektangler. Der er to typeopgaver, som de mere komplicerede reduceres til. Enten kan arealet og sidernes sum være givet, eller det kan være arealet og sidernes differens.

Denne opgave er af den sidste slags, bortset fra at den formelt slet ikke handler om et rektangel men om et talpar fra IGItabellen (reciproktabellen, se side 21 og Figur 2). Igûm er simpelthen den babyloniske udtale af det sumeriske IGI, og igibûm af IGI-BI, »dets IGI« (forholdet mellem de to er jo symmetrisk: hvis 10' er IGI af 6 , så er til gengæld 6 IGI af 10’).
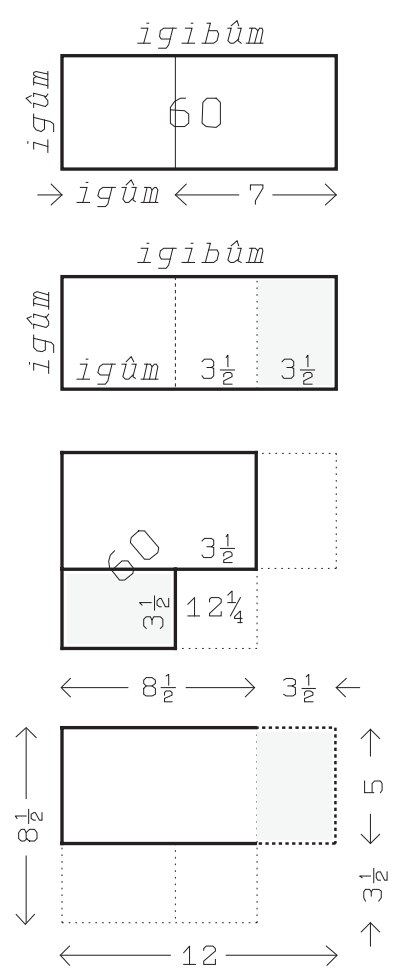

Figur 15. Proceduren i YBC 6967.

\section{(a)}


Normalt ville vi vente at produktet af igûm og igibûm var 1; det er dog ikke tilfældet her, i stedet er det 1 (altså 60). De to ukendte tal repræsenteres så af siderne i et rektangel med areal 1' (det kan vi se i linie Fs 9) - se Figur 15A, der viser situationen. Endnu engang har vi altså et rektangel hvis længde overstiger bredden med et kendt beløb, her 7 .

Det bør fremhæves at den "grundlæggende repræsentation", de geometriske størrelser, her bruges til at repræsentere størrelser af en anden art: igûm og igibûm, altså to tal. Det svarer til at vi i dag bruger rene tal i vores algebra til at repræsentere andre størrelser, såsom priser, vægte og afstande (jfr. s. 15).

I linie Fs 3-10 omdannes endnu engang rektanglet til et gnomon - og endnu engang kompletterer vi med det kvadrat der holdes af de to halvparter af overskuddet; udregningen kan følges på Figur 15B-C.

Det næste trin er værd at bemærke. Den halvpart vi klippede af og klistrede på så der blev dannet et gnomon, skal nu flyttes tilbage. Men da der jo er tale om det samme stykke der flyttes, må det nødvendigvis fjernes før det kan være til rådighed. Det har to konsekvenser. For det første fører det til at ligesiden $8^{\circ} 30^{\prime}$ »indtegnes « to gange, som vist i Figur 15D, så stykket kan fjernes fra det ene eksemplar (og derved give bredden igûm) og føjes til det andet (og derved given længden igibûm). For det andet medfører det at subtraktionen kommer før additionen i Bs 1-3, selv om babyloniernes stilfornemmelse (som vores) tilsagde dem at addition egentlig burde komme før subtraktion: $3^{\circ} 30^{\prime}$, det som holder, fra den ene udriv, til den anden tilføj.

I BM 13901 nr. 1 og 2 blev det kvadratiske komplement tilføjet til gnomon, her tilføjes i stedet gnomon til komplementet. Men 
da begge allerede er på plads og ingen flytning involveret $\mathrm{i}$ processen, er begge dele mulige. Derimod er det som sædvanlig det flyttede stykke $3^{\circ} 30^{\prime}$ der tilføjes til de $8^{\circ} 30^{\prime}$. Hvis én størrelse ligger stille og en anden flyttes hen til den, er det uvægerligt den der flyttes som føjes til. I modsætning til vores addition og babyloniernes bunkelægning er »tilføjelse« ingen symmetrisk operation.

\section{BM 13901 nr. 10}

\section{Fs II}

11. Fladerne af mine to modstillinger har jeg lagt $\mathrm{i}$ bunke, $21^{\circ} 15^{\prime}$.

12. (Fra) modstilling til modstilling, med en syvendedel er den formindsket.

13. 7 og 6 indskriver du. 7 og 7 lader du holde, 49 .

14. 6 og 6 lader du holde, 36 og 49 lægger du i bunke:

15. 1`25. IGI af $1 ` 25$ fraspaltes ikke. Hvad til $1 ` 25$

16. skal jeg sætte som giver mig $21^{\circ} 15^{\prime}$ ? $15^{\prime}$, gør $30^{\prime}$ ligesidet.

17. $30^{\prime}$ til 7 løft: $3^{\circ} 30^{\prime}$ er den første modstilling.

18. 30’ til 6 løft: 3 er den anden modstilling.

Vi er nu tilbage ved tavlen med kvadratopgaverne, ved et af de simpleste tilfælde hvor der optræder to kvadrater. I linie 11 og 12 formuleres opgaven: Vi kender summen af de to kvadraters arealer, og vi ved at siden (modstillingen) i kvadrat nr. 2 er en syvendedel kortere end siden i kvadrat nr. 1 . Hvis vi kalder de to sider $s_{1}$ og $s_{2}$, er altså

$$
\square\left(s_{1}\right)+\square\left(s_{2}\right)=21^{\circ} 15^{\prime}, \quad s_{2}=s_{1}-1 / 7 s_{1} .
$$


De to sider forholder sig med andre ord som 7 til 6 .

Det benyttes ved løsningen, der gør brug af den »simple falske ansats « (jfr. side 33). Linie 13 og 14 fortæller at vi tegner to »modelkvadrater « med siderne 7 og 6 (»lader dem holde« af siderne - se Figur 16), og finder at deres samlede areal bliver $49+36=$ 1'25. Ifølge opgaveformuleringen skal det samlede areal kun være $21^{\circ} 15^{\prime}$, så det areal vi har fundet skal reduceres med en faktor $21^{\circ} 15 \%$. $\mathrm{Nu}$ er $1 ` 25$ »ikke-regulært « (se side 22) - det har ingen IGI: IGI af 125 fraspaltes ikke. Fak-
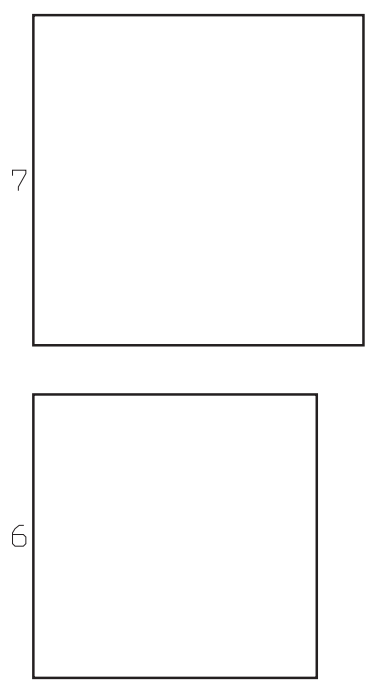

Figur 16. De to kvadrater fra BM $13901 \mathrm{nr}$. 10. toren må derfor hives ud af ærmet.

Den er, som det fremgår af linie 15-16, 15' (altså 1/4). Men hvis arealet skal reduceres med en faktor 15', er den faktor siden skal reduceres med 30': 15' gør 30' ligesidet. Tilbage står kun i linie 17 og 18 at multiplicere (»løfte«) 7 og 6 med 30’.

Den første kvadratside (»modstilling «) er altså 7.30 $=3^{\circ} 30^{\prime}$, og den anden $6 \cdot 30^{\prime}=3 .^{[11]}$

\footnotetext{
${ }^{11}$ Det er tænkeligt at metoden har været tænkt lidt anderledes: nemlig at de to oprindelige kvadrater selv deles op i hhv. $7 \times 7$ og $6 \times 6$ små kvadrater, hvis antal bliver 1`25, og som derfor hver må have arealet ${ }^{2} 1^{\circ} 15^{\prime} / 1_{25}=15^{\prime}$ og siden 30'. Dog er brugen af operationen »at holde « et tegn på at den første tolkning kommer nærmest på babyloniernes egen forståelse: de oprindelige kvadrater findes jo allerede, og skal altså
} 


\section{BM 13901 nr. 14}

\section{Fs II}

44. Fladerne af mine to modstillinger har jeg lagt $\mathrm{i}$ bunke: $25^{\prime} 25^{\prime \prime}$.

45. Modstillingen, to-tredjedele af modstillingen og $5^{\prime}$ NINDAN.

46. 1 og 40' og 5' ud over 40' indskriver du.

47. $5^{\prime}$ og $5^{\prime}$ lader du holde, $25^{\prime \prime}$ fra det indvendige af $25^{\prime} 25^{\prime \prime}$ udriver du:

Bs I

1. $25^{\prime}$ indskriver du. 1 og 1 lader du holde, 1. 40' og 40' lader du holde,

2. 26'40" til 1 tilføjer du: $1^{\circ} 26^{\prime} 40^{\prime \prime}$ til 25’ løfter du,

3. 36'6"40"' indskriver du. 5' til 40' løfter du: 3’20"

4. og 3'20" lader du holde, $11^{\prime \prime} 6^{\prime \prime} 40^{\prime \prime \prime \prime}$ til 36'6" $40^{\prime \prime \prime}$ tilføjer du:

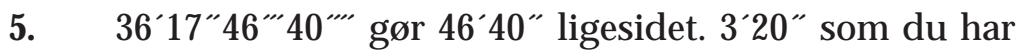
ladet holde

6. fra det indvendige af 46'40" udriver du. 43'20" indskriver $\mathrm{du}$.

7. IGI af $1^{\circ} 26^{\prime} 40^{\prime \prime}$ fraspaltes ikke. Hvad til $1^{\circ} 26^{\prime} 40^{\prime \prime}$

8. skal jeg sætte som 43'20" giver mig? 30' er dets bandûm.

9. $30^{\prime}$ til 1 løfter du: $30^{\prime}$ er den første modstilling.

10. 30' til 40’ løfter du: 20', og 5 tilføjer du:

11. $25^{\prime}$ er den anden modstilling.

Også denne opgave handler om to kvadrater, som det oplyses

ikke konstrueres (i TMS VIII nr. 1 skal vi møde en egentlig opdeling i små kvadrater, hvor antallet netop findes ved løftning - se side 88). 
i Fs II.44-45. Den ugennemsigtige formulering i line 45 betyder at kvadratside (»modstilling «) nr. 2 er to tredjedele af side nr. 1 plus $5^{\prime}$ NINDAN. Hvis vi igen kalder siderne i de to kvadrater $s_{1}$ og $s_{2}$, er ifølge linie 44 summen af arealerne $\square\left(s_{1}\right)+\square\left(s_{2}\right)=25^{\prime} 25^{\prime \prime}$, mens linie 45 fortæller at $s_{2}=40^{\prime} \cdot s_{1}+5^{\prime}$.

Denne gang kan opgaven ikke løses ved en normal falsk ansats, hvor den ubekendte forsøgsvis sættes til et bestemt tal - det kan kun homogene opgaver. ${ }^{[12]}$ Tallene 1 og 40' i linie 46 betyder i stedet at $s_{1}$ og $s_{2}$ udtrykkes i forhold til en ny størrelse som vi kan kalde $s$,

$$
s_{1}=1 \cdot s, s_{2}=40^{\prime} \cdot s+5^{\prime} \text {. }
$$

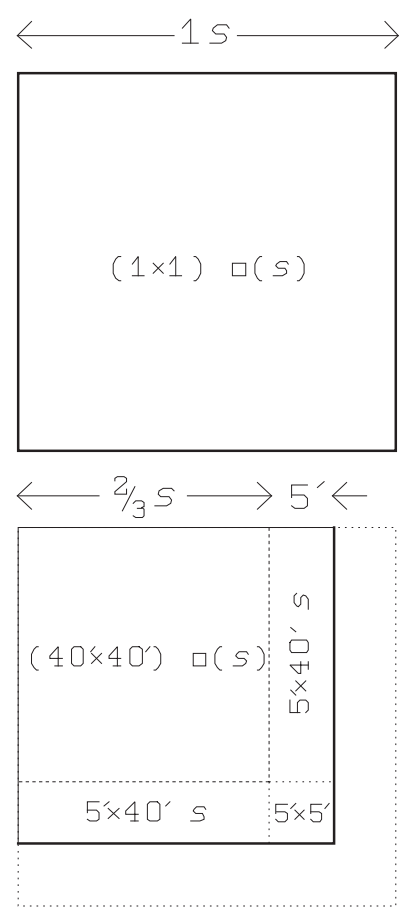

Figur 17. BM $13901 \mathrm{nr}$. 14 , de to kvadrater.

Dette svarer til Figur 17, der viser hvorledes opgaven nu kan reduceres til at handle om et enkelt kvadrat - nemlig $\square(s)$. Det er oplagt at det første af de oprindelige kvadrater (d.v.s. $\left.\square\left(s_{1}\right)\right)$ er $1 \times 1 \square(s)$, så den udregning udskydes til Bs I.1. Først ser teksten i stedet på $\square\left(s_{2}\right)$, der består af flere bidrag. I starten

\footnotetext{
${ }^{12}$ Forklaringen er at det ansatte tal skal reduceres med en faktor svarende til hvor meget resultatet rammer ved siden af; men hvis vi reducerer de ansatte værdier for $s_{1}$ og $s_{2}$ f. eks. med en faktor $1 / 5$, reduceres også leddet $5^{\prime}$ med samme faktor, altså til $1^{\prime}$.
} 
beregnes det nederste højre hjørne, kvadratet med side 5': 5' og $5^{\prime}$ lader du holde, 25". Dette bidrag trækkes fra summen af de to oprindelige kvadratarealer: 25" fra det indvendige af 25'25" udriver du: 25' indskriver $d u$. Resten på 25' skal nu bestemmes som et antal arealer og et antal sider af det nye kvadrat $\square(s)$.

$\square\left(s_{1}\right)$ er som sagt $1 \times 1=1$ kvadrat $\square(s): 1$ og 1 lader du holde, 1. ${ }^{[13]}$ Tilbage af $\square\left(s_{2}\right)$ efter at hjørnet $5^{\prime} \times 5^{\prime}$ er fjernet er der for det første et kvadrat $\square\left(40^{\prime} s\right)$; for det andet to »vinger «, som vi vender tilbage til. $\square\left(40^{\prime} s\right)$ udregnes som $\left(40^{\prime} \times 40^{\prime}\right) \square(s)=$ 26'40" $\square($ s): 40' og 40' lader du holde, 26'40". Alt i alt har vi altså $1+26^{\prime} 40^{\prime \prime}=1^{\circ} 26^{\prime} 40^{\prime \prime}$ kvadratarealer $\square(s): 26^{\prime} 40^{\prime \prime}$ til 1 tilføjer $d u$, $1^{\circ} 26^{\prime} 40^{\prime \prime}$.

Hver »vinge« er et rektangel $\sqsubset \sqsupset\left(5^{\prime}, 40^{\prime} s\right)$, som kan omregnes

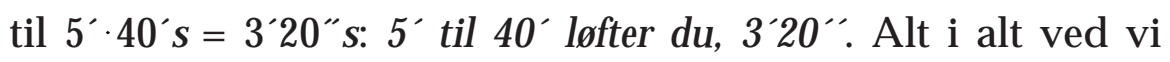
dermed, at

$$
1^{\circ} 26^{\prime} 40^{\prime \prime} \square(s)+2 \cdot 3^{\prime} 20^{\prime \prime} s=25^{\prime} \text {. }
$$

Med denne ligning støder vi ind i et problem, som den babyloniske beregner allerede har opdaget $i$ linie 2, og som har fået ham til at udskyde udregningen af vingerne et øjeblik: Udtrykt i moderne terminologi er ligningen ikke-normaliseret, d.v.s., koefficienten til andengradsleddet er ikke 1. Fra det babyloniske synspunkt er problemet at antallet af kvadratarealer afviger fra 1 - jfr. Figur 18 øverst, hvor vi har en sum af $\alpha$ kvadratarealer (et skraveret rektangel $\llcorner\sqsupset(s, \alpha s)$ ) og $\beta$ sider (et skygget rektangel

\footnotetext{
${ }^{13}$ Det er denne omhyggelige beregning der viser at der faktisk er tale om et $n y t$ kvadrat $\square(s)$, og ikke blot en omregning af $\square\left(s_{2}\right)$ udtrykt ved $s_{1}$ og $\square\left(s_{1}\right)$.
} 
$\sqsubset \neg(s, \beta))$; i det nærværende tilfælde er $\alpha=1^{\circ} 26^{\prime} 40^{\prime \prime}$, og $\beta=2 \cdot 3^{\prime 2} 20^{\prime \prime}$. Det betyder at vi ikke umiddelbart kan bruge den normale klippe-klistreprocedure: hvis vi brækker den $y$ derste halvdel af fremspringet $\sqsubset \neg(s, \beta)$ og klister det på for neden, får vi ikke et gnomon.

Babylonierne klarede problemet ved hjælp af det kunstgreb der vises nederst i Figur 18: Skalaen ændres i lodret retning, så siden i stedet for $s$ bliver $\alpha s$; summen af de to arealer er så ikke længere $25^{\prime}$ men $\alpha \cdot 25^{\prime}=$

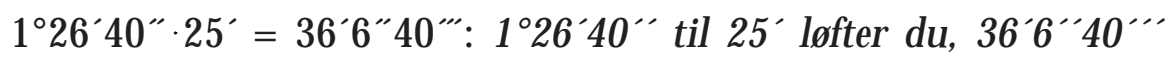
indskriver $d u$. Som vi bemærker forandres antallet $\beta$ af kvadratsider ikke ved transformationen, derimod ændres siden selv fra $s$ til $\alpha s .{ }^{[14]}$

I moderne formelsprog svarer det til at ligningen

$$
\alpha s^{2}+\beta s=\Sigma
$$

\footnotetext{
${ }^{14}$ Dette kunstgreb er fast kost ved løsningen af ikke-normaliserede problemer, og vi behøver ikke at forestille os at babylonierne normalt har tegnet noget svarende til Figur 18. De har sagtens kunnet nøjes med at forestille sig en ændring i målestokken i den ene retning - vi ved fra andre tekster at de tegninger de lavede kunne være grove strukturdiagrammer, lige netop nok til at støtte tanken. Derfor behøvede de blot at multiplicere summen $\Sigma$ med $\alpha$, og kunne gøre det før de fandt $\beta$.
} 
multipliceres med $\alpha$ på begge sider af lighedstegnet og derved bliver til en normaliseret ligning med ubekendt $\alpha s$ :

$$
(\alpha s)^{2}+\beta \cdot(\alpha s)=\alpha \Sigma,
$$

som er af samme type som BM $13901 \mathrm{nr}$. 1. Vi er dermed kommet så langt at vi kan bruge det sædvanlige kneb, nemlig at brække det skyggede rektangel over og lade de to dele som ben i et gnomon »holde" det kvadratiske komplement (se Figur 19; den yderste del er prikket hvor den flyttes fra og skraveret hvor den flyttes hen). $\mathrm{Nu}$, og først nu, er beregneren tvunget til at udregne hvor mange sider der er

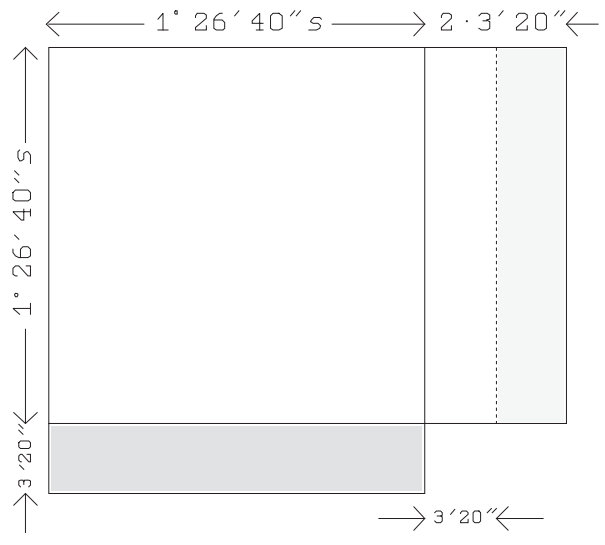

Figur 19. BM 13901 nr. 14, det normaliserede problem. i det skyggede rektangel fra Figur 18 (altså at finde $\beta$ ). Hver »vinge« bidrager som sagt med $5^{\prime} \cdot 40^{\prime}=3^{\prime} 20^{\prime \prime}$. Hvis han havde arbejdet efter mekaniske procedurer ville han nu have fundet $\beta$ ved at gange med 2 . Det gør han ikke, for han ved at de to »vinger « tilsammen udgør det fremspring, hvor halvparten skal brækkes af. Han kan derfor med det samme lade 3'20" og 3'20" »holde " det kompletterende kvadrat og føje det resulterende areal $11^{\prime \prime} 66^{\prime \prime} 40^{\prime \prime \prime}$ til gnomonarealet 36'6"40": 3'20" og 3'20" lader du holde, 11" 6" "40"'" til $36^{\prime} 6^{\prime \prime} 40^{\prime \prime \prime}$ tilføjer du: $36^{\prime} 17^{\prime \prime} 46^{\prime \prime \prime} 40^{\prime \prime \prime \prime}$. 
$36^{\prime} 17^{\prime \prime} 46^{\prime \prime} 40^{\prime \prime \prime \prime}$ er arealet af det kompletterede kvadrat, hvis side derfor er $\sqrt{36^{\prime} 17^{\prime \prime} 46^{\prime \prime \prime} 40^{\prime \prime \prime \prime}}=46^{\prime} 40^{\prime \prime}: 36^{\prime} 17^{\prime \prime} 46^{\prime \prime \prime} 40^{\prime \prime \prime \prime}$

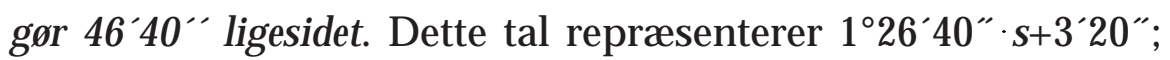

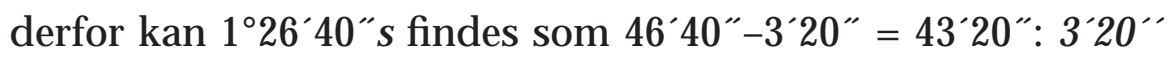
som du har ladet holde fra det indvendige af 46 $40^{\prime \prime}$ udriver du. 43'20" indskriver $d u$. Næste trin består i at finde s selv. $1^{\circ} 26^{\prime} 40^{\prime \prime}$ er irregulær, men kvotienten ${ }^{46^{\circ} 40^{\prime \prime}} / 1^{\circ} 26^{4} 40^{\prime \prime}$ opgives (med et sumerisk låneord der måske betyder »det der skal stilles ved siden af «)

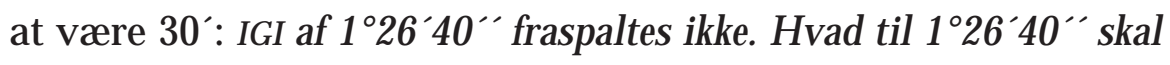
jeg sætte som 43'20" giver mig? 30' er dets bandûm. Til sidst findes $s_{1}$ og $s_{2}$ som henholdsvis $1 \cdot s=30^{-[15]}$ og $40^{\prime} \cdot s+5^{\prime}=25^{\prime}$ : 30' til 1 løfter du: 30' er den første modstilling. 30' til 40' løfter du: 20', og 5 tilføjer du: 25' er den anden modstilling. Dermed er opgaven løst.

\section{TMS IX nr. 1 og 2}

Nr. 1

1. Fladen og 1 længde lagt i bunke, 40’. 30', længden', 20’, bredden.

2. Når 1 længde til 10', fladen, er blevet tilføjet,

3. eller 1, (som) sokkel, til 20', bredden, er blevet tilføjet,

4. eller $1^{\circ} 20^{\prime}$ 'er blevet sat' til bredden der sammen med $30^{\prime}$, længden, 'holder? 40',

5. eller $1^{\circ} 20^{\prime}$ sammen med $30^{\prime}$, længden, holder, $40^{\prime}$ er dets navn.

\footnotetext{
${ }^{15}$ At $s_{1}$ findes som $1 \cdot s$ bekræfter endnu engang at vi har arbejdet med en $n y$ side $s$.
} 
6. Eftersom således, til 20', bredden, som det er blevet sagt dig,

7. 1 er blevet tilføjet: $1^{\circ} 20^{\prime}$ ser du. Herudfra

8. spørger du. $40^{\prime}$ er fladen, $1^{\circ} 20$ bredden, længden hvad?

9. 30` er længden. Således er fremgangsmåden.

Nr. 2

10. Flade, længde og bredde lagt i bunke, 1. Ved den akkadiske (metode).

11. 1 til længden tilføj. 1 til bredden tilføj. Eftersom 1 til længden er tilføjet,

12. 1 til bredden er tilføjet, 1 og 1 lad holde, 1 ser du.

13. 1 til bunken af længde, bredde og flade tilføj, 2 ser du.

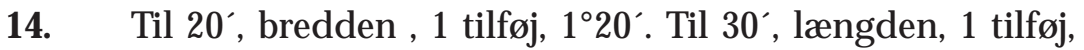
$1^{\circ} 30^{\prime}$.

15. 'Eftersom? en flade, den med $1^{\circ} 20^{\prime}$ som bredde, med $1^{\circ} 30^{\prime}$ som længde,

16. 'længden? sammen med bredden holder, hvad er dens navn?

17. 2, fladen.

18. Således den akkadiske (fremgangsmåde).

Nr. 1 og 2 af denne tekst løser ingen opgave, i stedet giver de en pædagogisk forklaring af hvordan summen af areal og sider skal forstås og behandles. Teksten starter med at forklare to forskellige situationer: når summen af et rektangels areal og længden alene er kendt; og når summen af arealet og begge sider er kendt. I nr. 3 (som vi skal vende tilbage til i næste kapitel) stilles og løses så en egentlig opgave.

Figur 20 illustrerer tekstens forklaring på det første problem, det hvor summen af et rektangels areal og længden alene er kendt. Svarende til vores moderne omformning $l \cdot b+l=l \cdot b+l \cdot 1=$ 
$l \cdot(b+1)$ forlænges bredden med en »sokkel« (det er i hvert fald den rimeligste tolkning af et sumeriske udtryk der ikke kendes andetsteds fra, men som synes at betegne en ting som noget står vedvarende eller stabilt på). Der gives en række indbyrdes afhængige forklaringer, forbundet med »eller ... eller ... eller«, svarende til en udtryksmåde vi tit bruger når vi omformer en ligning: $» 2 a^{2}-4=4$, eller $2 a^{2}=4+4$, eller $a^{2}=4$, eller $a= \pm \sqrt{ } 4= \pm 2 \ll$.

Arealet omtales som 10' i linie 2; det

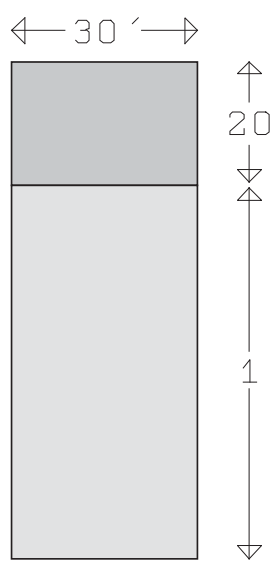

Figur 20. TMS IX, nr. 1. viser at både længde og bredde forudsættes at være kendte. Tavlen er beskadiget, og vi kan derfor ikke af den grund være sikre på at længden også udtrykkeligt er givet i linie 1 (denne skelnen mellem det givne og det blot kendte skal vi vende tilbage til adskillige gange i det følgende, bl.a. på side 108). Bredden er imidlertid givet, som vi kan se af linie 3, og igen i linie 6.

Til sidst vises i linie 6-9 hvorledes vi, hvis vi kender summen af areal og bredde, kan finde længden (ved en underforstået division).

Nr. 2 behandler den mere komplekse situation at summen af rektangelarealet og begge sider er kendt. Metoden illustreres i Figur 21: Længden og bredden forlænges hver med 1; det frembringer for det første to rektangler $\sqsubset \sqsupset(l, 1)$ og $\sqsubset \sqsupset(b, 1)$, der kan repræsentere længden og bredden; men herudover har vi et kvadratisk hjørne $\square(1,1)$, der tilføjes til det oprindelige areal. Dette areal 2 har længden $l+1\left(=1^{\circ} 30^{\prime}\right)$ og bredden $b+1\left(=1^{\circ} 20^{\prime}\right)$; 
efterkontrol viser at hvis vi lader disse to »holde«, får vi netop et areal 2.

Denne metode har et navn (hvad der er ganske usædvanligt i de matematiske tekster). Den hedder »den akkadiske«. Akkadisk er den fælles betegnelse for det sprog hvis hoveddialekter er babylonisk

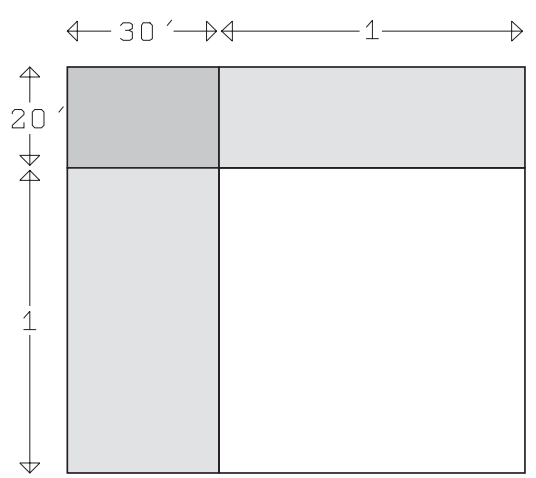

Figur 21. TMS IX, nr. 2. og assyrisk (se boxen »Lidt almen historie«), og er samtidig betegnelsen for den vigtigste ikke-sumeriske befolkningsgruppe i det 3. årtusinde f.v.t.; meget (bl.a. netop denne tekst) tyder på skriverskolen har lånt inspirationen til sin algebra fra akkadiske landmålere (det er et emne skal vi vende tilbage til på side 117). Metoden er jo intet andet end den kvadratiske komplettering, som er grundlaget for al løsning af andengradsligninger (hvad enten det sker geometrisk eller, som hos os, i en tal-algebra); og det er altså netop denne kerne $i$ algebraen der synes at bære navnet »den akkadiske [fremgangsmåde]«. 


\section{KOMPLEKSE ANDENGRADSOPGAVER}

Vi har hidtil set på de metoder ved hvis hjælp de babyloniske regnere løste de grundlæggende andengradsopgaver. Men selve begrebet »de grundlæggende « røber at de også arbejdede med andre, adskilligt mere komplekse problemer. De er emnet for dette kapitel, der lægger ud med den tredje opgave fra den tavle hvis pædagogiske indledning vi netop har betragtet.

\section{TMS IX nr. 3}

19. Flade, længde og bredde lagt i bunke, 1 er fladen. 3 længder, 4 bredder lagt i bunke,

20. dets 17.-del til bredden tilføjet, 30'.

21. Du, 30’ til 17 gå: 8०30’ ser du.

22. til 17 bredder, 4 bredder tilføj, 21 ser du.

23. 21, så meget som der er af bredder, sæt. 3, fra tre længder,

24. 3, så meget som der er af længder, sæt. $8^{\circ} 30$, hvad er dets navn?

25. 3 længder og 21 bredder lagt $\mathrm{i}$ bunke.

26. $\quad 8^{\circ} 30^{\prime}$ ser du.

27. 3 længder og 21 bredder lagt i bunke.

28. Eftersom 1 til længden er tilføjet og 1 til bredden er tilføjet, lad dem holde:

29. 1 til bunken af flade, længde og bredde tilføj, 2 ser du,

30. 2, fladen. Siden længden og bredden af 2, fladen,

31. $1^{\circ} 30^{\prime}$, længden, sammen med $1^{\circ} 20^{\prime}$, bredden lades holde,

32. 1 den tilføjede til længden og 1 den tilføjede til bredden,

33. lad holde, ${ }^{i} 1$ ser du? 1 og 1 , det sammendyngede, læg $\mathrm{i}$ 
bunke, 2 ser du.

34. $3\left({ }^{i} \ldots{ }^{3}\right), 21\left({ }^{(} \ldots{ }^{3}\right)$ og $8^{\circ} 30^{\prime}$ læg i bunke, $32^{\circ} 30^{\prime}$ ser du.

35. Således spørger du.

36. $\ldots$ af bredder, til 21, i bunke:

37. ... til 3, længder, løft,

38. $1 ` 3$ ser du. $1 ` 3$ til 2 , fladen, løft:

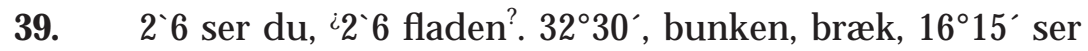
du.

40. $16^{\circ} 15^{\prime}$, modstykket, sæt, lad holde,

41. $44^{\circ} 23^{\circ} 45^{\prime \prime}$ ser du. $2 \times 6$

42. fra $44^{\prime} 24^{\circ} 3^{\prime} 45^{\prime \prime}$ udriv, $2^{\prime} 18^{\circ} 3^{\prime} 45^{\prime \prime}$ ser du.

43. Hvad bliver gjort ligesidet? $11^{\circ} 45^{\prime}$ bliver gjort ligesidet, $11^{\circ} 45^{\prime}$ til $16^{\circ} 15^{\prime}$ tilføj,

44. 28 ser du. Fra den 2 den udriv, $4^{\circ} 30^{\prime}$ ser du.

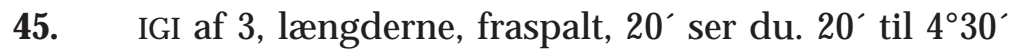

46. løft: $1^{\circ} 30^{\prime}$ ser du,

47. $\quad 1^{\circ} 30^{\prime}$ er længden af 2, fladen. Hvad til 21, bredderne, skal jeg sætte

48. Som 28 giver mig? $1^{\circ} 20^{\prime}$ sæt, $1^{\circ} 20$ er bredden

49. af 2 , fladen. Vend tilbage. 1 fra $1^{\circ} 30^{\prime}$ udriv,

50. $30^{\prime}$ ser du. 1 fra $1^{\circ} 20^{\prime}$ udriv,

51. $20^{\prime}$ ser du.

Der er tale om et system af to ligninger omhandlende et rektangel og dets sider, én af første og én af anden grad. Den første er i samme stil som ligningerne fra TMS XVI og VII (hhv. side 27 og 36). Den anden kender vi fra nr. 2 af den nærværende tekst (side 60). Systemet kan oversættes til

$$
\sqsubset \sqsupset(l, b)+l+b=1, \quad 1 / 17(3 l+4 b)+b=30^{\prime} .
$$

Som vi har set det før, løftes der til 17, så vi får heltallige koefficienter (»så meget som der er«) i førstegradsligningen: 


$$
3 l+(4+17) b=3 l+21 b=17 \cdot 30^{\prime}=8^{\circ} 30^{\prime} .
$$

Beregningen foretages i linie 21-25, mens linie 26-27 opsummerer resultatet.

I linie 28-30 gentages tricket fra tekstens del 2 (se Figur 21): Længden og bredden forlænges med 1 , og det kvadrat der opstår når de to »tilføjede « ${ }^{[16]} »$ holder« tilføjes til »bunken« $\sqsubset \sqsupset(l, b)+l+b$; resultatet er et »areal $2 «$, hvis mening forklares igen i linie 30-33.

Linie 34-37 er stærkt beskadiget, og det er ikke muligt at rekonstruere teksten fuldstændigt. Der er dog ingen tvivl om hvad der alt $i$ alt foregår. Vi kan indføre betegnelserne $\lambda=l+1$ og $\beta=b+1$ - teksten taler om størrelserne som længde og bredde »af fladen 2 «. Med andre ord er altså $\sqsubset \sqsupset(\lambda, \beta)=2$. Samtidig er

$3 \lambda+21 \beta=3 \cdot(l+1)+21 \cdot(b+1)=3+21+3 l+21 b=3+21+8^{\circ} 30^{\prime}=$ $32^{\circ} 30^{\prime}$.

Nu gentages tricket fra den ikke-normaliserede ligning i BM 13901 nr. 14 (se side 57). For ikke at tabe overblikket kan vi indføre betegnelserne $L=3 \lambda, B=21 \beta$ (blot skal vi være klar over at vores tekst ikke har noget særskilt navn for disse størrelser, således som den har for $\lambda$ og $\beta$ ). I linie 36-39 udregnes $\sqsubset \neg(L, B)=$ $(21 \cdot 3) \cdot 2=1 ` 3 \cdot 2=2 ` 6$, så vi har

$$
L+B=32^{\circ} 30^{\prime}, \quad \sqsubset \exists(L, B)=26^{\prime} .
$$

${ }^{16}$ Ligesom »tilføjelsen « på side 36 afledt fra »at tilføje«, men et andet ord; af samme grund oversat lidt anderledes.

På tysk ville de to ord kunne gengives som hhv. das Hinzuzufügende (»tilføjelsen«, egl. »det der skal tilføjes«) og das Hinzugefügte (»det tilføjede $\ll)$. 
Der er vi nået til i linie 39, og dermed er vi kommet frem til et standardproblem som vi ikke har mødt endnu: et rektangel, hvor vi kender arealet og summen af siderne.

Metoden er igen en klippeklistre-metode, jfr. Figur 22. Vi brækker endnu engang den længde vi kender, altså summen af $L$ og $B$. Dette er det

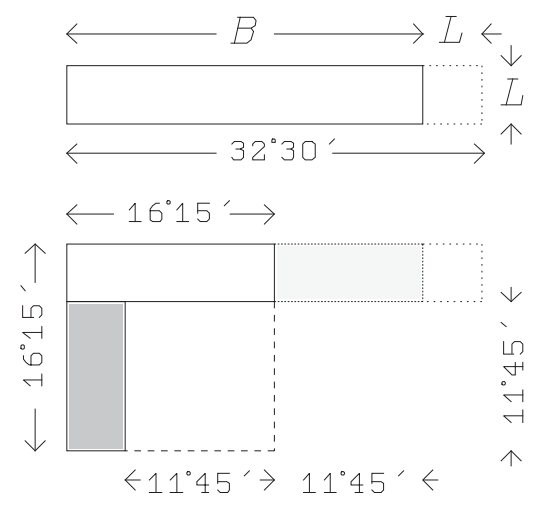

Figur 22. Klippe-klistre-metoden i TMS IX, del 3. fuldt optrukne rektangel $\sqsubset \exists(L, B)$ forlænget med det let punkterede kvadrat $\square(L)$ yderst til højre. Dernæst lader vi de to dele »holde« (linie 39-40). På figuren er endnu engang det areal der klippes af prikket, mens det skraverede areal viser hvor det klistres på.

Én del af det »holdte « kvadrat $\square\left(16^{\circ} 15^{\prime}\right)$ udgøres af et gnomon hvis areal vi kender - det er nemlig en omlægning af vores rektangel $\sqsubset \sqsupset(L, B)$. Samtidig kender vi hele arealet - det er jo $16^{\circ} 15^{\prime} \times 16^{\circ} 15=4^{\prime} 24^{\circ} 3^{\prime} 45^{\prime \prime}$ (linie 40-41). Når vort gnomonareal rives ud (linie 41-42), har vi dermed for det kompletterende kvadrat et areal $2{ }^{\prime} 18^{\circ} 3^{\prime} 45^{\prime \prime}$. Dets sidelængde (»det der bliver gjort ligesidet «) er derfor $11^{\circ} 45^{\prime}$, der skal fjernes fra det ene eksemplar af $16^{\circ} 15^{\prime}$ (hvorved vi får $L$ ) og lægges til det andet (hvorved vi får B); da det imidlertid ikke denne gang er det samme stykke der skal fjernes og lægges til, tilføjes der før der udrives, mens det omvendte var tilfældet i YBC 6967 (side 51). I linie 44 findes $L=4^{\circ} 30^{\prime} \operatorname{og} B=28$. Resten af teksten finder $l \operatorname{og} b-$ vi husker at $L=3 \lambda, \lambda=l+1, B=21 \beta, \beta=b+1$. Da 28 ikke har 
nogen IGI oplyses det i linie 48 at $211^{\circ} 20^{\prime}=28$.

\section{AO 8862 nr. 2}

I

30. Længde, bredde. Længde og bredde

31. har jeg ladet holde, en flade har jeg bygget.

32. Jeg gik rundt om den. Halvdelen af længden

33. og tredjedelen af bredden

34. til det indvendige af min flade

35. har jeg tilføjet: 15 .

36. Jeg vendte tilbage. Længde og bredde

37. har jeg lagt i bunke: 7 .

II

1. Længde og bredde hvad?

2. Du, ved din metode,

3. 2 (som) indskrivning af halvdelen

4. $\quad$ og 3 (som) indskrivning

5. af tredjedelen indskriver du:

6. IGI af $2,30^{\prime}$, fraspalter du:

7. $30^{\prime}$ skridt på 7, $3^{\circ} 30^{\prime} ;$ til 7 ,

8. de sammenbunkede, længde og bredde,

9. bringer jeg:

10. $3^{\circ} 30^{\prime}$ fra 15 , mine sammenbunkede,

11. skær af:

12. $11^{\circ} 30^{\prime}$ er resten.

13. Gå ikke videre. Lad 2 og 3 holde:

14. 3 skridt på 2,6 .

15. IGI af 6, 10' giver det dig.

16. $10^{\prime}$ fra 7 , dine sammenbunkede,

17. længde og bredde, udriver jeg: 
18. $6^{\circ} 50^{\prime}$ er resten.

19. Dets halvpart, af $6^{\circ} 50^{\prime}$, brækker jeg:

20. $3^{\circ} 25^{\prime}$ giver det dig.

21. $3^{\circ} 25^{\prime}$ indtil to gange

22. indskriver du; $3^{\circ} 25^{\prime}$ skridt på $3^{\circ} 25^{\prime}$,

23. 11 $10^{\circ} 25^{\prime \prime}$; fra det indvendige

24. $11^{\circ} 30^{\prime}$ udriver jeg:

25. $10^{\prime} 25^{\prime \prime}$ er resten. 〈10`25" gør 25' ligesidet.

26. Til det første $3^{\circ} 25^{\prime}$

27. 25' tilføjer du: $3^{\circ} 50^{\prime}$,

28. og det som fra de sammenbunkede

29. af længde og bredde jeg har udrevet

30. til $3^{\circ} 50$ tilføjer du:

31. 4 er længden. Fra det andet $3^{\circ} 25^{\prime}$

32. $25^{\prime}$ udriver jeg: 3 er bredden.

32a. 7 er de sammenbunkede.

32b. 4, længden

3 , bredden

12 , fladen

Opgaven fortæller i sin første linie at handle om en figur der karakteriseres til fulde ved sin længde og bredde - altså om et rektangel (jfr. side 28), eller snarere en rektangulær mark; landmålingsreferencerne er jo ikke til at tage fejl af.

Før vi ser på proceduren er nogle træk i formuleringen værd at fremhæve. Vi ser i starten at det at lade længde og bredde »holde« ikke fører til et tal men derimod til at en »flade« er blevet bygget eller afmærket i terrænet. Senere, når to liniestykker holder (linie II.13; jfr. også linie II.21-22), ser vi også at beregningen af det holdte rektangel er en proces for sig, der beskrives med multiplikationstabellens ord. Endelig er det værd at lægge mærke til at summen ved en bunkelægning omtales som flerheden af 
de sammenbunkede størrelser. Da teksten af forskellige grunde må regnes blandt de ældste, kan disse særheder formodes at fortælle os om den oprindelige tankegang bag den babyloniske algebra - en tankegang som det kan være sværere at læse ud af tekster hvis sprogbrug er blevet standardiseret.

Opgaven handler altså om et rektangel. I linie I.36-37 får vi at vide at bunken af længde og bredde er 7, og i I.32-35 at tilføjelse af den halve længde og en tredjedel af bredden til arealet giver $15::^{[17]}$

$$
\sqsubset \sqsupset(l, b)+\frac{1}{2} l+\frac{1}{3} b=15, \quad l+b=7 .
$$

Den øverste del af Figur 23 viser situationen, med 2 og 3 »indskrevet som indskrivning " af henholdsvis $1 / 2$ og $1 / 3$ af fremspringene 1 ved længden og bredden i linie II.2-5; den fuldt optrukne figur har altså arealet 15 .

Løsningen kunne have fulgt mønsteret fra den foregående opgave (TMS IX nr. 3). Hvis vi indfører en »forlænget længde« $\lambda=l+1 / 3$ og en »forlænget bredde $\beta=b+1 / 2$ og i overensstem-

\footnotetext{
${ }^{17}$ Vi bemærker at halvdelen her står som en brøkdel på linie med f. eks. tredjedelen. Den betegnes da også med en anden glose end halvparten, og findes ved multiplikation med 30', ikke ved brækning.

Vi bemærker også at halvdelen af længden og tredjedelen af bredden »tilføjes « til fladen og ikke »lægges i bunke« med den; det samme sker i enkelte andre af de tidligste tekster. Det ser ud til at landmålertraditionen har regnet med at linier kunne forstås som striber med bredde 1 (det er et forhold der kendes i en del andre praktiske landmålertraditioner, og som svare meget godt til at babylonierne regnede med at flader kunne forstås som skiver med tykkelse 1 KUŠ). Brugen af et »fremspring « der forvandler en linie til en stribe med areal er rimeligvis et raffinement som indføres i skolen.
} 
melse med »den akkadiske metode« tilføjer det manglende rektangel $\sqsubset \sqsupset(1 / 2,1 / 3)$ i hjørnet hvor 2 og 3 er »indskrevet", reducerer vi igen problemet til standardtypen

$\sqsubset \sqsupset(\lambda, \beta)=15+\sqsubset \sqsupset(1 / 2,1 / 3)=15^{\circ} 10^{\prime}$ ， $\lambda+\beta=7+\frac{1}{2}+\frac{1}{3}=7^{\circ} 50^{\prime}$.

Sådan bærer den nærværende tekst sig imidlertid ikke ad - den babyloniske algebra var et fleksibelt redskab og ikke en samling standardopskrifter som blev fulgt slavisk. Teksten beregner halvdelen af $7 \mathrm{og}$ »bringer « resultatet $3^{\circ} 30^{\prime}$ hen til »de

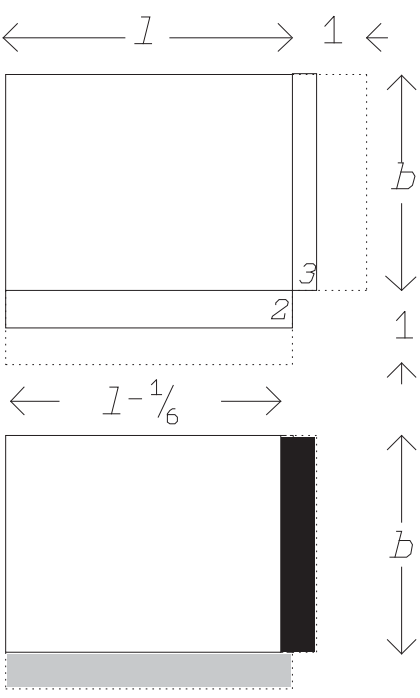

Figur 23. Reduktionen af AO 8862 nr. 2. sammenbunkede, længde og bredde«. Der er ikke tale om nogen form for regneoperation - den kommer først bagefter. Det er derimod tale om at et rektangel $\sqsubset \sqsupset(l+b, 1 / 2)$ fysisk flyttes hen hvor længde og bredde (udstyret med bredder $1 / 2$ og $1 / 3$ ) befinder sig. På den måde bliver det muligt at skære rektanglet $\sqsubset \sqsupset(l+b, 1 / 2)$ ud (så længe det befinder sig et andet sted ville dette være meningsløst). I den nederste del af Figur 23 er det område de skæres bort skraveret; den uskraverede rest bliver $11^{\circ} 30^{\prime}$. I den proces er den tillagte halve længde blevet elimineret; samtidig er der imidlertid forsvundet mere end den tredjedel af længden der indgik i de 15.

Hvor meget mere?

Det ville være simpelt at subtrahere 20' $(=1 / 3)$ fra 30' $(=1 / 2)$, men det er åbenbart ikke informativt nok (med mindre 
der er tale om en reminiscens fra før algebraen blev integreret $i$ en undervisning hvor man var vel trænet $i$ brug af trestalssystemet); i hvert fald foretages der i stedet et sidespring, markeret ved vendingen "gå ikke videre«: Der konstrueres et rektangel

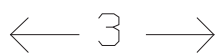
$\sqsubset \sqsupset(3,2)$, og uden yderligere argument ses

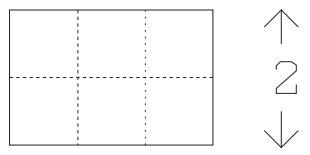

Figur 24. det at halvdelen overstiger tredjedelen med ét lille kvadrat ud af seks (se Figur 24 - igen et argument af typen »simpel falsk ansats $\ll$ ).

Hermed ved vi at vi ud over tredjedelen af bredden har fjernet et stykke $\sqsubset \exists\left(b, 10^{\prime}\right)$; sætter vi $\lambda=l-10^{\prime}$, er derfor

$$
\lambda+b=7-10^{\prime}=6^{\circ} 50^{\prime}, \quad \sqsubset \sqsupset(\lambda, b)=11^{\circ} 30^{\prime} .
$$

Endnu engang har vi altså et rektangel hvor vi kender summen af længde og bredde samt arealet, og vi løser problemet på samme måde som det blev gjort i TMS IX nr. 3 - se Figur 25; endnu engang er det areal der klippes af

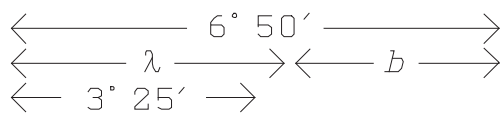
prikket, og på det sted hvor det flyttes hen vises det skraveret. Den eneste forskel i forhold til TMS IX nr. 3 er at de to halvparter »indskrives « $i$ stedet for at man lader dem »holde« - men igen som forudsætning for en påfølgende multiplikation, så meningen må være den sædvanlige rektangelkonstruktion (sml. linie II.13-14). 
Vi bemærker at den sluttelige addition af siden i det kompletterende kvadrat kommer før subtraktionen, som i TMS XI nr. 3. Heller ikke i dette tilfælde er der tale om at en figurdel flyttes og derfor må udrives før den kan tilføjes.

VAT 7532

Fs

1. Et trapez. Et afskåret rør har jeg taget som målerør. Mens det var helt

2. 1 skok (skridt)

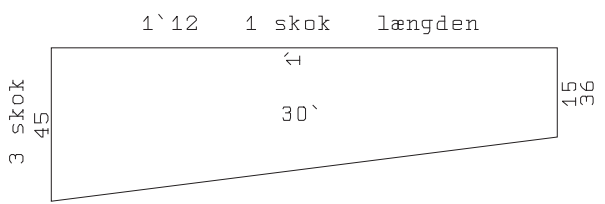

Figur 26. Den ledsagende figur fra langs længden gik jeg. Dets 6.-del

VAT 7532. „Øvre bredde« til venstre.

3. knækkede af for mig: 1`12 (skridt) vedføjede jeg længden.

4. Igen, 3.-delen og $1 / 3$ KUŠ knækkede af for mig.

5. Med 3 skok (skridt) den øvre bredde gik jeg.

6. Det som (sidst) knækkede af for mig har jeg sat tilbage på røret:

7. 36 (skridt) langs (den nedre) bredde gik jeg. Fladen er en BUR. Rørets begyndelse (d.v.s. oprindelige længde) hvad?

8. Du, ved din metode, for røret som du ikke kender,

9. 1 sæt. Dets 6.-del knæk af, 50’ efterlader du.

10. IGI af $50^{\prime}$ fraspalt, $1^{\circ} 12^{\prime}$ til 1 skok løft:

11. $1 ` 12$ til $1 ` 12$ tilføj: 2 24 som falsk længde giver det.

12. For røret som du ikke kender, 1 sæt. Dets 3.-del knæk af,

13. 40' til den øvre breddes 3 skok løft:

14. 2 giver det. 2 og 36 , den nedre bredde, læg i bunke,

15. $2 ` 36$ til 2`24, den falske længde, løft, 6`14`24 er den falske 
flade.

16. Fladen til 2 gentag, 1 “ til 6“ 14 '24 løft,

17. $\quad 6$ '“' 14 “' 24 ” giver det; og $1 / 3$ KUŠ som knækkede af

18. til 3 skok løft. 5 til $2 ` 24$, den falske længde,

19. løft: 12 . $1 / 2$ af 12 bræk, 6 lad støde sammen (med sig selv).

Bs

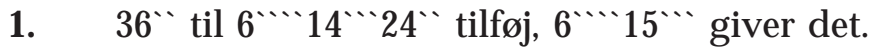

2. $\quad 6$ '“'15 15 gør $2 “ 30$ ligesidet. 6` som du lod tilbage

3. til 2 ' 30 tilføj, 2 ' 36 'giver det. IGI af 6 “' 14 '24,

4. den falske flade, fraspaltes ikke. Hvad til 6“'14'24

5. $\quad$ skal jeg sætte som 2' 36 ' giver? 25' sæt.

6. Siden 6.-delen af begyndelsen knækkede af,

7. 6 indskriv, 1 fjern, 5 lader du tilbage.

〈IGI af 5 fraspalt, 12' giver det. 12' løft til 25, 5' giver det.>

8. $5^{\prime}$ til $25^{\prime}$ tilføj, $1 / 2$ NINDAN som rørets begyndelse giver det.

Også denne opgave handler om en mark - men unægtelig om en situation fra landmålernes eventyrland. »Virkeligheden« kommer ind ved at der foretages en måling, og ved at den foregår med et afskåret sivrør (der sikkert også har haft let ved at knække i virkeligheden); også rørets længde - 1/2 NINDAN - falder sammen med den måleenhed »et rør« som oftest brugtes i praktisk måling. Endelig viser brugen af talordet for 60 (på dansk »en skok«) ét af midlerne til at undgå positionssystemets flertydighed.

Men resten - fra den omstændighed at markens areal er kendt til den måde de afbrækkede stykkers længde opgives på viser kun hvilke kunstgreb man måtte gribe til for at producere andengradsopgaver. Til gengæld er der virkelig tale om en raffineret opgave. 
Figur 26 gengiver for en gangs skyld en tegning på lertavlen selv. Generelt indeholder tavlerne kun tegninger der er med til at definere problemet, aldrig figurer der viser metoden. Til gengæld er Figur 26 et eksempel på det allerede omtalte forhold, at løsningen er kendt allerede inden opgaven løses, idet tallene 1`, 45 og 15 er de pågældende siders længde i NINDAN.

Situationen er altså at vi starter opmålingen af trapezet med et rør af ukendt begyndelseslængde $R$. Vi når at afskridte 1 rørlængder (1 skok = 60) langs markens længde (Fs 1-2), inden røret knækker og reduceres til $r=5 / 6 R$; resten af længden er så $1 ` 12 r$ (Fs2-3).

Så knækker røret igen. I Fs 4-5 måles den »øvre [d.v.s. venstre] bredde ${ }^{[18]}$ til $3{ }^{\prime} z$, hvor $z=2 / 3 r-1 / 3$ KUŠ er den nye rørlængde.

Det stykke som sidst knækkede af sættes på igen, og den nedre bredde måles i Fs 7 til 36 rørlængder med røret $r$. Endelig ved vi altså at markens areal er 1 BUR $=30^{\circ}$ SAR $(1$ SAR $=1$ NINDAN $^{2}$, jfr. side 16). Opgaven er at bestemme det oprindelige rørs længde.

I Fs 9-11 omregnes længden til enheder $r$ ved hjælp af en falsk ansats: hvis $R$ havde været 1 , så er $r$ kun 50', og $R$ dermed

\footnotetext{
${ }^{18}$ At den »øvre« bredde ligger til venstre i tegningen har at gøre med den drejning af skriftens retning der omtales i boxen »Kileskriften«. Det antages at drejningen i daglig brug på lertavlerne allerede havde fundet sted i den oldbabyloniske tid, så man skrev fra venstre mod højre; under alle omstændigheder vidste man stadig hvad der i princippet var opad, for til højtidelig brug (officielle indskrifter i sten) skrev man stadig oppefra og nedefter.
} 
selv IGI af $50^{\prime}=1^{\circ} 12^{\prime} \cdot r$. De 1 skridt på $R$ bliver altså $1 ` 12 \cdot r$, og hele længden $1 ` 12 \cdot r+1 ` 12 \cdot r=2 ` 24 \cdot r$. Størrelsen $2 ` 24$ omtales i teksten som »den falske længde«, altså længden udtrykt i enheden $r$.

I Fs 12 kommer der en

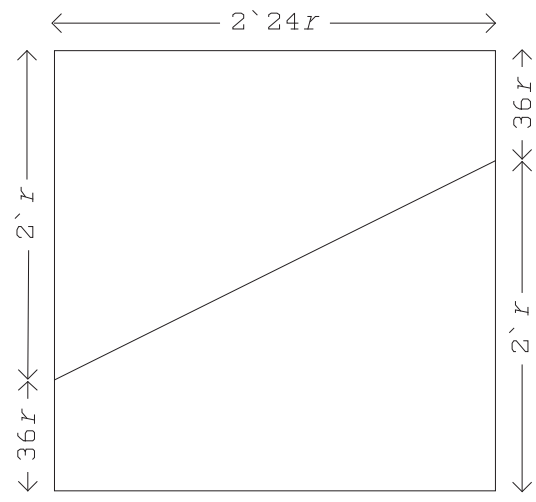
ny falsk ansats. Teksten sætter det én gang knækkede rørs længde $r$ til 1, og finder det med $1 / 3$ reducerede rør som 40’. Hvis vi ser bort fra det yderligere tab på $1 / 3$ KUŠ, bliver den øvre falske bredde (bredden målt i enheden $r$ ) altså 40' gange 3 skok $=40^{\prime} \cdot 3^{\prime}=2^{\prime}$. Vi kan også siges at den øvre bredde er $2 \nmid r$ - stadig under

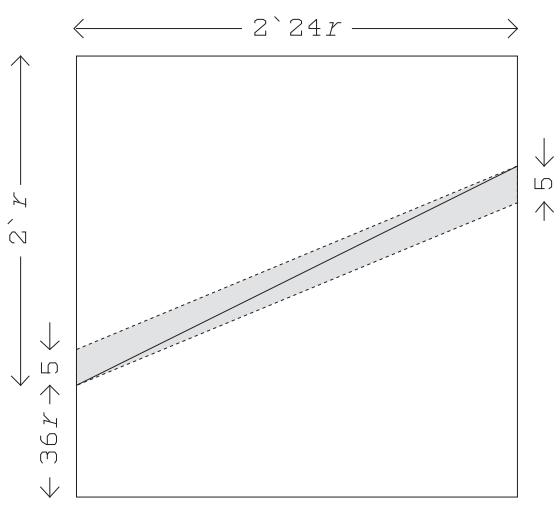

Figur 27. Det fordoblede trapez fra VAT 7532. forudsætning af at vi ser bort fra den manglende stump på $1 / 3 \mathrm{KUŠ}$.

Da Fs 7 fortæller os at den nedre falske bredde er 36, kender vi nu - med samme forbehold - de tre sider der skal til for at bestemme trapezets areal udtrykt i enheden $\square(r)$.

Men dette areal bestemmes ikke. I stedet fordobles det til et rektangel, som vi kan se øverst i Figur 27. I Fs 14-16 beregnes arealet af dette rektangel (den »falske flade«) til 6“ 14 `24, i den underforståede enhed $\square(r)$. 
Hvis ikke røret under måling af den øvre bredde havde manglet stykket på $1 / 3$ KUŠ, kunne vi nu have klaret opgaven med en simpel falsk ansats, svarende til hvad der skete i BM $13901 \mathrm{nr} .10$ (se side 52); markens areal fortælles jo i Fs 7 at være 1 BUR, så det dobbelte areal er 2 BUR $=1$ " $\operatorname{NINDAN}^{2}$ (Fs 16: Fladen til 2 gentag, 1“). Men så nemt går det ikke her: for hvert af de 3 skridt vi tog med det to gange forkortede rør mangler der jo $1 / 3$ KUŠ, i alt altså $3 \cdot 1 \frac{1}{3}$ KUŠ $=1$ KUŠ $=5$ NINDAN ( 1 KUŠ $=$ $1 / 12$ NINDAN): $1 / 3$ KUŠ som knækkede af til 3 skok løft. 5 (Fs 17-18). Den virkelige marks fordoblede areal er derfor ikke det rektangel der vises i den øverste del af Figur 27 men det der bliver tilbage når vi fjerner den skyggede stribe, som vist nederst i figuren. Denne stribes areal er 5'2'24r = 12`r: 5 til 2`24, den falske længde, løft: 12`. Sammenhængen mellem det »falske« areal og arealet af det dobbelte trapez i sandt mål kan nu udtrykkes i ligningen

$$
\text { 6“14`24 } \square(r)-12 ` r=1 \text { ” }
$$

Denne ikke-normaliserede ligning løser vi med det sædvanlige trick og multiplicerer altså med 6“14`24: Fladen til 2 gentag, 1 ” til 6“14 24 løft, 6“'”14 "'24" giver det (Fs 16-17). Derved fås en normaliseret ligning, hvor den ubekendte er 6“14 $24 r$ :

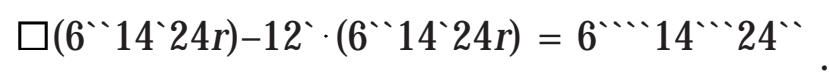

Proceduren til løsning af denne ligning er den samme som i BM 13901 nr. 2 (side 47). Udregningerne kan følges på Figur 28. Ligningens ubekendte 6“14 $24 r$ kan vi kalde $s$.

Arealet 6 '"'14"' 24 " svarer til det rektangel hvis længde (højde) er 6“14`24r, og hvis bredde er 6“14`24r-12`. Halvdelen af det hvormed længden overstiger bredden brækkes af og klistres 
på som vist på figuren (hvor det rektangel der brækkes af er prikket, og det skraverede rektangel viser hvor det klistres på). Konstruktionen af det kompletterende kvadrat beskrives med et af synonymerne for at »lade holde« eller »lade stå mod sig selv «, nemlig at »lade støde sammen«. Efter de sædvanlige trin finder vi i Bs 3 at $s=6$ "14 $24 r=2$ "36”, og i Bs

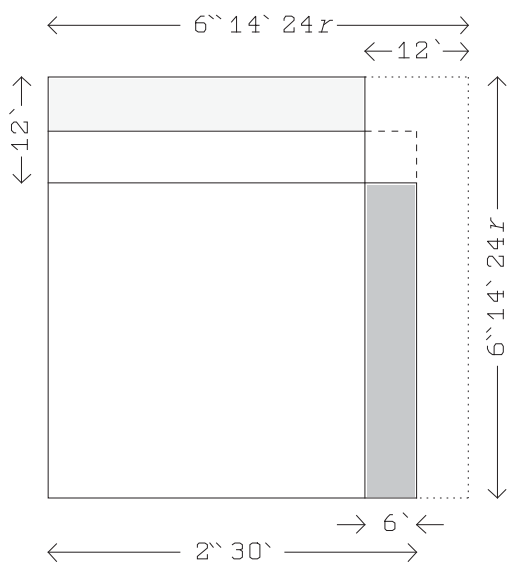

Figur 28.

5 at $r=25^{\prime}$. Vi bemærker dog at det skraverede stykke ikke til slut flyttes tilbage for at gendanne $s$ i lodret retning, men at $\mathrm{i}$ stedet det stykke på 6 `som i første omgang blev liggende nu flyttes ned til højre, så $s=6$ “14`24r=2“36` dannes i vandret retning: 6` som du lod tilbage til 2“30` tilføj, 2“36 giver det.

Bs 6-8 bruger en tredie falsk ansats: Hvis $R$ havde været 6 , ville $r$ være 5 . Forskellen 1 mellem $R$ og $r$ ses dermed at være $1 / 5$ af $r$ eller 12' gange $r$. Nu er den sande værdi af $r 2^{\prime}$; for at få $R$ skal vi hertil lægge $12^{\prime} \cdot 25^{\prime}=5^{\prime}$. Altså er $R=25^{\prime}+5^{\prime}=30^{\prime}=$ $1 / 2$ NINDAN.

Opgaven synes umiddelbart at have været populær blandt de babyloniske matematiklærere; den findes i adskillige eksemplarer, med varierende værdier af de givne størrelser. De har dog alle en række terminologiske særtræk til fælles - bl.a. brugen af ordtegnet for $1 / 2$ for »halvparten « og det forhold at resultater bliver "givet«, ikke »set«. De må derfor formodes alle at stamme fra samme lokalitet eller lokaltradition. En enklere variant (hvor 
marken er rektangulær og ikke trapezformet) genfindes i en tekst fra en anden lokalitet.

\section{TMS XIII ${ }^{[19]}$}

1. 2 GUR 2 PI 5 BÁN olie har jeg købt. Fra købet af hver šekel sølv

2. 4 sìlA olie har jeg skåret bort.

3. $2 / 3$ mina sølv som fortjeneste har jeg set. Svarende til hvad

4. har jeg købt og svarende til hvad har jeg solgt?

5. Du, 4 SìlA olie sæt, og 40, (af størrelsesorden som en) mina, fortjenesten, sæt.

6. IGI af 40 fraspalt, 1'30" ser du, 1'30" til 4 løft, 6’ ser du.

7. 6’ til 12`50 løft, 1`17 ser du.

8. $1 / 2$ af 4 bræk, 2 ser du, lad holde, 4 ser du.

9. 4 til $1 ` 17$ tilføj, 1`21 ser du. Hvad gøres ligesidet? 9 gøres ligesidet.

10. 9 modstykket sæt. $1 / 2$ af 4 som du har skåret bort bræk, 2 ser du.

11. 2 til det første 9 tilføj, 11 ser du; fra det andet udriv,

12. 7 ser du. 11 sìlA for hver šekel har du købt, 7 sìlA har du solgt.

13. Sølv svarende til hvad? Hvad skal jeg sætte til 11, sìlA,

${ }^{19}$ Denne opgave er ligesom TMS VII nr. 2 forholdsvis vanskelig. Skønt den er et interessant eksempel på en ikke-geometrisk anvendelse af den geometriske teknik, bør den som sagt i forordet udelades når bogen bruges i forbindelse med dækningen af matematikkens historiske aspekt, og antagelig også hvis bogen bruges som underlag for det valgfrie emne; den er medtaget som udfordring i forbindelse med udarbejdelse af en 3.-års opgave. 
14. Som $12 ` 50$, olien, giver mig. Sæt $1 ` 10,1$ mina 10 šekel sølv.

15. Ved 7 sìtA for hver (šekel) som du sælger af olie,

16. til hvad 40 (šekel) sølv svarer? 40 løft til 7,

17. 440 ser du, $\quad 440$ (SìLA) olie.

Vi møder her endnu en opgave der for en overfladisk betragtning synes at have praktisk relevans, og som ved nøjere undersøgelse viser sig at være kunstig ud over alle grænser: en købmand har købt $M=2$ GUR 2 PI 5 BÁN (= 12`50 SìLA) olie (antagelig sesamolie). Vi får ikke at vide hvad han har givet, men derimod at han fra den mængde $(k)$ han har købt for hver šekel (ca. 8 gram) sølv har fjernet 4 SìLA og solgt resten $(s=k-4)$

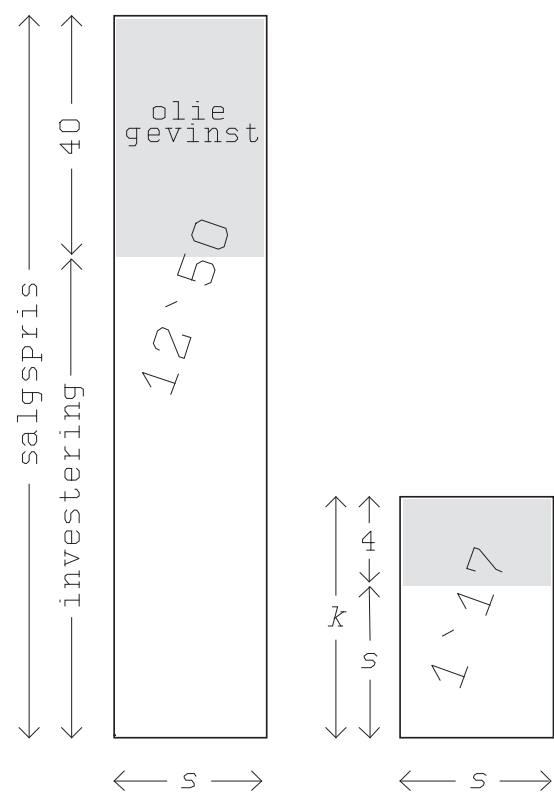

Figur 29. Geometrisk repræsentation af TMS XIII. videre for 1 šekel; $k$ og $s$ er altså reciprokke priser - vi kan for at have en betegnelse kalde dem købs- og salgsrater. Endvidere fortælles det at hans samlede fortjeneste har været $F=2 / 3$ mina $=40$ šekel. For os er det ikke svært at se at den samlede indkøbspris (investeringen) er $\mathrm{M} / \mathrm{k}$ og den samlede salgspris $M / s$, og fortjenesten altså $F=M / s-M / k$. Ved at multiplicere med $k \cdot s$ får vi herfra ligningen $M \cdot(k-s)=$ $F \cdot k s$, og da $s=k-4$ altså systemet 


$$
k-s=4, \quad k \cdot s=4 M / F .
$$

Det ligningssystem - af samme type som YBC 6967, igûm-igibûmopgaven (side 36) - løses da også fra linie 8 og fremefter. Men babylonierne har ganske sikkert ikke fundet frem til det som vi gjorde: dels fordi de ikke havde vore algebraiske symboler, dels fordi de så ville have fundet størrelsen $4 \mathrm{M} / \mathrm{F}$ og ikke, som det sker, $4 / F \cdot M$.

Nøglen til hvad de i stedet gjorde findes i opgavens slutning. Her beregnes først den samlede investering (1`10 šekel) og dernæst gevinsten i olie (4 40 sìtA). Der er ikke tale om en prøve, for de to størrelser var ikke blandt de givne. På den anden side blev der heller ikke spurgt efter dem. De må altså have spillet en rolle i selve løsningen.

Figur 29 viser hvordan de kan have gjort det. Vi kan repræsentere den samlede oliemængde ved et rektangel, hvis højde er den totale salgspris (antal šekel) og hvis bredde er salgsraten $s$ (SìLA pr. šekel). Salgsprisen kan vi splitte op i fortjeneste (40 šekel) og investering (indkøbspris), og oliemængden tilsvarende i oliegevinsten og den mængde der ved salget giver den oprindelige investering igen.

$\mathrm{Nu}$ må forholdet mellem disse to sidste størrelser være som det tilsvarende for den mængde der er købt for 1 šekel - altså som mellem 4 sìlA og det der sælges for 1 šekel (altså s). Hvis vi ændrer på skalaen i lodret retning med en faktor der reducerer 40 til 4 - altså en faktor ${ }^{4} / 40=6^{\prime}$ - så vil samtidig investeringen blive reduceret til s. Det giver os altså rektanglet til højre, hvor vi kender arealet $(k \cdot s=1 ` 17)$ samt forskellen mellem siderne $(k-s=4)$, præcis som vi har brug for; endvidere bliver regneopera- 
tionernes rækkefølge som i teksten, og både oliegevinst og investering spiller en rolle $i$ argumentet.

Selve løsningen af ligningssystemet foregår stort set som i YBC 6967 (og alle andre opgaver af samme type). Den eneste afvigelse fra normaliteten har vi i linie 10: I stedet for at bruge den halvpart af $k-s$ som vi »lod holde « i linie 8, brækkes $k-s$ endnu engang i to; derfor kan vi tilføje først (det der skal tilføjes er allerede til rådighed), og vente med at udrive.

I YBC 6967, igûm-igibûm-opgaven (side 36), blev de geometriske størrelser brugt som repræsentanter for størrelser af en anden art, nemlig for tal; også i den nærværende opgave er der tale om repræsentation, men af mere kompliceret art: her står ét liniestykke for en sølvmængde, et andet for den oliemængde der svarer til 1 šekel sølv.

\section{BM 13901 nr. 12}

27. Fladerne af mine to modstillinger har jeg lagt $\mathrm{i}$ bunke: $21^{\prime} 40^{\prime \prime}$.

28. Mine modstillinger har jeg ladet holde: $10^{\prime}$.

29. Halvparten af $21^{\prime} 40^{\prime \prime}$ brækker du: $10^{\prime} 50^{\prime \prime}$ og 10'50" lader du holde,

30. 1`57"21" $40^{\prime \prime \prime \prime}$ er det. 10` og 10' lader du holde, 1'40"

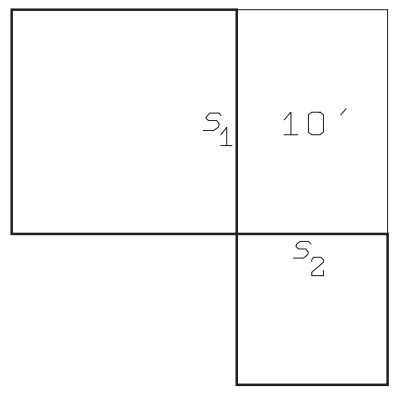

Figur 30. De to kvadrater og rektanglet fra BM 13901 nr. 12.

31. fra det indvendige af 1'57"21"40"' udriver du: 17"21"40"' gør 4'10" ligesidet. 
32. 4’10" til det ene 10`50" tilføjer du: 15’ gør 30’ ligesidet.

33. $30^{\prime}$ er den første modstilling.

34. $4^{\prime} 10^{\prime \prime}$ fra det indvendige af det andet 10`50" udriver du: 6'40" gør 20’ ligesidet.

35. 20` er den anden modstilling.

Hermed vender vi tilbage fra den algebraiske repræsentation af en fingeret virkelighed til en tilsyneladende mere »ren« algebra; samtidig møder vi et eksempel på repræsentation der ikke er mindre radikalt end den foregående opgaves.

Opgaven stammer fra den samling af »kvadratproblemer« vi allerede har trukket på flere gange. Den fore-

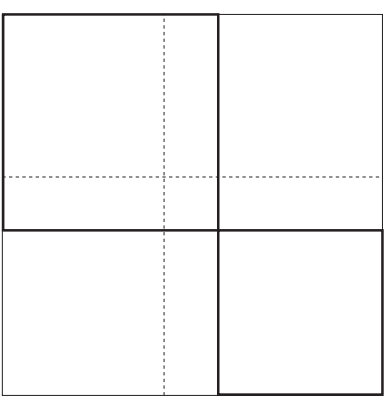

Figur 31. Diagrammet svarende til BM 13901 nr. 8. liggende opgave handler om to kvadrater, hvis arealsum er givet sammen med arealet af det rektangel der har sider $s_{1}$ og $s_{2}$; alt $\mathrm{i}$ alt

$$
\square\left(s_{1}\right)+\square\left(s_{2}\right)=21^{\prime} 40^{\prime \prime}, \quad \sqsubset \sqsupset\left(s_{1}, s_{2}\right)=10^{\prime},
$$

som vist i Figur 30. Opgaven kunne uden vanskelighed være blevet løst ved hjælp af diagrammet i Figur 31, der efter alt at dømme allerede har været benyttet som underlag for løsningen af samme tavles opgave nr. 8, som lyder:

$$
\square\left(s_{1}\right)+\square\left(s_{2}\right)=21^{\prime} 40^{\prime \prime}, s_{1}+s_{2}=50^{\prime} .
$$

I stedet gør teksten noget helt andet - endnu et eksempel på den babyloniske algebras fleksibilitet: den betragter de to arealer $\square\left(s_{1}\right)$ og $\square\left(s_{2}\right)$ som sider i et rektangel, hvis areal beregnes ved 
at lade 10' og 10' "holde" (se Figur 32). Det giver os ligningssystemet

$$
\begin{gathered}
\square\left(s_{1}\right)+\square\left(s_{2}\right)=21^{\prime} 40^{\prime \prime}, \\
\sqsubset \sqsupset\left(\square\left(s_{1}\right), \square\left(s_{2}\right)\right)=10^{\prime 2}=1^{\prime} 40^{\prime \prime} .
\end{gathered}
$$

Uanset operationernes geometriske karakter var babylonierne altså

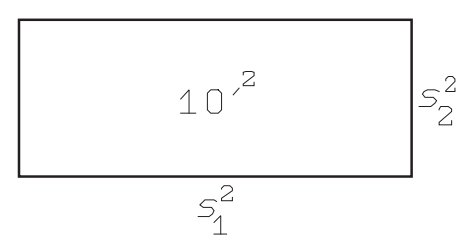

Figur 32. BM 13901 nr. 12 transformeret til rektangelproblem.

ganske klar over at arealet af et rektangel med sider lig kvadratarealerne $\square\left(s_{1}\right)$ og $\square\left(s_{2}\right)$ var det samme som et kvadratet hvis side var arealet af rektanglet $\sqsubset \sqsupset\left(s_{1}, s_{2}\right)$, svarende til vor aritmetiske regel $p^{2} \cdot q^{2}=$ $(p q)^{2}$.

$\mathrm{Nu}$ står vi altså over for et rektangel hvor vi kender arealet og summen af de to sider, præcis som i TMS IX nr. 3 og AO 8862 nr. 2. Det videre forløb er

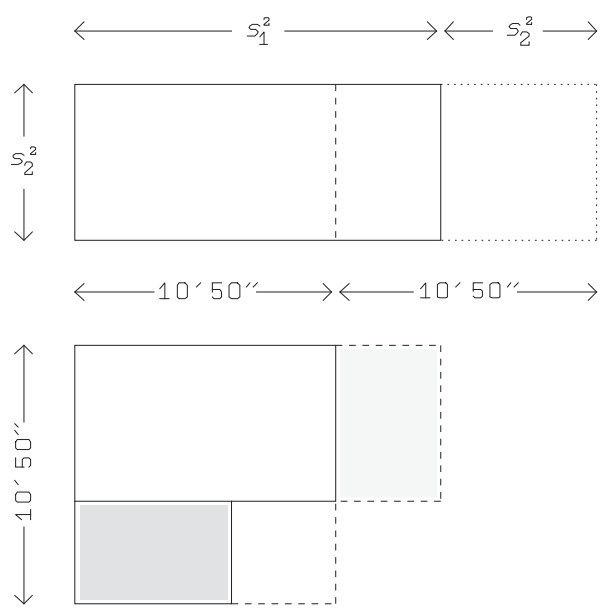

Figur 33. Proceduren til løsning af rektangelproblemet. også ganske som vi er vant til fra disse tekster, blot med den tilføjelse at proceduren i første omgang kun giver os $\square\left(s_{1}\right)$ og $\square\left(s_{2}\right)$ som rektanglets sider; $s_{1}$ og $s_{2}$ selv må findes som de »ligesidede« af disse. Udregningerne kan følges på Figur 33.

Det bemærkelsesværdige ved opgaven er altså at den lader 
liniestykker repræsentere arealer, og lader et areal repræsentere kvadratet på et areal. Repræsentation findes også i andre tekster, som vi har set; men alt tyder på at den aktuelle tekst er den ældste vi kender hvor egentlig repræsentation forekommer. Den er dermed, som vi skal argumentere for på side 107, det første tegn på at den babyloniske algebra virkelig kan betragtes som en algebra.

BM 13901 nr. 23

\section{Bs II}

11. Angående en flade. De fire fronter og fladen har jeg lagt $\mathrm{i}$ bunke, $41^{\prime} 40^{\prime \prime}$.

12. 4 , de fire fronter, indskriver du. IGI af 4 er $15^{\prime}$.

13. $15^{\prime}$ til $41^{\prime} 40^{\prime \prime}$ løfter du, 10`25" indskriver du.

14. 1, fremspringet, tilføjer du: $1^{\circ} 10^{\prime} 25^{\prime \prime}$ gør $1^{\circ} 5^{\prime}$ ligesidet.

15. 1 , fremspringet som du har tilføjet, udriver du: $5^{\prime}$ til to

16. gentager du: 10` NINDAN står imod sig selv.

Hvor den foregående opgave var et eksempel på den babyloniske matematisk mest »moderne « aspekt, er denne (skønt stammende fra samme tavle) en repræsentant for dens arkaiske side.

Antagelig er den villet arkaisk. Mange træk i formuleringen ser ud til bevidst at efterligne de akkadiske landmåleres sprogbrug: bl.a. »fronten «, ikke »modstillingen «, samt det indledende "angående en flade", som efter alt at dømme er en forkortet variant af den gamle gådeinddeling, »Hvis angående en flade nogen har sagt dig « (jfr. side 35 og 141). Opgaven selv er endvidere - blandt andet ved den måde hvorpå den udvælger det 
slående, netop de fire fronter ${ }^{[20]}$ og ikke blot fronten taget fire gange - en typisk gåde af en type som trives blandt matematiske praktikere (se side 115). Også metoden er karakteristisk for gåderne: brugen af et slående trick som ikke lader sig generalisere.

Problemet kan altså gengives

$$
4 s+\square(s)=41^{\prime} 40^{\prime \prime} .
$$

Hvad der foregår kan ses i Figur 34: 4s repræsenteres ved 4 rektangler $\sqsubset \sqsupset(1, s)$, og hele summen altså af den viste korsformede konfiguration, hvor »fremspringet « stikker ud $i$ alle fire retninger. I linie 12-13 tages $1 / 4$ af korset,

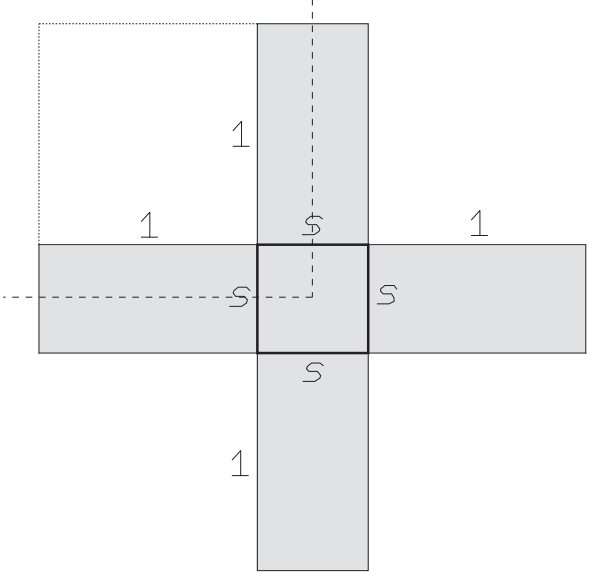

Figur 34. Fremgangsmåden i BM 13901 nr. 23. markeret med den stiplede linie, og der tilføjes et kvadratisk komplement $\square$ (1) til det fremkomne gnomon. Der er intet behov for at konstruere komplementet ved at lade 1 og 1 »holde«-de er jo allerede på plads. Derimod sker der det slående at den tilføjede kvadratiske konfiguration identificeres med den side der bestemmer den (»1, fremspringet «, linie 14;); det er altså virkelig den geometriske konfiguration der tilføjes, og ikke et tal - jfr. diskussionen af

${ }^{20}$ Som påpeget på side 25 har babylonisk ikke nogen systematisk skelnen mellem bestemt og ubestemt form; desto stærkere virker det når der bruges et udtryk der fastlægger netop de eller alle fire. 
begrebet »modstilling « side 23. Det kompletterede gnomon bliver et kvadrat med areal $1^{\circ} 10^{\prime} 25^{\prime \prime}$ og altså med »ligeside « $1^{\circ} 5^{\prime}$. Udrives nu det tilføjede "fremspring " (denne gang som liniestykke) får vi 5' tilbage, der fordobles konkret (spejles) og dermed giver siden 10'.

Metoden afviger i en sådan grad fra alt hvad vi ellers kender til at en af de første udgivere tog den for en afskriverfejltagelse der ved et tilfælde gav matematisk mening. Som vi skal se (side 119) er der tale om noget helt andet.

\section{TMS VIII nr. 1}

1. Fladen $10^{\prime}$. 4.-delen af bredden til bredden har jeg tilføjet, til 3 er jeg gået. Det

2. overstiger længden med $5^{\prime}$. Du, 4 , fra fjerdedelen, så meget som bredden sæt. Fjerdedelen af 4 tag, 1 ser du.

3. 1 til 3 gå, 3 ser du. 4 fjerdedele af bredden til 3 tilføj, 7 ser du.

4. 7 så meget som længden sæt. 7, fra længden, til 4 løft,

5. 28 ser du, 28 flader. 28 til 10', fladen, løft, $4^{\circ} 40^{\prime}$ ser du.

6. $5^{\prime}$, udrivningen fra længden, til 4 , fra bredden, løft, 20' ser du. $1 / 2$ bræk, 10' ser du. Lad holde,

7. $1^{\prime} 40^{\prime \prime}$ ser du. $1^{\prime} 40^{\prime \prime}$ til $4^{\circ} 40^{\prime}$ tilføj, $4^{\circ} 41^{\prime} 40^{\prime \prime}$ ser du. Hvad gøres ligesidet? $2^{\circ} 10^{\prime}$ ser $\mathrm{du}$.

8. $10^{\prime}$ den ligestore (?) til $2^{\circ} 10^{\prime}$ tilføj, $2^{\circ} 20^{\prime}$ ser du. Hvad til 28 , fladerne, skal jeg sætte som $2^{\circ} 20^{\prime}$ giver mig?

9. $\quad 5^{\prime}$ sæt. $5^{\prime}$ til 7 løft, $35^{\prime}$ ser du. 5', udrivningen fra længden, fra $35^{\prime}$ udriv,

10. 30` ser du, 30' er længden. 5', længden, til 4 fra bredden løft, 20` ser du, 20` er længden (skrivefejl for bredden). 
BM 13901 nr. 12 viste hvorledes et kvadratproblem blev reduceret til og løst som et rektangelproblem. Her bliver til gengæld et rektangelproblem reduceret til og løst som et kvadratproblem.

I oversættelse til sym-

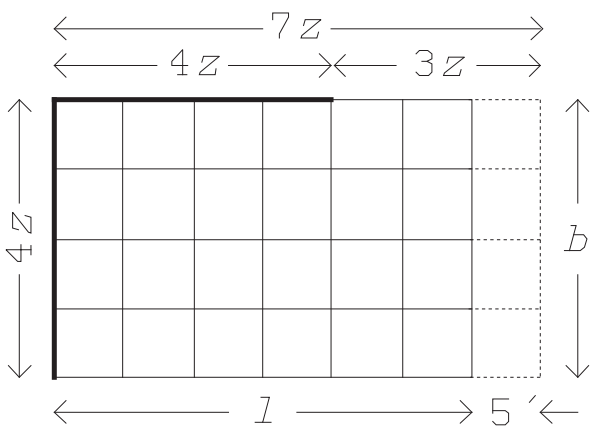

Figur 35. Metoden fra TMS VIII nr. 1. boler er problemet følgende:

$$
7 / 4 b-l=5^{\prime}, \quad \sqsubset \exists(l, b)=10^{\prime} .
$$

Det kunne være løst efter samme principper som TMS IX nr. 3 (side 63), i følgende trin:

$$
\begin{gathered}
7 b-4 l=4 \cdot 5^{\prime}, \quad \sqsubset \neg(l, b)=10^{\prime} \\
7 b-4 l=20^{\prime}, \quad \sqsubset \exists(7 b, 4 l)=(7 \cdot 4) \cdot 10^{\prime}=28 \cdot 10^{\prime}=4^{\circ} 40^{\prime} \\
7 b=\sqrt{4^{\circ} 40^{\prime}+\left(\frac{20^{\prime}}{2}\right)^{2}+\frac{20^{\prime}}{2}}=2^{\circ} 20, \\
4 l=\sqrt{4^{\circ} 40^{\prime}+\left(\frac{20^{\prime}}{2}\right)^{2}}-\frac{20^{\prime}}{2}=2 \\
b=20^{\prime}, \quad l=30^{\prime} .
\end{gathered}
$$

Men som vi efterhånden har været ude for adskillige gange viser den babyloniske regner os at han har flere metoder til rådighed som han kan vælge mellem efter hvad der forekommer bekvemt. Denne gang benyttes et kvadrat hvis side $(z)$ er $1 / 4$ af bredden - 
se Figur 35. Linie 4 finder at rektanglet med sider $7 z$ og $4 z-$ altså det oprindelige rektangel forlænget med 5' - består af $7 \cdot 4=28$ små kvadrater (at multiplikationen er en løftning viser at der ikke er tale om konstruktion af et nyt rektangel men om opdeling af det eksisterende, jfr. den alternative tolkning af BM 13901 nr. 10 i note 11). De overstiger tilsammen arealet $10^{\prime}$ med en vist

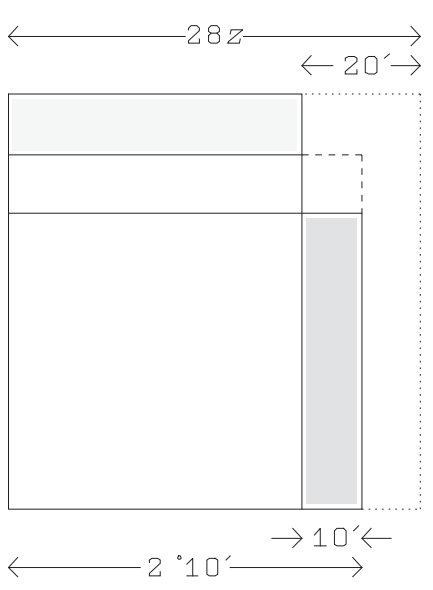

Figur 36. Løsning af den normaliserede ligning i TMS VIII nr. 1. antal sider $(n \cdot z)$, hvis beregning udskydes lidt. Først transformeres nemlig som sædvanlig det ikke-normaliserede problem

$$
28 \square(z)-n \cdot z=10^{\prime}
$$

til

$$
\square(28 z)-n \cdot(28 z)=28 \cdot 10^{\prime}=4^{\circ} 40^{\prime} .
$$

Linie 6 finder $n=4 \cdot 5^{\prime}=20^{\prime}$, og så går alt rutinemæssigt i overensstemmelse med Figur 36; $28 z$ bliver $2^{\circ} 20^{\prime}, z$ dermed $5^{\prime}$. Altså er længden $l=7 \cdot 5^{\prime}-5^{\prime}=30^{\prime}$ og bredden $b=4 \cdot 5^{\prime}=20$. 


\section{YBC 6504 nr. 4}

\section{Bs}

11. Så meget som længden overstiger bredden, stødt sammen (med sig selv), fra det indvendige af fladen har jeg udrevet:

12. $8^{\prime} 20^{\prime \prime} .20^{\prime}$ er bredden, dets længde hvad?

13. 20' stødt sammen (med sig selv): 6'40" sætter du.

14. 6'40" til 8'20" tilføjer du: $15^{\prime}$ sætter du.

15. $15^{\prime}$ gør 30’ ligesidet. 30’ som længde sætter du.

Hidtil har alt hvad vi har set på været matematisk korrekt, bortset fra nogle skrive- og afskrivningsfejl. Men selvfølgelig kunne også babylonierne, som alle andre der beskæftiger sig med matematik, komme til at begå egentlige argumentationsfejl.

Det er denne sidste andengradstekst et eksempel på. Oversat til symboler fortæller den om et rektangel at

$$
\sqsubset \sqsupset(l, b)-\square(l-b)=8^{\prime} 20^{\prime \prime}, \quad b=20^{\prime},
$$

hvorefter den beregner $l$ som ligesiden af $\sqsubset \sqsupset(l, b)-\square(l-b)+b^{2}$, d.v.s., efter omregning og i vores moderne udtryksmåde, som $\sqrt{(3 b-l) \cdot l}$.

Fejlen synes svær at fatte, indtil man betragter geometrien i argumentet - se Figur 37. Øverst i figuren vises proceduren i forvrænget målestok; vi ser at tilføjelsen af $\square(b)$ forudsætter at vi skærer op langs den stiplede linie og åbner til et pseudognomon. Det er klart på denne figur at den kompletterede figur ikke er $\square(l)$ men netop - hvis vi tæller efter $-\sqsubset \sqsupset(3 b-l, l)$. Ser vi derimod på den nederste version er det ikke længere indlysende. Her er alt tegnet i korrekte mål, $l=30^{\prime}$ og $b=20^{\prime}$, og derfor bliver $l-b=b-(l-b)$. Det indebærer at den kompletterede figur netop 


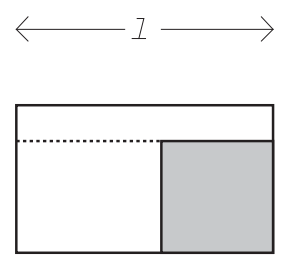

$\longleftrightarrow b \rightarrow I-b<$

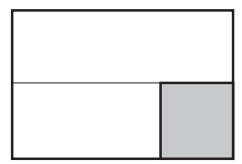

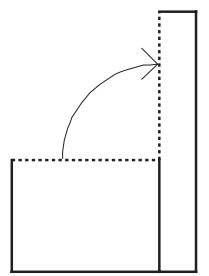
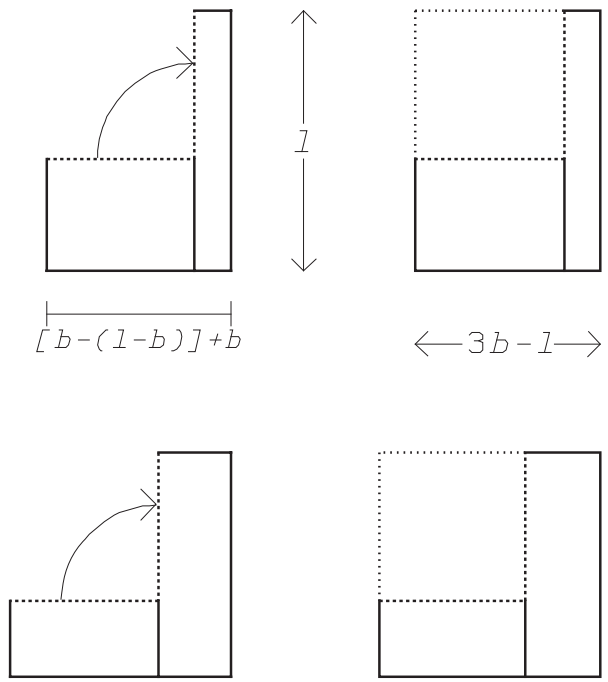

Figur 37. Klippe-klistre-operationerne i YBC 6504 nr. 4; for oven i forvrænget målestok, for neden i korrekte, vildledende mål.

er kvadratet $\square(l)-$ men altså kun fordi $l=3 / 2 b$.

Fejltagelsen illustrerer et kendetegn for den naiv-geometriske metode: den kræver, som geometriske beviser i det hele taget, stor påpasselighed hvis man vil undgå at blive vildledt af hvad man umiddelbart kan "se " på figuren. Det vidner om de babyloniske regneres dygtighed at de så sjældent lod sig vildlede, og at de med så få undtagelser var i stand til kun at bruge de oplysninger der ifølge opgaveformuleringerne var givet, og til at se bort fra hvad de i øvrigt vidste. 


\section{KVASI-ALGEBRAISKE TEKNIKKER I GEOMETRI M.V.}

Vi har stadig ikke taget stilling til hvad vi mener med ordet »algebra", og ethvert skel mellem babylonisk »algebra « og »kvasialgebraiske teknikker « er derfor i bedste fald foreløbigt, en hypotese der tillader os at oparbejde materiale til at tage en mere indgående diskussion af spørgsmålet.

Under alle omstændigheder lader samtlige de opgaver der optræder i kapitel II til IV sig let (omend med tab af nuancer) oversætte til moderne matematiske symboler og ligninger; det samme gælder i grove træk de metoder der bliver brugt til at løse opgaverne.

Det gælder ikke i samme omfang de to opgaver der analyseres i dette kapitel. På den anden side er der nær forbindelse mellem de teknikker der bruges her og dem vi allerede har set anvendt. I hvert fald i den forstand kan det være rimeligt at betragte dem som »næsten-algebraiske«.

\section{VAT 8512}

Fs

1. En trekant. 30 er bredden. Indvendig to jordlodder.

2. Den øvre flade overstiger den nedre med 7 ;

3. den nedre lodlinie overstiger den øvre lodlinie med 20.

4. Lodlinierne og grænsen hvad?

5. Og fladerne af de to jordlodder hvad?

6. Du, 30, bredden, sæt; $7^{`}$, som den øvre flade overstiger 
den nedre flade med, sæt;

7. og 20, som den nedre lodlinie overstiger den øvre lodlinie med, sæt.

8. IGI af 20, som den nedre lodlinie overstiger den øvre med,

9. fraspalt: $3^{\prime}$ til $7^{\prime}$, som den øvre flade overstiger den nedre flade med,

10. løft, 21 skal dit hoved beholde!

11. 21 til 30, bredden, tilføj: 51

12. sammen med 51 lad holde: $43 ` 21$.

13. 21, som dit hoved beholder, sammen med 21

14. lad holde: $7 ` 21$ til $43 ` 21$ tilføj: $50 ` 42$.

15. $50 ` 42$ til to bræk: 2521 .

16. Den ligesidede af $25 ` 21$ hvad? 39.

17. Fra 39, 21, det som holdt, udriv, 18.

18. 18 som du har efterladt er grænsen.

19. Nuvel, hvis 18 er grænsen,

20. lodlinierne og fladerne for de to jordlodder hvad?

21. Du, 21 som sammen med sig selv du lod holde, fra 51

22. udriv: 30 efterlader du. 30, som du har efterladt,

23. til to bræk, 15 til 30, som du har efterladt, løft,

24. $\quad 7 ` 30$ skal dit hoved beholde!

\section{Rand}

1. 18 , grænsen, sammen med 18 lad holde:

2. $5 ` 24$ fra $7 ` 30$, som dit hoved beholder,

3. udriv: $2 \lessdot 6$ efterlader du.

Bs

1. Hvad til $2 ` 6$ skal jeg sætte

2. som giver mig $7^{`}$, som den øvre flade overstiger den nedre flade med?

3. $\quad 3^{\circ} 20^{\prime}$ sæt. $3^{\circ} 20^{\prime}$ til $2^{`} 6$ løft, $7^{\prime}$ giver det dig.

4. $\quad 30$, bredden, overstiger 18, grænsen, med hvad? Med 12 overstiger den. 
5. $\quad 12$ til $3^{\circ} 20^{\prime}$, som du har sat, løft, 40 .

6. 40 er den øvre lodlinie.

7. Nuvel, hvis 40 er den øvre lodlinie,

8. den øvre flade er hvad? Du, 30, bredden, (og)

9. 18 , grænsen, læg i bunke: 48 til to bræk: 24 .

10. 24 til 40, den øvre lodlinie, løft, 16 .

11. 16`er den øvre flade. Nuvel, hvis $16^{`}$ er den øvre flade,

12. den nedre lodlinie og den nedre flade hvad?

13. Du, 40, den øvre lodlinie, til 20 som den nedre lodlinie overstiger den øvre lodlinie med,

14. tilføj, 1 er den nedre lodlinie.

15. 18, grænsen, til to bræk: 9

16. til 1', den nedre lodlinie, løft, 9'.

17. 9 er den nedre flade.

Ikke så få babyloniske matematikopgaver handler om opdeling af marker. Det matematiske indhold varierer - undertiden ind går markens form overhovedet ikke men kun dens areal, undertiden er der som her tale om opdeling af bestemte geometriske figurer.

Allerede inden 2200 f.v.t. var de mesopotamiske landmålere i stand til at opdele et trapez i to lige store dele ved hjælp af en paralleltransversal. Hvordan de bar sig ad skal vi vende tilbage til om et øjeblik; men det er værd at lægge mærke til at en tilsvarende opdeling af en trekant ikke er mulig uden brug af irrationelle forhold, og altså kun kan beskrives med tilnærmelse i tal.

Den nærværende opgave er en variant af trekantopdelingen, som i modsætning til ligedelingen kan løses eksakt. Den handler, som forklaret i linie 1-3 og vist i Figur 38, om en trekantet mark, der er opdelt i to lodder. For nemheds skyld kan vi regne trekan- 
ten for retvinklet: det gjorde forfatteren $\mathrm{u}$ tvivlsomt også, og det er antagelig hvad der ligger i ordet »lodlinien« eller »den nedstigende«; men

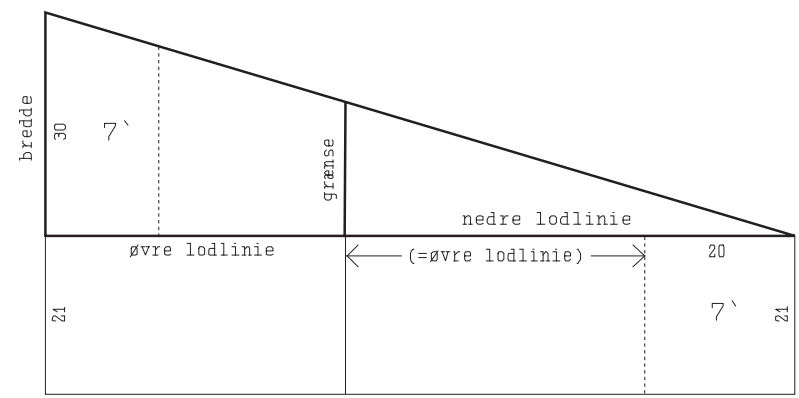

Figur 38. Den opdelte trekantede mark fra BM 8512, med det tilføjede hjælperektangel.

hvis vi tolker dette ord som en højde og ikke som en side gælder alle beregninger også for skævvinklede trekanter.

De to lodder er af gode grunde ikke lige store; men vi kender forskellen mellem deres arealer, og forskellen mellem »lodlinierne«. Løsningen kan umiddelbart forekomme svært gennemskuelig, idet den gør brug af et uventet, elegant trick.

Fs 8-10 løfter den reciprokke af forskellen mellem lodlinierne til arealforskellen; tager man valget af multiplikativ operation i betragtning vil det sige at teksten beregner bredden af et rektangel hvis længde er lodliniernes differens og hvis areal er arealforskellen. Denne bredde (som bliver 21) tilføjes til trekantens bredde.

Ud af det kommer altså en trekant med et vedføjet rektangel, alt $i$ alt et trapez, som vist på Figur 38. Forlænger vi paralleltransversalen (»grænsen« mellem de to lodder), opdager vi at den deler trapezet $i$ to lige store stykker; og det var som sagt en opgave som regionens landmålere havde kunnet løse i mindst 500 år, da den foreliggende opgave blev konstrueret.

I Fs 11-16 ser vi hvordan de bar sig ad: Den tvedelende paral- 
leltransversal findes som siden af gennemsnittet af kvadraterne på de to parallelle sider; af valget af operationer (»holde«; »brække«) ser vi at der udtrykkelig er tænkt på geometriske kvadrater og gennemsnit. Figur 39 viser os både hvad der foregår og hvorfor: Gennemsnittet ligger lige langt fra de to yderligheder, og derfor

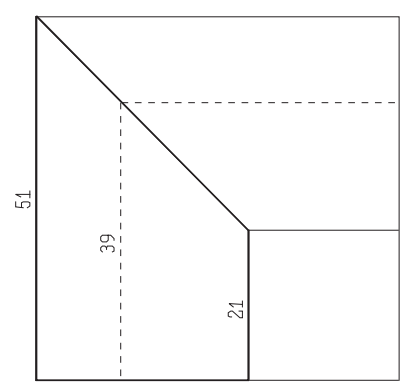

Figur 39.Trapeztvedelingen i BM 8512. må også det halve gnomon mellem 21 og 39 være lige så stor som det halve gnomon mellem 39 og 51. Det gælder naturligvis umiddelbart for et trapez der skæres ud langs diagonalen i et kvadrat; men hvis vi forestiller os kvadratet strakt (og eventuelt skævtrukket), kan vi forestille os at den samme regel må gælde for trapezer i almindelighed. Men strækning er jo netop en operation som vi har set babylonierne bruge gang på gang: det er det »skalaskift i én retning « som optrådte hver gang et andengradsproblem skulle normaliseres, og som også blev anvendt i TMS XIII, oliehandelsopgaven (se side 80); som vi skal se anvendes princippet også senere i den aktuelle opgave.

Oprindelig er reglen antagelig blevet opdaget ved betragtning af to koncentrisk anbragte kvadrater (se Figur 40) - denne konfiguration var et meget populært undersøgelsesobjekt i babylonisk geometri, og forbliver det i bygmestergeometri indtil renæssancen; men princippet er naturligvis det samme.

I Fs 17 er altså trapezets tvedelende transversal blevet fundet; den er 39, og "grænsen« mellem de to jordlodder dermed 38-21 = 18. 
Nu sker der noget påfaldende. I Fs 21-22 findes trekantens bredde, selv om den var blandt de givne størrelser. Det kan antagelig kun betyde at vi faktisk har bevæget os væk fra Figur 38 og hen i retning af noget der ligner Figur 39. Når vi fjerner de 21 bliver den oprindelige trekant trængt sammen så den bliver ligebenet, som vi kan se i Figur 41.

For at finde den øvre lodlinie gør teksten brug af den falske ansats at den sammentrængte, ligebenede trekant er den vi søger, og længden (lodliniernes sum) altså 30 ligesom bredden; der er altså tale om et skalaskift i længdens retning, et trick vi allerede kender fra normaliseringen af de ikke-normaliserede

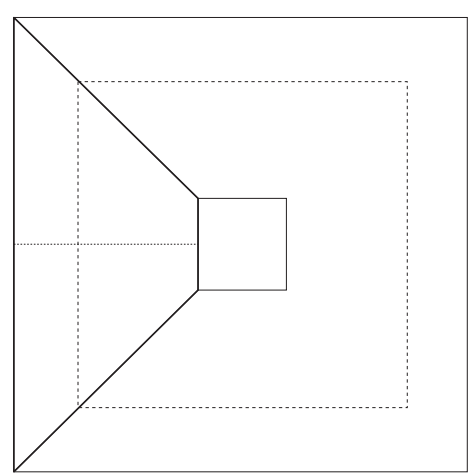

Figur 40.Trapeztvedeling ud fra koncentriske kvadrater.

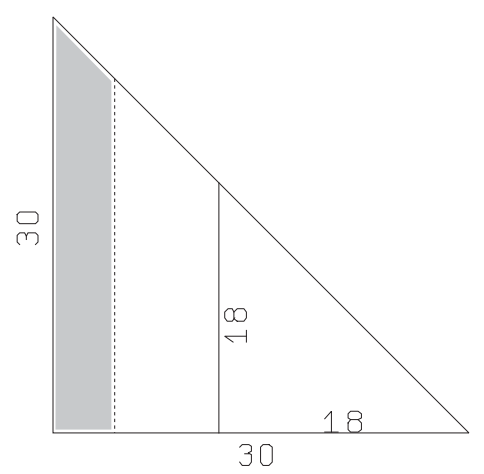

Figur 41. andengradsligninger. Fs 23-24 finder at denne trekants areal er 7`30. De to ikke-skraverede områder er jo lige store, så deres samlede areal må være 18 $18=$ $5 ` 24$. Det skraverede område - som svarer til forskellen mellem de to jordlodders arealer - bliver dermed 7`30-5`24 = 2`6 (Rand $1-3)$.

I virkeligheden er forskellen $7^{`}$ og ikke $2^{`} 6$. Bs 1-3 finder 
frem til at vi for at få den sande forskel 7 `skal multiplicere det sammentrængte areal $2^{`} 6$ med $3^{\circ} 20^{\prime}$. Da bredden ligger fast den er 30 - må længden 18 altså multipliceres med denne faktor. Den øvre lodlinie bliver altså $3^{\circ} 20^{\prime} \cdot(30-18)=40$ (Bs 6). Derefter går alt på simpel vis - ikke den allersimpleste, men utvivlsomt den pædagogisk mest givtige.

Der er selvfølgelig stor forskel på denne opgaveløsning og dem vi ellers har set på. Men der er også fællestræk, som bliver synlige når metoden ses i fugleperspektiv.

Det fællestræk der falder mest i øjnene blev allerede nævnt: skalaskiftet i én retning. Men også én af de åbenlyse forskelle fraværet af den kvadratiske komplettering, den »akkadiske metode« - peger på et slægtskab: Tilføjelsen af en hjælpefigur som sidenhen elimineres igen.

Mere fundamentalt er dog den fælles »analytiske« karakter af løsningsmetoderne. Siden grækerne har man talt om at løsningen på et matematisk problem er analytisk hvis man går ud fra at det allerede er løst og så undersøger - analyserer - hvordan løsningen ser ud, så man på den måde kan se hvordan den kan konstrueres. $^{[21]}$

\footnotetext{
${ }^{21}$ Modsætningen til den »analytiske« metode er den syntetiske, hvor man direkte konstruerer sin løsning og derefter viser at det fremkomne løser det stillede problem; sådan er Euklids Elementer formuleret, og det har været et tilbagevendende klagepunkt siden oldtiden at det gør værket vanskeligt: man forstår umiddelbart ikke hvorfor de enkelte trin foretages, uanset at man til sidst indser at den snedige forfatter åbenbart havde ret. Der har også lige siden bestået en mistanke om at Euklid (eller hans forgængere) først har fundet deres løsninger analytisk og
} 
Løsning ved hjælp af moderne ligningsalgebra er altid analytisk. Lad os vende tilbage til TMS XIII, opgaven om køb og salg af olie (side 78). Vi går ud fra at antallet af sìtA der købes for 1 šekel sølv er et kendt tal, og kalder det $k$; det samme forudsætter vi om salgsraten $s$. Altså er den samlede investering $M / k$, den samlede salgspris $M / s$, og fortjenesten altså $F=M / s-M / k$ Så multiplicerer vi med $s \cdot k$, o.s.v. Ofte forklarer vi det med den vending at vi behandler $s$ og $k$ som om de var normale, kendte tal, men essensen forbliver den samme: vi går ud fra at vi har en løsning og skriver dens karakteristika op, hvorefter vi arbejder os frem til dens konsekvenser $-i$ sidste ende $k=11, s=7$.

Også de babyloniske klippe-klistre-løsninger er analytiske: Vi går ud fra eksistensen af løsningen, et rektangel med areal $1^{\circ} 17$ og en længde der overstiger bredden med 4. Denne løsnings kendetegn analyserer vi så, ser hvor meget den skal suppleres med for at give et kvadrat af kendt areal, o.s.v.

Men også den nærværende opgaves løsning er analytisk: Vi går ud fra at trekanten er suppleret med et rektangel så tvedelingen bliver til en ligedeling, og beregner så hvad bredden af suppleringsrektanglet skal være; o.s.v. Det skel der fra vores synsvinkel er mellem »algebra " (opgaver der uden større forvrængning kan oversættes til moderne ligningsalgebra) og »kvasialgebra « (opgaver hvor en sådan oversættelse fører til klare forvrængninger af løsningsmetoden) er, hvis ikke fraværende, så i hvert fald mindre afgørende i de babyloniske teksters eget perspektiv.

først derefter konstrueret den syntetiske løsning. 


\section{BM 85200+VAT 6599 nr. 6}

\section{Fs I}

9. $\quad$ En kælder. Så meget som længden: dybden. 1 den jord jeg har udrevet. Mit gulv og jorden har jeg lagt i bunke, $1^{\circ} 10^{\prime}$. Længde og bredde, 50’. Længde, bredde, hvad?

10. Du, 50` til 1, omsætningen, løft, 50` ser du. 50` til 12 løft, 10 ser du.

11. 50' lad stå mod sig selv, 41'40" ser du, til 10 løft, $6^{\circ} 56^{\prime} 40^{\prime \prime}$ ser du. Dets IGI fraspalt, 8’38"24"' ser du,

12. til $1^{\circ} 10^{\prime}$ løft, $10^{\prime} 4^{\prime \prime} 48^{\prime \prime \prime}$ ser du; $36^{\prime}, 2^{\prime} 4^{\prime}, 42^{\prime}$ er ligesiderne.

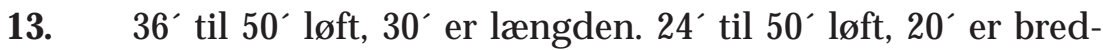
den. $36^{\prime}$ til 10 løft, 6 er dybden.

14. Fremgangsmåden.

Dette er et problem af 3. grad fra en brækket lertavle hvis ene del befinder sig i London og den anden i Berlin (heraf dens usædvanlige navn). Det handler som vi ser om en »kælder« af form som et rektangulært prisme, med længde $l$ [NINDAN], bredde $b$ [NINDAN] og dybde $d$ [KUŠ]. Vi făr at vide at længden er lig dybden, men på grund af de forskellige enheder for vandret og lodret mål betyder det at $d=12 \cdot l$.

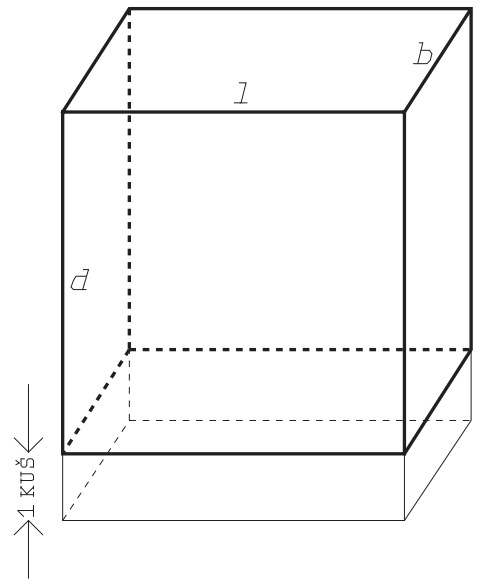

Figur 42. Kælderen fra BM 85200+VAT 6599 nr. 6, forlænget nedad med 1 KUŠ.

Endvidere får vi at vide at summen af længde og bredde 
er $[l+b=] 50^{\prime}$, og at summen af det udgravede rumfang og grundfladen er $[l \cdot b \cdot d+l \cdot b=] 1^{\circ} 10^{\prime}$. Den sidste ligning kan omskrives til $l \cdot b \cdot(d+1)=1^{\circ} 10^{\prime}$, hvad der betyder at rumfanget af kælderen hvis den forlænges nedefter med 1 ekstra KUŠ bliver $1^{\circ} 10^{\prime}\left[\mathrm{NINDAN}^{2} \cdot \mathrm{KUŠ}\right]$ - jfr. Figur 42. ${ }^{[2]}$

Ideen i opgaveløsningen er en raffineret variant af den simple falske ansats (i sin egentlige form kan metoden ikke bruges, da problemet jo er inhomogent - jævnfør note 12). »Ansatsen « går ud på at konstruere en sammenligningsterning med kantlængde $l+b$. I vandret afstandsmål er kantlængden selvfølgelig 1 150` = 50` [NINDAN], »omsætningen « fra NINDAN til NINDAN kræver multiplikation med 1. I lodret afstandsmål er den $12 \cdot 50^{\prime}=10$ KUŠ, »omsætningen « fra NINDAN til KUŠ indebærer en multiplikation med 12 (begge omsætninger finder sted i linie 10).

I linie 11-12 udregnes rumfanget af sammenligningsterningen. Dette rumfang, som bliver 6 $6^{\circ} 6^{\prime} 40^{\prime \prime}$, indeholdes $10^{\prime} 4^{\prime \prime} 48^{\prime \prime}$ gange i den forlængede kælder.

Vi måler nu så at sige den forlængede kælder med sammenligningsterningens tilsvarende dimensioner. Hvis $p$ står for det antal gange 50` kan måles op i længden $l, q$ for det antal gange $50^{\prime}$ kan måles op i bredden $b$, og $r$ endelig for det antal gange 10 KUŠ (= 50' NINDAN) kan måles op i den forlængede dybde $d+1$ KUŠ, gælder

${ }^{22}$ Opgaveformuleringen refererer også til »1 den jord jeg har udrevet «, men oplysningen bruges ikke; vi har her et eksempel på en størrelse som er kendt men ikke givet, og hvis talværdi har tilladt læreren i sin forklaring at skelne rumfanget af den virkelige kælder (»1, jorden«) fra rumfanget af den med 1 KUŠ forlængede kælder (» $1^{\circ} 10$, jorden $\left.)\right)$. 


$$
\begin{gathered}
p \cdot 50^{\prime}+q \cdot 50^{\prime}=l+b=50^{\prime}, \text { og dermed } p+q=1, \\
r \cdot 10=d+1=12 l+1=12 \cdot p \cdot 50^{\prime}+1=10 p+1, \\
\quad \text { og dermed } r=p+1 / 10=p+6^{\prime}, \\
\quad \text { og endelig } p \cdot q \cdot r=10^{\prime} 4^{\prime \prime} 48^{\prime \prime \prime} .
\end{gathered}
$$

Det vi skal gøre (og som teksten gør sidst i linie 12) er at opløse 10`4"48" i tre faktorer $p, q$ og $r$ som opfylder disse

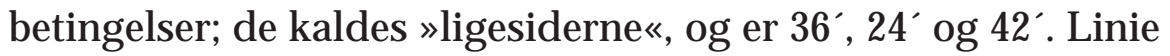
13 finder endelig $l, b$ og $d$ selv.

Det virker umiddelbart som om faktoriseringen bliver trukket op af den høje hat, og det er nok også tilfældet; da opgavekonstruktøren kender løsningen i forvejen, kan faktorerne nemt beregnes. Der er dog intet $\mathrm{i}$ vejen for at de kan findes ved systematisk prøven sig frem startende fra de simpleste tilfælde $10^{`} 4$ 4 $48=2^{6} \cdot 3^{4} \cdot 7$ skal blot opløses i faktorer $P, Q$ og $R$ hvor $P+Q=60, R=P+6 .{ }^{[23]} \mathrm{Ud}$ fra vort almindelige kendskab til den babyloniske matematikundervisnings kvalitet kan vi endda godt regne med at teksten kun tillader sig at trække løsningen op af hatten fordi løsningen om nødvendigt kan findes uden tryllekunster. Starter vi med gættet $P=1$, bliver $($ da $P+Q=60) Q=$ 59, hvad der straks kan forkastes da 59 ikke kan indgå i opløsningen; det samme sker når vi prøver $P=2$ og $P=3 ; P=$ 4 giver $R=10$, hvad der heller ikke er muligt; $P=5$ er selv ikke mulig; $P=6$ giver $Q=54$ og $R=12$, hvad der kan forkastes enten fordi ingen faktor 7 optræder, eller fordi produktet faktisk er forkert; den næste tilladte $P$-værdi der ikke fører til forbudte

${ }^{23}$ For at få hele tal er her indført $P=60 p=1 ` p, Q=1 ` q, R=1 ` r$. Så bliver $P Q R=1 “ " p q r=10 “ 448$. 
$Q$ - eller $R$-værdier er 12, der forkastes på samme måde; så kommer $P=18$, der dog må forkastes fordi produktet kun er omkring det halve af hvad det skulle være; ved $P=24$ og $P=$ 30 går det som ved $P=6$; så kommer endelig gættet $P=36$, som viser sig at passe. Hvis vi havde talt primfaktorer var det gået endnu hurtigere, men det trick er der ingen grund til at tilskrive babylonierne.

Men den metode fører selvfølgelig kun til målet fordi der faktisk findes en pæn løsning; derigennem adskiller situationen her sig grundlæggende fra løsningen af andengradsproblemer, hvor en god tilnærmelse til kvadratroden ville føre til en næsten rigtig løsning. Uanset om opløsningen er kaninen op af hatten eller forventes at blive fundet af eleven ved forsøg må vi sige at babylonierne altså ikke var i stand til at løse en tredjegradsligning i samme forstand som de løste andengradsproblemerne (det blev faktisk først det 16. århundredes italienske algebraikere i stand til).

Den nærværende opgave taler om tre ligesider; der er selvfølgelig tale om en generalisering af det begreb der optrådte ved løsningen af andengradsligningen, for faktorerne er jo netop ikke lige store. En sådan generalisering er der intet underligt i: vores egen ide om en lignings »rod « stammer fra den tidlige arabiske algebra, hvis typeopgaver handlede om en sum penge og dennes kvadratrod; efterhånden som denne oprindelse blev glemt, blev ordet i stedet opfattet simpelt hen som »øsning «. Mere påfaldende er det at senere opgaver på samme tavle kun taler om en enkelt ligeside; det sker i tilfælde hvor kælderens volumen målt med sammenligningsprismet (det er ikke en terning hver gang) skal 
faktoriseres som $p^{3}$ eller som $p^{2} \cdot(p+1)$. Disse to funktioner fandtes der nemlig tabeller over, hvor $p$ netop omtales som »ligesiden «.

Hvis vi sammenligner løsningen af tredjegradsproblemer (det nærværende eksempel er typisk) med andengradsalgebraen ser vi at også den er analytisk: den går ud fra at vi har en løsning og ser så hvad vi kan slutte ud fra den (det samme gælder enhver anvendelse af den simple falske ansats, der netop er en antaget, og endda falsk, løsning). Ellers er det imidlertid kun udenværker terminologi, brugen af tabeller hvis de findes, de gængse regneoperationer - der forener de to.

Andre af den samme tavles opgaver (der alle handler om prismeformede »kældre «) fører til første- eller andengradsproblemer, der løses med de sædvanlige algebraiske metoder. Babylonierne kendte udmærket forskellen: de finder aldrig på at løse et andengradsproblem ved faktorisering, for der havde de en anden (og åbenbart også efter deres egen mening bedre) metode til rådighed. Men forskellen var åbenbart ikke afgørende; den matematiske genre defineredes snarest som »kælderopgaver « på samme måde som BM 13901 behandler genren »kvadratopgaver « uanset at én af opgaverne reduceres til et rektangelproblem. Endnu engang må vi konkludere, at for så vidt skellet mellem »algebra « og »kvasi-algebra « overhovedet svarer til en skelnen som babylonierne ville formulere, var det i hvert fald ikke af større vigtighed for dem. 


\section{ALMENE KENDETEGN}

\section{Tegninger?}

Alle de ovenstående tekster er blevet illustreret med geometriske diagrammer, og kun i et enkelt tilfælde fandtes der et diagram på tavlen.

Så meget $\mathrm{i}$ teksterne er besynderligt $\mathrm{i}$ den traditionelle tolkning og kun forklarligt i en geometrisk tolkning, at en eller anden form for geometri må være involveret. På den anden side er det langt fra sikkert at babylonierne har benyttet sig af tegninger der så ud præcis som de her viste. Tværtimod tyder adskilligt $\mathrm{i}$ teksterne på at de har støttet tanken på meget grove strukturdiagrammer; det blev nævnt på side $57 \mathrm{i}$ forbindelse med skalaskiftet i én retning; fraværet af særlige navne for $L=$ $3 \lambda \operatorname{og} B=21 \beta$ i TMS IX nr. 3 (se side 65) tyder også på at der ikke har været nogen særskilt figur hvorpå de kunne identificeres, således som »fladen 2 « og dens sider $\lambda$ og $\beta$ kunne.

Det er der intet mærkeligt i. Man skal ikke have arbejdet længe med de babyloniske tekster før man kun behøver at lave en meget grov skitse for at kunne følge regningerne; man behøver egentlig slet ikke at indtegne ituskæringer og flytninger, blot man har tegnet rektanglet ved man hvad der er tale om. Som vi kan foretage hovedregning, evt. med nedskrift af et par mellemresultater, således kan vi også lære at lave »hovedgeometri $\ll$.

Vi har en del af de markplaner som de babyloniske landmålere udarbejdede. De har netop karakter af strukturdiagrammer. 
Der er ikke gjort meget for at respektere målestoksforholdene (forskellen mellem Figur 26 og Figur 27 er et eksempel på forskellen mellem det babyloniske diagram og tegningen i korrekt målestok, men et af de mildere), eller for at opnå vinkeltroskab; men man kan altid se hvilke vinkler der anses for "praktisk rette" og derfor indgår i arealmålingen.

Man kan næppe lære hovedgeometri uden først at se og udføre tegnet geometri, så tegninger må have eksisteret. Blot er det ikke praktisk at udføre klippe-klistre-geometri på en lertavle. Man skal meget hellere benytte et redskab som også blev brugt af de første arabertalsregnere i Mellemøsten såvel som de græske geometere: en »støv-abakus«, en plade med støv eller sand hvor man let kan rette og viske ud. ${ }^{[24]}$ Eventuelt kan skolegårdens sand bruges på samme måde.

Støv eller sand synes også at være blevet brugt i skriveundervisningen: fra dennes begyndertrin kender man de tavler der tjente som forlæg for eleverne; men elevøvelserne selv, som på de højere niveauer blev foretaget på lertavler og derfor er velkendte, er der ingen af. Vi behøver derfor ikke undre os over at heller ikke klippe-klistre-geometriens tegninger er blevet bevaret.

${ }^{24}$ Det græske ord ábax, »abakus", er faktisk lånt fra fønikisk, hvor det er afledt fra ordet for »let støv«. 


\section{Algebra?}

Hidtil har vi for nemheds skyld og i overensstemmelse med de fleste matematikhistorikeres sædvane talt om babylonisk "algebra " uden at have taget stilling til om, og i hvilken forstand det er berettiget at bruge dette moderne begreb om deres geometriske teknik.

Samtidig har vi opsamlet en række observationer som kan bruges som grundlag for en stillingtagen til spørgsmålet.

For det første så vi på side 28 i hvilken forstand de babyloniske opgaveformuleringer er ligninger: En kombination af nogle målelige størrelser, hvis samlede måltal oplyses; eller en angivelse af at en kombination har et måltal der falder sammen med eller overstiger en anden kombinations måltal med et bestemt tal.

Dette er ikke helt de ligninger vi er vant til fra matematikundervisningen; de handler jo om tal, ikke om måltal. Men det er på den anden side præcis den slags ligninger vi kender fra alle anvendelser af algebraisk beregning, uanset om det drejer sig om fysik, befolkningsvækst eller økonomi. I det hele taget er det jo ikke muligt at anvende ligninger uden at deres tal repræsenterer målelige størrelser. Vi kan altså med god ret anse de babyloniske opgaveformuleringer for ligninger.

Den babyloniske metode til at løse ligningerne er (med enkelte undtagelser som vi ikke er truffet på i det foregående) analytisk. Deri ligner den vor moderne ligningsbehandling. Den følger endvidere i de fleste tilfælde trin der enten svarer til vore eller som i hvert fald kan forklares i moderne algebra.

Det er disse fællestræk - forekomsten af ligninger, analyse, beslægtede trin - som har ført mange matematikhistorikere til 
at tale ukritisk om babylonisk »algebra " (forført, har kritikere hævdet de sidste 25 år). Men der findes andre.

Ser vi på moderne ligningsalgebra, er der en neutral "grundlæggende repræsentation « (se side 15): tallene. Men denne repræsentation er en tom skal som alle slags målelige størrelser kan puttes ind i: afstande, arealer, priser, vægtfylder, elektriske ladninger, befolkningsgruppers fertilitet, o.s.v. Over for det står den græske brug af analyse i geometrien: de størrelser der optræder repræsenterer ikke, de er lige præcis de geometriske størrelser de giver sig ud for.

Den babyloniske geometriske teknik er på det punkt analog med den moderne talalgebra og ikke med den græske geometriske analyse; som vi har set kan dens længder repræsentere arealer, tal eller købs- og salgsrater - eller eventuelt andre, "sande" længder. Uanset at vi måske synes at geometri - også de målelige størrelsers geometri - er en mindre tom skal end abstrakte tal, er den babyloniske grundlæggende repræsentation funktionelt set tom.

Moderne ligningsalgebra er altså en almen teknik til at finde ved hjælp af den fiktion at vi allerede har fundet (analysen) og en påfølgende manipulation med ukendte størrelser som om de var kendte, altsammen i en funktionelt set tom repræsentation (tal). Det samme kan vi med et lille forbehold (som vi vender tilbage til) og med en anden repræsentation sige om den babyloniske teknik. Hvis moderne ligningsløsning er algebra, må det være rimeligt at henføre de babyloniske opgaveløsninger vi har set i kapitel III og IV til samme overskrift.

Det betyder ikke at der ikke findes store forskelle - blot har disse ikke at gøre med træk som man normalt vil bruge til at 
skelne »algebra« fra »ikke-algebra«.

Den største forskel (bortset fra den naiv-geometriske repræsentation) er at den babyloniske algebra af anden (og højere) grad ikke kunne anvendes i praksis: ikke fordi den i princippet var uegnet, for det var den jo netop ikke; men fordi der ikke fandtes noget problem inden for horisonten som kaldte på anvendelsen af højere algebra. Det gør at samtlige problemer er kunstige, og at alle er konstrueret baglæns, fra kendte resultater - opgaveforfatteren starter $\mathrm{f}$. eks. med at tænke sig et kvadrat med side 10', og regner så ud at summen af de fire sider og arealet er 41'40"; opgaven som han formulerer bliver at komme tilbage (at »skille arealet fra siderne«, som middelalderens og renæssancens regnemestre sagde).

Den slags algebra kender vi godt i vore dage; det er nu engang sådan man laver regnebøger, hvis man vil være sikker på at der findes en fornuftig løsning. Forskellen er at vore kunstige ligninger formodes at træne eleverne i teknikker som derefter kan bruges i mindre kunstige situationer.

Hvad vi derimod ikke kender til er den åbenhed hvormed en del babyloniske tekster refererer til værdien af størrelser som i princippet er ukendte. Men da teksterne med høj sikkerhed skelner mellem givne og blot kendte størrelser og alene bruger de sidste til identifikation og i pædagogiske forklaringer (jfr. note 22), siger denne forskel først og fremmest noget om behovet for et middel til at beskrive proceduren - et alternativ til vores $l, \lambda$ og $L$ fra algebraen og til vores brug af »liniestykket $A B \ll \mathrm{i}$ geometrien. Da teksterne uanset det optrædende »du« antagelig har tjent som »lærerens bog ", kan vi heller ikke udelukke at den aktuelle undervisning i stedet for identifikation ved talværdier 
har peget på tegningen: »den flade«, »længden af det her rektangel«, o.s.v. Ejheller kan vi selvfølgelig bevise det - det nærmeste vi kommer til en gengivelse af den mundtlige undervisning er tekster som TMS XVI (side 27). 


\section{BAGGRUNDEN}

Det vi nu ved om den babyloniske algebra - dens fleksibilitet, dens egnethed som instrument til at løse irrelevante opgaver, den dygtighed hvormed dens udøvere omgikkes den - gør ikke dens eksistens til mindre af en historisk gåde. Da gåden som allerede sagt på side 5 har beholdt sin aktualitet i næsten 4000 år, bliver vi måske klogere på vort eget årtusinde og vort eget årti ved at overveje situationen i den oldbabyloniske kong Hammurapis århundrede.

\section{Skriverskolen}

Den babyloniske matematik var ikke, som den græske, en krævende hobby for højtbegavede velhavere. Den var undervisningsstof i skriverskolen - måske ikke for alle men i hvert fald for nogle af de kommende skrivere.

Ordet »skriver« kan være vildledende. Skriveren skulle selvfølgelig kunne skrive; men han skulle sandelig også kunne regne. Blandt moderne professioner skal han sammenlignes med ingeniøren, bogholderen og notaren, snarere end med den maskineller PC-skrivende sekretær.

Af samme grund er det lettere misvisende at tale om babyloniske matematikere. Det som skriverskolens matematiklærere underviste i var strengt taget ikke matematik men beregning. Det som skriveren skulle finde, både i sine ingeniør- og i sine bogholderfunktioner, var det rigtige tal. Selv de opgaver der ikke kunne bruges i nogen virkelig praksis handler altid om målelige størrel- 
ser, og de spørger altid efter et tal (eller flere), som vi har set; det er i virkeligheden bedre at tale om »ren beregning « end om »ren matematik « (som det skete på side 7) hvis vi vil karakterisere dem.

Af samme grund handler også så mange af opgaverne om opmåling af marker, om køb og salg, om bygning af belejringsramper; faktisk kan man lære meget om babylonisk dagligdag som den så ud i den arbejdende skrivers perspektiv ved at se på hvilken praksis de ubrugelige opgaver foregiver at handle om.

\section{Første formål: træning}

Når man arbejder sig gennem en af de mere komplicerede algebratekster er det fristende at tro på talregningerne - »det skal da nok passe at IGI af 6 $6^{\circ} 56^{\prime} 40^{\prime \prime}$ er $8^{\prime} 38^{\prime \prime} 24^{\prime \prime \prime}$, og hvis det var forkert ville der nok have stået en bemærkning i den moderne tekstudgave « (faktisk er et par skrivefejl i tallene da også stiltiende blevet rettet i det foregående, så alting bør passe). Den læser af det foregående som ikke har været så godtroende men har gennemført alle beregninger på egen hånd er til gengæld blevet en trænet regner i trestalssystemet.

Det illustrerer én af den babyloniske algebras funktioner i skriverskolen: den var et glimrende påskud til at regne med besværlige tal. Skriverskolen skulle jo netop træne kommende praktikere i de nødvendige professionelle færdigheder, og én af dem var ubesværet omgang med trestalssystemet.

Den overvejelse kan overføres til vort århundredes under- 
visning $i$ andengradsligninger. Den har naturligvis aldrig haft til formål at hjælpe eleverne med at kopiere hensigtsmæssigt fra plade eller CDer til et kassettebånd. Til gengæld er reduktionen af komplicerede ligninger og den påfølgende løsning af de fundamentale andengradsligninger ikke nogen dårlig træning i algebraisk manipulation med bogstavsymboler og $\mathrm{i}$ indsættelse af talværdier i formler - det har faktisk vist sig vanskeligt at finde alternativer der var bedre egnet til træningsformålet og samtidig handlede om mere vedkommende problemer. Og grundlæggende forståelse af bogstavmanipulation og indsættelse i formler er noget mange vil få brug for.

\section{Andet formål: standsstolthed}

Træning af nødvendige færdigheder er selvfølgelig et praktisk formål, også når det opnås ved indirekte midler. Men skriverskolens undervisning i ubrugelig beregning havde også et andet kulturelt eller ideologisk - formål: det kan man se ud fra vort almene kendskab til skolen, ikke mindst ud fra de tekster der blev brugt til at opbygge de kommende skriveres stolthed over at være skrivere.

Dem har vi adskillige af fra den oldbabyloniske epoke. De refererer kun i meget begrænset omgang til de praktisk nødvendige rutiner: sådanne færdigheder er simpelthen for elementære, ikke noget man kan være stolt over at beherske. Stolt kunne man derimod være hvis man kunne skrive sumerisk (som på det tidspunkt kun andre skrivere forstod); hvis man kendte til sjældne eller hemmelige betydninger af ordtegnene; o.s.v. 
Der var heller ikke større grund til at være stolt af at man kunne beregne arealet af en rektangulær mark hvis man kendte længde og bredde; selv beregningen af en trapezareal var let nok lært. At finde længde og bredde ud fra deres sum og arealet, det krævede derimod finesse; at finde det ud fra data som dem der gives i AO $8862 \mathrm{nr}$. 2, eller at finde længden af det knækkede målerør ud fra de monstrøse oplysninger i VAT 8532 - det krævede mere endnu. Den der klarer det kan føle sig som en virkelig skriver, som er person der har krav på respekt.

Vi ved intet om i hvilket omfang matematik eller sumerisk er blevet brugt til sortering - én af de funktioner sådanne fag har i den moderne skole. Da skriverskolen ikke var et offentligt skolevæsen med principielt lige adgang for høj og lav, har sorteringsfunktionen nok ikke været så væsentlig som i senere tider. Men også opbygning af standsstolthed kender den nyere tids skole til. Ganske vist har siden renæssancen latinen (og »latiniteten « som symbol på den højere dannelse) været hjørnestenen $i$ embedsapparatets selvbevidsthed, og fra det synspunkt har ingeniørernes matematiske kunnen ofte i sig selv været symbolet på deres kulturelle underlegenhed; men officerer og ingeniører har til gengæld siden det 18. århundrede brugt deres matematiske kunnen - og helst kunnen $u d$ over det nødvendige i professionen - som kernen i deres standsbevidsthed.

Også en analyse af den babyloniske højere matematiks kulturelle funktion kan altså gøre os klogere på vor egen epoke. 


\section{FORHISTORIE OG VIRKNING}

En type forklaring af sociale og kulturelle forhold er gennem deres funktion: Hvis skriverskolen brugte tid på en så åbenbart unødvendig aktivitet som løsning af andengradsligninger, må denne aktivitet have haft nogle vigtige skønt måske mindre åbenbare virkninger. Den type forklaring har vi lige diskuteret.

En anden type - ikke noget alternativ men den anden side af den samme mønt - er forklaringen gennem historisk oprindelse: Hvem fandt på det, og hvornår? Og hvis opfindelsen ikke fandt sted inden for skriverskolens rammer, hvor er ideen så lånt fra, og hvordan skiftede aktiviteten eventuelt karakter ved at blive overført til et nyt miljø og dermed få nye funktioner?

Inden for det sidste par årtier har man lært en del om det 3. årtusindes sumeriske matematik, herunder arealberegninger for rektangler og næsten-rektangulære firkanter - nok til at man med høj sikkerhed kan slutte at når der ikke fra det tredje årtusinde er fundet tavler med algebra-opgaver skyldes det at der ikke var nogen. Det står i modstrid med den traditionelle overbevisning om at alt i Mesopotamien måtte være ældgammelt, og den babyloniske matematik derfor næsten som en selvfølge måtte videreføre den sumeriske - vi er jo i »Orienten «, og i »Orienten« er alt som bekendt ældgammelt og uforanderligt. 


\section{Oprindelsen: Landmålergåder}

Men den oldbabyloniske skriverskoles algebra er altså ikke en videreførelse af gamle skrivertraditioner; den er i stedet et (blandt flere) udtryk for den oldbabyloniske epokes fornyelse af skriverkulturen. Den kunne i princippet være opfundet inden for denne skole; det passer godt med at det grundlæggende vokabular for den praktiske landmåling og regnekunst (»længde«, »bredde «, »ligeside«", IGI) er sumerisk, mens alt hvad der specielt karakteriserer den algebraiske genre (»at lade holde«, o.s.v.) grundlæggende er akkadisk (uanset at en del tekster bruger ordtegn; oftest bruges de nemlig på en måde der utvetydigt viser at de skal læses på akkadisk).

En oprindelse inden for skriverskolen selv passer imidlertid rigtig skidt med kilderne i øvrigt. Især passer de dårligt med den måde hvorpå beslægtet materiale dukker op i græske og middelalderlige kilder. Analyserer man det, kommer man frem til følgende billede (argumentationen er kompleks og inddrager nøje analyse af mange kilder; der er ikke mulighed for at gennemgå den her):

Landmålere fra det central Iraq, det akkadiske kerneområde antagelig ikke kun derfra, men i hvert fald der - havde en tradition for geometriske gåder. Den slags professionelle gåder kender vi også fra andre af den før-moderne verdens »matematiske praktikere - specialister i handelsregning, bogholderi, o.s.v. - der blev oplært som lærlinge og ikke i en lærd skole. Som eksempel kan tjene »de hundrede fugle«, der dukker op i utallige opgavesamlinger fra den kinesiske, indiske, arabiske og europæiske middelalder: 
En mand gik til markedet og købte 100 fugle for hundrede dinarer. En gås kostede 3 dinarer, en høne 2 dinarer, og af kyllinger fik han 3 pr. dinar. Fortæl mig, hvis du dur til noget som regnemester, hvad han købte! ${ }^{[25]}$

Der findes mange svar: 5 gæs, 32 høns, og 63 kyllinger; 10 gæs, 24 høns, og 66 kyllinger; o.s.v. ${ }^{[26]}$ Når opgaven fungerer som gåde er det imidlertid ikke vigtigt at finde den komplette løsning, ejheller måske at give et bevis; den der kan give et rigtigt svar viser sig derved som en kyndig regnemester, »til de ukyndiges forbløffelse« (som det hedder i en lærebog for praktiske regnere fra 1545).

Ofte bygger løsningen af den slags opgaver på et uventet trick (her f.eks. at man ser at man for hver gås skal købe tre kyllinger - det giver 4 fugle for 4 dinarer; og for hver 2 høns ligeledes 3 kyllinger - 5 fugle for 5 dinarer).

Den slags »underholdningsopgaver « (som de kom til at hedde efter at de blev overtaget i en matematiske kultur baseret på skoleundervisning, hvor deres oprindelige funktion blev reduceret

\footnotetext{
${ }^{25}$ Der er tale om en "gennemsnitsvariant«. Priserne på de enkelte fuglesorter (og sorterne selv, der ikke altid er fugle) kan variere; men der er normalt tale om 100 dyr og 100 møntenheder, normalt også om tre sorter hvoraf én koster mindre end møntenheden og to koster mere. ${ }^{26}$ En opgave: Find det fuldstændige løsningssæt (med eller uden negative tal, der kan stå for at manden sælger), og vis at det er fuldstændigt på de valgte betingelser. Det gjorde den arabiske matematiker Abū Kāmil omkring år 900, og benyttede lejligheden til i sin indledning at håne de praktikere der ikke besad teoretisk forståelse men blot stak én løsning ud - og som altså ikke forstod problemet som en matematikopgave men som en gåde.
} 
til underholdning) havde en dobbelt funktion i deres oprindelige miljø: dels var de et element $\mathrm{i}$ uddannelsen - også i en moderne skole kan løver der spiser 4 matematiklærere i timen være en inspirerende afveksling fra børn der får 3 bolsjer om dagen; dels, og først og fremmest (fordi de specielle tricks sjældent havde nogen funktion i den praktiske regning), var de med til at opbygge professionens selvbevidsthed over for »de ukyndige « - ganske svarende til hvad der blev sagt om den kulturelle funktion af sumerisk og algebra for de babyloniske skrivere.

Engang mellem 2200 og 1800 f.v.t. fandt de akkadiske landmålere på det som senere netop kom til at hedde »den akkadiske metode«, altså på den kvadratiske komplettering; og omkring 1800 f.v.t. cirkulerede der blandt dem en lille række af gåder hvis løsning var baseret på dette trick. Karakteristisk var at de altid handlede om størrelser der umiddelbart indgik i figurerne, f. eks. »siden« eller »alle fire sider « af en kvadratisk mark, aldrig om »siden taget 3 gange « eller » $1 / 3$ af arealet .

Benytter vi for et kvadrat symbolet ${ }_{4} s$ for »alle fire sider « og $Q$ for arealet, for et rektangels areal symbolet $A$ og for dets diagonal symbolet $d$, omfattede rækken af gåder bl.a. antagelig følgende (der var også nogle der handlede om to kvadrater, samt én om en rektangeldiagonal som vi skal træffe på side 141):

$$
\begin{aligned}
& S+Q=110 ;{ }_{4} S+Q=140 ; \quad Q-S=90 ; \quad Q-{ }_{4} S=60 \text { (?) ; } \\
& l+b=\alpha, A=\beta ; \quad l-b=\alpha, A=\beta ; \\
& l+b=\alpha,(l-b)+A=\beta ; \quad l-b=\alpha,(l+b)+A=\beta ; \\
& d=\alpha, A=\beta \text {; }
\end{aligned}
$$

Disse opgaver lånte den oldbabyloniske skriverskole, og brugte dem som udgangspunkt for sin opbygning af algebraen som 
matematisk disciplin. Men den overtog ikke gådetraditionen ubearbejdet; hvor en gåde, for at lyde slående, netop skal handle om de umiddelbart give størrelser (siden, alle siderne, o.s.v.), så er det naturlige for en skole systematisk variation af koefficienterne - naturligt ikke mindst for den særdeles systematiske mesopotamiske skole, og samtidig nødvendigt hvis opgaverne skulle tjene som påskud til regning med besværlige tal; og hvor det er nærliggende i en gåde at lægge ud med det umiddelbart kendte (siden) og derefter gå over til det beregnede (arealet), så er det selvfølgelige i skolen allerede at tænke på løsningsmetoden under formuleringen, og derfor omtale det areal først som bagefter skal udstyres med et »fremspring «. Det systematiske arbejde havde en dobbelt konsekvens: på den ene side muliggjorde det nye opdagelser (af hvilke skalaskiftet i én retning er den simpleste og faktoriseringen af trediegradsproblemer en af de mere raffinerede) og dermed løsning af mere indviklede opgaver. På den anden side blev løsningen af de grundlæggende opgaver hverdagsagtig og ikke i sig selv noget den professionelle stolthed kunne bygge på; den mulighed for løsning af indviklede opgaver der åbnede sig blev derfor samtidig et behov, set i forhold til algebraens kulturelle funktion. Endelig må man formode at det er skriverprofessionens orientering mod en bred praksis der førte til forsøg på at konstruere opgaver på andre felter der kunne løses ved hjælp af den algebraiske teknik - altså, skønt »forskning « ikke var skriverskolens opgave eller mål, til udforskning af muligheden for repræsentation. Det er dermed overførslen til skriverskolen der forvandler den geometriske klippe-klistre-teknik til kernen $i$ en egentlig algebra.

Og så blev løsningerne selv anderledes: hvor gådetraditionens 
normalkvadrat havde haft siden 10, foretrak skolen 30'; når skolen en enkelt gang beholdt 10, ændredes tallets størrelsesorden til $10^{\prime}$. Og som nævnt på side 35 blev den hypotetiske »nogen « der formulerede gåden omtolket til lærerens »jeg «.

Omtolkningen af $10^{\circ}$ som 10’ så vi i BM 13901 nr. 23 (side 84); denne sære opgave viser sig at være en ledeforstening for inspiration fra landmålertraditionen. Den har ikke blot beholdt den oprindelige side (bortset fra størrelsesordenskiftet), men også interessen for »alle fire sider " og leddenes oprindelige orden. Som nævnt er også hele sprogbrugen arkaiserende, et spil på praktikersprogbrug. Den er, uden al tvivl, en villet henvisning til forbindelsen til den gamle tradition og dens gåder - en slags »sidste opgave før jul«.

\section{Videre liv}

Den oldbabyloniske periode endte meget brat i 1600 f.v.t. med en hittitisk plyndring af Babylon og en påfølgende magtovertagelse af krigeriske barbarstammer. Skriverskolen bukkede under i processen, og skriveruddannelsen overlevede kun som lærlingeuddannelse.

Også den højere matematik bukkede under. Praktisk beregning var der stadig brug for, men skrivernes standsstolthed fandt sig et andet fundament (tilhørsforholdet til en hæderværdigt gammel tradition af litterært tilsnit). Fra en periode på mere end tusind år findes der ingen algebraiske kileskrifttekster. Det siger ganske vist ikke så meget i sig selv, for der findes så godt som ingen matematik i det hele taget; men når matematiske tekster 
dukker op igen kan man se på terminologien hvilke discipliner der i mellemtiden har været udøvet af sumerisk-kyndige skrivere og hvilke der er kommet ind i miljøet udefra.

Hvor udefra fremgår ikke entydigt af de senbabyloniske matematiske tekster selv, skønt en videreført landmålertradition er det rimeligste gæt. Derimod lader andre kilder ingen tvivl om at den samme tradition som i sin tid inspirerede den oldbabyloniske skolealgebra levede videre uanset skolealgebraens forsvinden.

Det bedste vidnesbyrd er en arabisk landmålingshåndbog, antagelig skrevet omkring år 800 . Den indeholder bl. a. alle de opgavetyper som ovenfor blev henregnet til den oprindelige gådetradition; ikke mindst har den opgaven med de fire sider og arealet, endda med den oprindelige rækkefølge af leddene og løsningen 10. Den har også bevaret hele det komplekse skift mellem forskellig grammatisk person og tid, samt den hypotetiske "nogen « der også dukker op i nogle af de tidligste skoletekster. Opgaver fra denne tradition bliver ved med dukke op i de kommende århundreder - »de fire sider og arealet « med denne rækkefølge og løsning 10 således (for vistnok sidste gang) i Luca Paciolis Summa de arithmetica fra 1494.

I den græske antikke matematik dukker andengradsproblemer kun op nogle få gange. Et af disse steder er dog påfaldende. I et skrift kendt som Herons geometri, og som ud over nogle få lån fra Herons egne arbejder indeholder diverse ældre landmålermatematik, genfinder man »de fire sider og arealet«, blot med den variant at »de fire sider « er blevet til »omkredsen «; til gengæld beskrives løsningen (der følger princippet fra Figur 12) så præcist geometrisk at man selv uden tilstedeværelsen af en 
tegning kan finde ud af hvad der skal være op og ned på figuren; bredden af det rektangel der repræsenterer $4 s$ omtales også udtrykkelig som 4 fod.

Siden opdagelsen af den babyloniske algebra har det været en hyppig antagelse at dele af den græske geometri (mere præcist, Euklids Elementer, bog II, sætning 1-10) skulle være en oversættelse af resultater fra den babyloniske algebra til geometrisk sprog. Det var der en del problemer i - bl.a. løser Euklid jo ingen opgaver, han beviser sætninger. På den anden side synes den geometriske tolkning af den babyloniske teknik at støtte hypotesen om en sammenhæng. En sammenstilling af Euklids sætninger med hvad man kan tilskrive den oprindelige gådetradition giver nu et forbløffende resultat: alle de ti sætninger kan forbindes direkte med landmålergåderne, som eftervisninger af at de traditionelle »naive « metoder er gode nok. På den anden side er der intet hos Euklid (eller de øvrige græske matematikere) der kan knyttes til det som skriverskolen selv udviklede; historisk set var skriverskolens matematik en blindgyde, uanset dens høje niveau - eller, snarere, netop på grund af et niveau der kun kunne trives så længe skolen selv overlevede.

Sin største betydning for moderne matematik fik landmålertraditionen dog nok gennem sin påvirkning af den arabiske middelalders algebra. Også den udsprang tilsyneladende af en gådetradition; typeopgaverne handlede som nævnt på side 102 om en sum penge og dens kvadratrod, og løsningerne fulgte skemaer uden bevis. Således i følgende tilfælde:

En pengesum og 10 af dens kvadratrødder bliver 39. Halver rødderne, gang de 5 der fremkommer med sig selv, det bliver 25 . Læg 25 til 39, det bliver 64. Tag kvadratroden, det bliver 8. Subtraher 
halvdelen af kvadratrødderne, du har så 3 tilbage: det er pengesummens kvadratrod, og pengesummen selv er 9 .

Allerede den første forfatter af et værk om algebra som vi kender (al-Khwārizmī, fra det tidlige 9. århundrede) var dog ikke tilfreds med sådanne skemaer uden forståelighed eller bevis; han lånte derfor geometriske beviser fra landmålertraditionen, svarende til Figur 12, Figur 14, Figur 22 - og, allerførst og mest slående, den særegne Figur 34. I løbet af nogle århundreder blev disse beviser forstået som kernen i hvad algebra var; den gamle landmålergeometri erobrede disciplinen indefra, og da den blev oversat til latin i den senere middelalder blev census, oversættelsen af »pengesum «, opfattet som et andet ord for »kvadrat«. Det skete i vekselvirkning med Euklids Elementer, bog II - men også det var jo altså en efterkommer af landmålergåderne.

Skønt lertavlernes algebra i sig selv var en monumental blindgyde, var de grundprincipper som den lånte fra de ulærde landmålere altså det stik modsatte. Uden landmålergåderne som udgangspunkt er det svært at forestille sig hvordan den moderne matematik havde set ud. Som det er blevet sagt om Vorherre selv: Hvis Han ikke eksisterede, måtte man opfinde Ham. 


\section{MORALE}

En morale? Hvordan kan det lade sig gøre? Hvad har matematikken og dens historie med moral at gøre?

$\mathrm{Nu}$ er jo en morale ikke helt det samme som en moral. En morale er en overvejelse som kommer efter en historie, en overvejelse af »hvad vi kan lære af den « angående vor fremtidige adfærd. I den forstand har det været almindelig sædvane at ikke blot historier men også historie sigtede mod en underforstået morale - sædvane lige siden Kong Salomons skrivere begyndte at samle materialet om begivenhederne i Kong Sauls og Kong Davids tid.

Og i den forstand har også matematikhistorie, og matematikhistorier, deres morale. Den første fortolkning af den babyloniske algebra havde det underforståede budskab at »de « havde den samme slags algebra som »vi«; blot manglede de den algebraiske symbolik der har muliggjort vore yderligere fremskridt, og de havde endnu ikke »opdaget « de negative tal (hvad der i sekundærlitteraturen som nævnt blev til at de havde opdaget dem). »De« var ikke så langt fremme som »vi«, men de var på vej: på den eneste vej, vejen frem mod os. Og med nærliggende følgeslutninger: den vej vi er på, den eneste vej, er garantien for at hvad vi gør er fremskridtet selv, som alle andre - andre kulturer, og skoleelever der endnu ikke har fundet frem til den rigtige vejskal lære at gå. Med endnu en følgeslutning, ikke helt så nærliggende måske: Når det gælder i matematikken, så gælder det nok også på civilisationens øvrige felter. »Vi« er fremskridtet selv. 
Det kan vanskeligt være budskabet i den her præsenterede læsning af de babyloniske tekster. Nok kom den babyloniske matematik ofte forbløffende nær på vores - antagelig nærmere end nogen anden »fremmed « matematisk kultur (fra den græske og den arabiske matematik har vi lært for direkte til at vi kan kalde dem fremmede). Men alligevel var der store forskelle, i metoder, i problemstillinger, og i tænkemåder. Hvad vi ser er at matematik kan tænkes på mange måder, og at vi gør klogt i at lytte til partneren (uanset om der er tale om historikerens partner, den fremmede kultur, eller lærerens partner, eleven) før vi lægger os fast på hvordan den/hun/han nødvendigvis har tænkt og skal tænke. Hvis matematik kan tænkes på flere måder, er der ingen garanti for at vores er den eneste rigtige; men ved at lytte kan vi blive klogere på hvorledes vi selv tænker, og bedre egnet til at vurdere om vores vej er én af de frugtbare - måske også til at vurdere hoad den er frugtbar til.

Det fremskridt der kan findes i matematikkens udvikling er ikke nogen ensrettet motorvej; det er, med et billede som den tyske matematikhistoriker Moritz Cantor formulerede i forrige århundrede, et flodlandskab med talrige strømme: strømme som, alt $i$ alt og med mange bugter, med sammenfletninger og spaltninger, har en tendens til at løbe i samme retning, mod det samme hav. Findes der fremskridt i civilisationen som helhed, har det samme karakter. 


\section{BIBLIOGRAFISK OVERSIGT}

De fleste af de babyloniske matematiske tekster er udgivet i:

O. Neugebauer, Mathematische Keilschrift-texte. I-III. (Quellen und Studien zur Geschichte der Mathematik, Astronomie und Physik. Abteilung A: Quellen. 3. Band, erster-dritter Teil). Berlin: Julius Springer, 1935, 1935, 1937. Genoptryk Berlin etc.: Springer, 1973, og $\mathrm{i}$

F. Thureau-Dangin, Textes mathématiques babyloniens. (Ex Oriente Lux, Deel 1). Leiden: Brill, 1938.

Med de nedennævnte undtagelser findes alle de her benyttede tekster i begge disse værker.

En yderligere samling af tekster findes i

O. Neugebauer \& A. Sachs, Mathematical Cuneiform Texts. (American

Oriental Series, vol. 29). New Haven, Connecticut: American Oriental Society, 1945.

Herfra er teksten YBC 6967 taget. Endelig er alle tekster betegnet TMS taget fra

E. M. Bruins \& M. Rutten, Textes mathématiques de Suse. (Mémoires de la Mission Archéologique en Iran, XXXIV). Paris: Paul Geuthner, 1961.

De tre første udgaver er pålidelige, også i deres oversættelser og kommentarer; dog gør man ved brug af Neugebauers Mathematische Keilschrift-Texte klogt $i$ at konsultere de lister over rettelser der findes i bind II og III - et pionerarbejde kan ikke undgå at udkaste hypoteser og foreslå fortolkninger der ved nøjere efterprøvelse må korrigeres. Det siger sig selv at kommentarerne i alle tre værker bygger på den traditionelle aritmetiske tolkning; 
denne blev jo netop skabt af Neugebauer og Thureau-Dangin, feltets fædre.

Udgaven af Susa-teksterne er langt mindre pålidelig. De franske oversættelser og den matematiske kommentar er, i værste forstand, fantasifulde; end ikke oversættelserne af ordtegn til akkadisk er til at stole på (for eksempel oversættes ordtegnet for »at tilføje« som om der stod »at lægge i bunke«, for at nævne et simpelt eksempel); faktisk bør man kontrollere alt på selve tegningen af kileskriftteksten. (Med andre ord: udgaven er så godt som ubrugelig for ikke-specialister, selv for matematikhistorikere uden indgående kendskab til den babyloniske tradition).

En fyldig og pædagogisk indføring i hvad der var kendt om den babyloniske matematik som helhed i 1959 er

Kurt Vogel, Vorgriechische Mathematik. II. Die Mathematik der Babylonier. (Mathematische Studienhefte, 2). Hannover: Hermann Schroedel / Paderborn: Ferdinand Schöningh, 1959.

Den der læser russisk kan have stort udbytte af
A. A. Vajman, Šumero-vavilonskaja matematika. III-I Tysjačletetija do n. e. Moskva: Izdatel'stvo Vostočnoj Literatury, 1961.

En uhyre detaljerig præsentation af både det 3. og det 2. årtusindes mesopotamiske matematik er

Jöran Friberg, "Mathematik". Reallexikon der Assyriologie und vorderasiatischen Archäologie, Bd. VII, side 531-585. Berlin: W. de Gruyter, 1990.

En kortere oversigt med større vægt på den kulturhistoriske sammenhæng er

Jens Høyrup, "Babylonian Mathematics”. Companion Encyclopedia 
of the History and Philosophy of the Mathematical Sciences, Bd. I, side 21-29. London: Routledge, 1994.

En fyldig argumentation for hvorfor den traditionelle tolkning af den babyloniske algebra ikke holder og for nødvendigheden af en geometrisk læsning, baseret på nøje analyse af mange tekster, er

Jens Høyrup, "Algebra and Naive Geometry. An Investigation of Some Basic Aspects of Old Babylonian Mathematical Thought". Altorientalische Forschungen 17 (1990), 27-69, 277-369.

»Landmåleralgebraens« historie, med analyse af de kilder den bygger på, diskuteres i

Jens Høyrup, "The Four Sides and the Area'. Oblique Light on the Prehistory of Algebra", i Ronal Calinger (udg.), Vita Mathemata: Historical Research and Integration with Teaching, side 45-65. Washington, D.C.: The Mathematical Association of America, 1996.

Sidstnævnte artikel blev desværre aldrig udsendt til korrekturlæsning, og den er derfor fuld at trykfejl. 


\section{APPENDIX: OPGAVER OVERLADT TIL LFSEREN}

De opgaver der blev præsenteret i kapitlerne II-V var så forskellige i karakter at det var nødvendigt at forsyne dem alle med en forklaring - ofte en ganske fyldig og detaljeret kommentar. For at lade den læser der ønsker det have fornøjelsen selv at trænge igennem nogle oldbabyloniske tekster bringer dette appendix nogle opgaver der enten kun oversættes eller kun ledsages af den nødtørftigste vejledning. Nogle men ikke alle er modstykker til opgaver der er gennemgået i det foregående og kommer fra de samme tavler.

\section{TMS XVI nr. 2}

13. 4.-delen af bredden til det hvormed længden overstiger bredden, at tilføje,

14. $15^{\prime} . \mathrm{Du}, 15^{\prime}$ til 4 løft, 1 ser du, hvad er det?

15. 4 og 1 sæt.

16. 15 opsplit. $10^{\prime}$, overskridelsen, og $5^{\prime}$ der blev tilføjet sæt. 20', bredden,

17. til 10', overskridelsen, tilføj, 30’ længden, og $20^{\prime}$, til at udrive, sæt. 5' til 4 løft,

18. $20^{\prime}$ ser du. $20^{\prime}$, bredden, til 4 løft, $1^{\circ} 20^{\prime}$ ser du.

19. 30', længden, til 4 løft, 2 ser du. 20', bredden,

20. fra $1^{\circ} 20^{\prime}$ udriv, 1 ser du. 1

21. fra 2, længderne, udriv, 1 ser du, hvad er det?

22. Fra 4, fra fjerdedelen, 1 udriv, 3 ser du. IGI af 4 fraspalt, $15^{\prime}$ ser du. 
23. 15 1 til 3 løft, $45^{\prime}$ ser du, så meget som der er af bredder sæt. Sæt til at udrive.

24. 1 så meget som der er af længder sæt. [...] 1 tag, til 1 længde

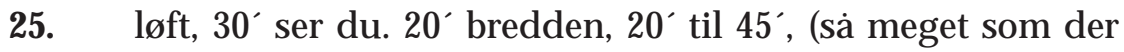
er af) bredder, løft,

26. 15` ser du, 15` til 15` tilføj, 30` ser du, 30` længden.

Kommentar: Jfr. samme tavles nr. 1, side 27.

\section{TMS VII nr. 1}

1. 4.-delen af bredden til længden har jeg tilføjet, dets 7.-del indtil 10 er jeg gået,

2. $\quad$ så meget som bunken af længde og bredde. Du, 4 sæt; 7 sæt;

3. $\quad 10$ sæt. $5^{\prime}$ til 7 løft, $35^{\prime}$ ser du.

4. 30' og 5' udskil. 5', skridtet, til 10 løft,

5. $50^{\prime}$ ser du. $30^{\prime}$ og $20^{\prime}$ sæt. $5^{\prime}$, skridtet, til 4, fra fjerdedelen af bredden,

6. Iøft: $20^{\prime}$ ser du, $20^{\prime}$ bredden. $30^{\prime}$ til 4 , fra fjerdedelen,

7. løft, 2 ser du. 2 sæt, længder. 20’ fra 20`udriv,

8. og fra $2,30^{\prime}$ udriv, $1^{\circ} 30^{\prime}$ ser du.

9. Fra 4, fra fjerdedelen, 1 udriv, 3 ser du.

10. IGI af 3 fraspalt, $20^{\prime}$ ser du. $20^{\prime}$ til $1^{\circ} 30^{\prime}$ løft:

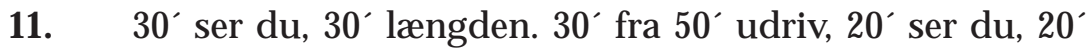
er bredden.

12. Vend tilbage. 7 til 4 , fra fjerdedelen, løft, 28 ser du.

13. 10 fra 28 udriv, 18 ser du. IGI af 3 fraspalt,

14. 20` ser du. 20` til 18 løft, 6 ser du, 6 (for) længden.

15. 6 fra 10 udriv, 4 (for) bredden. 5' til 6 løft, 
16. 30` er længden. 5’ til 4 løft, 20` ser du, 20` er bredden.

Kommentar: Jfr. samme tavles nr. 2, side 36.

\section{VAT 8389 nr. 1}

Fs I

1. Fra 1 BUR, 4 GUR korn har jeg opkrævet.

2. Fra 1, anden, BUR, 3 GUR korn har jeg opkrævet.

3. Kornet overstiger kornet med $8^{\circ} 20^{\prime}$.

4. Mine jordlodder har jeg lagt i bunke, 30 .

5. Mine jordlodder hvad?

6. $30^{\circ}$, en BUR, sæt. $20^{\circ}$, kornet han har opkrævet, sæt.

7. $30^{\circ}$, den anden BUR, sæt.

8. 15 , kornet han har opkrævet, sæt.

9. $8^{\circ} 20^{\prime}$, hvormed kornet overstiger kornet, sæt,

10. og 30', bunken af fladerne af jordlodderne, sæt.

11. 30', bunken af fladerne af jordlodderne,

12. til to bræk: 15 .

13. 15 og 15, indtil to gange sæt.

14. IGI af $30^{\circ}$, en BUR, fraspalt: $2^{\prime \prime}$.

15. 2" til 20", kornet han har opkrævet,

16. løft, 40` det falske korn; til $15^{`}$ som indtil to gange

16a. du har sat,

17. løft, 10` skal dit hoved beholde.

18. IGI af 30 ', den anden BUR, fraspalt, $2^{\prime \prime}$.

19. 2" til 15', kornet som han har opkrævet,

20. løft, 30` det falske korn; til 15` som indtil to gange

20a du har sat, løft, 7`30.

21. 10 som dit hoved beholder

22. overskrider $7 ` 30$ med hvad? Med $2 ` 30$ overskrider det. 
23. $2 ` 30$ der overskrider, fra $8 ` 20$

24. hvormed kornet overskrider kornet

Fs II

1. udriv: 5550 efterlader du.

2. 5 50 som du har efterladt

3. skal dit hoved beholde.

4. $40^{\prime}$, forandringen(?) og 30' forandringen(?)

5. $\quad$ læg i bunke: $1^{\circ} 10^{\prime}$, IGI kender jeg ikke.

6. Hvad til $1^{\circ} 10^{\prime}$ skal jeg sætte

7. som giver mig 5 50 som dit hoved beholder?

8. 5 ' sæt. $5^{\prime}$ til $1^{\circ} 10^{\prime}$ løft,

9. $5 \backslash 50$ giver det dig.

10. 5 som du har sat, fra 15 som indtil to gange

11. du har sat, fra den ene riv ud,

12. til den anden tilføj.

13. Den første er $200^{\circ}$, den anden er $10^{\circ}$.

14. 20 er fladen af den første jordlod, 10` er fladen af den anden jordlod.

15. Hvis 20 er fladen af den første jordlod,

16. 10 fladen af den anden jordlod, deres korn hvad?

17. IGI af $30^{\circ}$, en BUR, fraspalt: $2^{\prime \prime}$.

18. 2" til 20', kornet som han har opkrævet,

19. løft, 40’; til 20', fladen af den første jordlod,

20. løft, 13`20 kornet fra 20`, fladen af jordlodden.

21. IGI af 30 , , den anden BUR, fraspalt: $2^{\prime \prime}$.

22. 2" til 15', kornet som han har opkrævet, 30"

23. 30' til 10', fladen af den anden jordlod,

24. løft, 5 kornet fra 10', fladen af den anden jordlod.

25. 13`20, kornet fra den første jordlod,

26. overstiger 5', kornet fra den anden jordlod,

27. med hvad? Med 8`20 overstiger det. 
Opgaven står på én af to sammenhørende tavler, hvor i alt 10 opgaver handler om fæsteafgiften fra to jordlodder. Af den ene jordlod betales der en afgift på 4 GUR korn pr. BUR, af den anden 3 GUR pr. BUR. I den aktuelle opgave oplyses i øvrigt det samlede areal af de to jordlodder - 30 BUR - og forskellen mellem den totale afgift fra de to marker - 8`20 sìtA. I andre opgaver er $\mathrm{f}$. eks. de to arealer givet, eller forskellen mellem arealerne og den samlede afgift.

Enhederne BUR og GUR er som nævnt på side 16 enheder fra det praktiske liv; for at kunne regne i positionssystemet måtte man omsætte størrelser i sådanne mål til grundenhederne SAR og SìLA (1 BUR = 30` SAR, 1 GUR = 5` SìLA); som vi ser opgives forskellen mellem de to afgifter allerede i sìLA.

En moderne læser undrer sig måske over at de to fæsteafgifter, som i linie I.1-2 opgives i GUR (pr. BUR), omsættes til silLA i linie I.6-7 uden multiplikation; ellers springer teksten jo ikke nogen detalje over. Årsagen er at omsætningen sker ved hjælp af en tabel; netop fordi sådanne omsætninger var så almindelige besad de babyloniske skrivere tabeller der ikke blot oversatte de praktiske enheder selv men også deres multipla til grundenhederne. Derimod havde de ingen kombinerede omsætningstabeller, så den endelige omsætning til sìLA pr. SAR krævede en beregning.

Den moderne læser vil måske også undre sig over at teksten ikke én gang for alle omsætter enheden BUR og finder dens IGI. Forklaringen er igen at teksten beskriver den babyloniske regneteknik: Regneren skriver på en lille kladde-lertavle i rækkefølge de tre tal 20 (20` SìLA pr. BUR), 30 (30“ SAR pr. BUR) og 2 (2", IGI af 30'), og derefter, ved hjælp af multiplikationstabellen, produktet $40\left(20^{\prime} \cdot 2^{\prime \prime}=40^{\prime}\right.$ SìLA pr. SAR $)$. 
Som tip til forståelse af fremgangsmåden kan følgende tilføjes: I første omgang beregnes det hvad forskellen mellem de to afgifter ville være hvis de to jordlodder var lige store, altså 15`SAR hver. Den forskel er ikke stor nok - der mangler 2`30 sìLA - og altså må den første jordlod gøres større. Men hver gang vi overfører en SAR fra den anden til den første jordlod vokser forskellen med $40^{\prime}+30^{\prime}$ SìLA (de to »forandringer « i II. $4^{[27]}$ ); hvor mange SAR der i alt skal overføres kan så findes ved division.

I sidste del af opgaven gøres der prøve. Det er ikke ualmindeligt i babyloniske matematiske tekster, skønt det på den anden side ikke er hovedreglen.

\section{VAT 8390 nr. 1}

\section{Fs 1}

1. Længde og bredde har jeg ladet holde: 10 ` fladen..

2. Længden med sig selv har jeg ladet holde:

3. En flade har jeg bygget.

4. $\quad$ Så meget som længden overstiger bredden med

5. har jeg ladet holde, indtil 9 har jeg gentaget det,

6. (det er) så meget som den flade længden sammen med sig selv

7. lades holde.

8. Længde og bredde hvad?

\footnotetext{
${ }^{27}$ Tavlen er beskadiget på det kritiske sted, så det er usikkert hvilket ord der står; men de rester af tegn der kan ses kunne stamme fra et ord der betyder »forandring «, men som i øvrigt ikke kendes fra matematiske tekster. Hvilket ord der faktisk står berører dog ikke tolkningen af den matematiske procedure.
} 
9. 10` fladen sæt,

10. og 9 hvortil han har gentaget sæt.

11. Ligesiden af 9 hvortil han har gentaget hvad? 3 .

12. 3 til længden sæt.

13. 3 til bredden sæt.

14. Eftersom »så meget som længden overstiger bredden med

15. har jeg ladet holde«, har han sagt,

16. 1 fra 3 som du har sat til bredden

17. udriv: 2 efterlader du.

18. 2 som du har efterladt, til bredden sæt.

19. 3 som til længden du har sat,

20. til 2, som til bredden du har sat, løft, 6 .

21. IGI af 6 fraspalt: $10^{\prime}$.

22. $10^{`}$ til $10^{`}$, fladen, løft, $1 ` 40$.

23. Ligesiden af 1`40 hvad? 10.

Fs II

1. $\quad 10$ til 3 som til længden du har sat

2. $\quad 1 ø f t, 30$ er længden.

3. 10 til 2 som til bredden du har sat

4. løft, 20 er bredden.

5. Hvis 30 længden, 20 bredden,

6. fladen hvad?

7. 30, længden, til 20, bredden, løft, 10` fladen.

8. 30, længden, sammen med 30 lad holde: 15 .

9. 30, længden, overstiger 20, bredden, med hvad? Med 10 overstiger den.

10. 10 sammen med 10 lad holde: $1 ` 40$.

11. $1 ` 40$ til 9 gentag: 15 fladen.

12. 15` fladen er så meget som 15`, den flade som længden

13. med sig selv lades holde.

Som støtte til tolkningen kan en figur gøre nytte (Figur 43). Så 
skulle teksten være nogenlunde selvforklarende - specielt hvis man sammenligner med BM 13901 nr. 10 (side 52).

Værd at lægge mærke til er spillet mellem de forskellige "multiplikative" operationer: at lade holde, at løfte, og at gentage; at vi ved at lade holde faktisk konstruerer (»bygger«) påpeges i I.3, som vi også har set i AO 8862 nr. 2 (side 67).

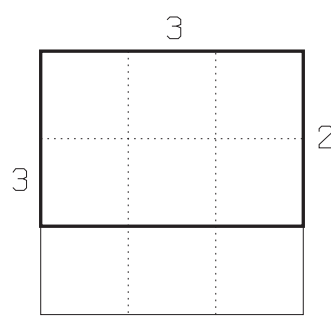

Figur 43. Geometrien i VAT $8390 \mathrm{nr}$. 1. Af særlig interesse er brugen af løftning i I.20 og II.7: Nok er der tale om rektangler, men de findes allerede, der er ikke brug for at konstruere dem. Derfor udregnes arealet blot.

\section{VAT 8520 nr. 1}

Fs

1. 13.-delen af bunken af igûm og igibûm

2. til 6 har jeg gentaget, fra det indvendige af igûm

3. har jeg revet ud: 30` har jeg efterladt. 1 fladen. Igûm og igibûm hvad?

4. Eftersom »trettendedelen af bunken af igûm og igibûm

5. til 6 har jeg gentaget: fra det indvendige af ighm

6. har jeg revet ud: $30^{\prime}$ har jeg efterladt «, har han sagt,

7. 13, fra trettendedelen, sæt; 6 hvortil han gentog sæt;

8. 1, fladen, sæt; og 30' som han efterlod sæt.

9. Fra 13, fra trettendedelen, 6 til hvilket han gentog

10. riv ud. 7 efterlader du.

11. 7 som du efterlader og 6 hvortil du gentog

12. skal dit hoved beholde.

13. 7 til 6 løft, 42 til 1, fladen, løft, 42 . 
14. 42 skal dit hoved beholde.

15. 13, fra trettendedelen, til 30` som han efterlod

16. løft, $6^{\prime} 30^{\prime}$ til to bræk: $3^{\circ} 15^{\prime}$.

17. $3^{\circ} 15^{\prime}$ sammen med $3^{\circ} 15^{\prime}$ lad holde: $10^{\circ} 33^{\prime} 45^{\prime \prime}$.

18. Til $10^{\circ} 33^{\prime} 45^{\prime \prime}, 42$ som dit hoved beholder

19. tilføj, $52^{\circ} 33^{\prime} 45^{\prime \prime}$.

20. Ligesiden af $52^{\circ} 33^{\prime} 45^{\prime \prime}$ hvad? $7^{\circ} 15^{\prime}$.

21. $7^{\circ} 15^{\prime}$ og $7^{\circ} 15^{\prime}$, dets modstykke, tegn:

22. $3^{\circ} 15^{\prime}$, det holdende, fra det ene udriv, til det andet tilføj:

23. Det første er $10^{\circ} 30$, det andet er 4 .

24. Hvad til 7, som dit hoved beholder, skal jeg sætte,

25. som $10^{\circ} 30^{\prime}$ giver mig? $1^{\circ} 30^{\prime}$ sæt. $1^{\circ} 30^{\prime}$ til 7 løft,

26. $10^{\circ} 30^{\prime}$ giver det dig. $1^{\circ} 30^{\prime}$ som du har sat er igûm.

27. IGI af 6, som dit hoved holder, fraspalt, 10’.

28. 10' til 4 løft, 40’ er igibûm.

29. Eftersom $1^{\circ} 30^{\prime}$ er igûm, 40’ er igibûm, fladen er hvad?

30. 1'30', igĥum, til 40', igibûm, løft, 1 er fladen.

31. $1^{\circ} 30$, igĥm, og 40’, igibûm, læg i bunke: $2^{\circ} 10^{\prime}$.

Rs

1. Trettendedelen af $2^{\circ} 10^{\prime}$ hvad? $10^{\prime}$.

2. 10` til 6 gentag: 1 , fra $1^{\circ} 30$,

3. igûm, udriv: 30’ efterlader du.

Teksten handler som YBC 6967 (side 49) om et talpar fra reciproktabellen; i begge tekster opfattes produktet af de to som en "flade", i overensstemmelse med den geometriske repræsentation af tallene. Til gengæld er der den forskel at fladen i det nærværende tilfælde er 1, ikke 1` som i YBC 6967.

Hvad opgavens og løsningens karakter angår, kan man sammenligne med TMS IX nr. 3 (side 63). 
Str. 368

Fs

1. Et rør har jeg taget, dets mål kender jeg ikke.

2. 1 KUŠ har jeg knækket af. 1 skok (skridt) langs længden er jeg gået.

3. Hvad jeg knækkede af har jeg sat tilbage,

4. $\quad$ med 30 af det bredden er jeg gået.

5. $\quad 6 ` 15$ er fladen. Rørets begyndelse hvad?

6. Du, ved din metode,

7. $1 `$ og 30 sæt. (For) røret som du ikke kender,

8. 1 sæt, til 1 skok af den, som du er gået

9. løfter du: 1 er den falske længde.

10. 30 til dette 1 løft, 30 er den falske bredde.

11. 30, den falske bredde til 1`, den falske længde,

12. løft, 30 den falske flade.

13. 30` til 6`15, den sande flade,

Bs

1. løft: $33^{\prime \prime} 77^{\prime \prime} 30$ giver det dig.

2. 5' som du har knækket af til den falske længde løft,

3. 5 giver det dig. 5 til den falske bredde løft,

4. $2 ` 30$ giver det dig. $1 / 2$ af $2 ` 30$ bræk, $1 ` 15$

5. $\quad 1 ` 15$ lad støde sammen, $1 ` 33 ` 45$

6. til 3“'7`30` tilføj, 3“'9`3`45.

7. Hvad er den ligesidede? $134^{4} 5$ er den ligesidede.

8. $1 ` 15$ som du har ladet støde sammen, til det indvendige tilføj,

9. 15 ' giver det. IGI af 30 ', den falske flade, fraspalt, $2^{\prime \prime}$.

10. 2" til 15` løft, 30’ er rørets begyndelse.

Der er tale om endnu en »knækket-rør«-opgave, i slægt med VAT 7532 (se side 72). Til forskel fra den opgave handler den 
nærværende dog om en rektangulær mark, og røret knækker kun én gang.

\section{YBC 6504 nr. 1}

Fs

1. Så meget som længden overstiger bredden, stødt sammen (med sig selv), fra det indvendige af fladen

2. har jeg udrevet: 8`20". Længden overstiger bredden med 10'.

3. Ved din metode, 10' lader du stå mod sig selv:

4. 1'40" til 8'20" tilføjer du: 10' sætter du.

5. Halvdelen af $10^{\prime}$ bryder du: $5^{\prime}$ giver det dig.

6. $\quad 5^{\prime}$ lader du stå mod sig selv: $25^{\prime \prime}$ giver det dig.

7. 25", fladen, til 10' tilføjer du: 10`25" giver det dig.

8. $10^{\prime} 25^{\prime \prime}$ gør 25’ ligesidet. 5' til 25' tilføj:

9. $30^{\prime}$, længden, giver det dig. 5' fra $25^{\prime}$ riv ud:

10. $20^{\prime}$, bredden, giver det dig.

Opgaven handler om det samme amputerede rektangel som nr. 4 fra samme tavle (se side 89) - faktisk handler alle tavlens fire opgaver om det samme; men i denne første opgave er siden på det udrevne kvadrat kendt, så opgaven reduceres let til den typeopgave vi kender fra YBC 6967 (side 49).

Und tagelsesvis ved denne opgavetype sker tilføjelsen af de 5’ til de 25' før den tilsvarende udrivning. En anden særegenhed er brugen af det ordtegn der normalt står for »halvdel« i betydningen »halvpart«. 
YBC 6504 nr. 3

Bs

1. Så meget som længden overstiger bredden, stødt sammen (med sig selv), fra det indvendige af fladen har jeg udrevet:

2. $\quad 8^{\prime} 20^{\prime \prime} .30^{\prime}$ er længden, dets bredde er hvad?

3. $30^{\prime}$ lad støde sammen (med sig selv), 15' giver det dig.

4. $8{ }^{\prime} 20^{\prime \prime}$ fra det indvendige af $15^{\prime}$ udriv, 6`40" giver det dig.

5. Halvdelen af $30^{\prime}$ bræk, $15^{\prime}$ giver det dig.

6. $15^{\prime}$ lad støde sammen (med sig selv), 3`45" giver det dig.

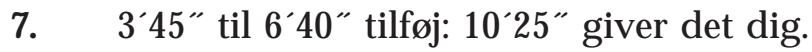

8. $10^{\prime} 25^{\prime \prime}$ gør $25^{\prime}$ ligesidet. $15^{\prime}$ fra $25^{\prime}$ udriv:

9. 10' giver det dig. 10' fra 30' riv ud,

10. 20', siden, giver det dig.
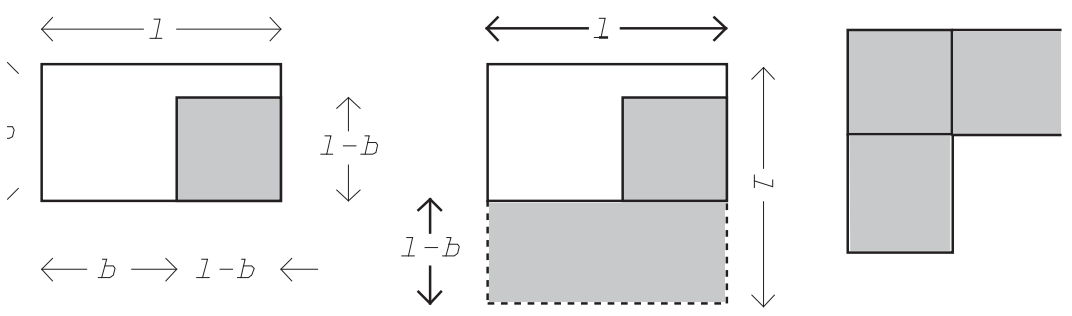

Figur 44. Geometrien bag YBC 6504 nr. 3. Let forvrængede proportioner.

Dette er den tredie opgave fra samme tavle. Løsningen benytter sig af et bemærkelsesværdigt trick (se Figur 44): Ved subtraktion af det amputerede rektangel fra kvadratet på den kendte længden $l=30^{\prime}$ fås en rest af kendt størrelse, sammensat af kvadratet $\square(l-b)$ og rektanglet $\sqsubset \sqsupset\left(l-b, 30^{\prime}\right)$. Denne rest transformeres til gnomon, som vist i figuren. I moderne sprogbrug er der tale 
om et variabelskift, men for en geometrisk betragtning er der naturligvis ingen væsentlig forskel på om det ene eller det andet af de optrædende liniestykker tages som den ubekendte.

\section{BM 85200+VAT 6599 nr. 23}

\section{Bs I}

19. En kælder. Så meget som jeg har ladet stå mod sig selv, og 1 KUŠ, overskridende: dybden. $1^{\circ} 45^{\prime}$ den jord jeg har udrevet.

20. Du, $5^{\prime}$, overskridende, til 1, omsætningen, rejs, løft, $5^{\prime}$ ser du; til 12 løft, 1 ser du.

21. 5' lad stå mod sig selv, 25" ser du. 25" til 1 løft, 25" ser du. IGI af $25^{\prime \prime}$ fraspalt,

22. $2 ` 24$ ser du. $2 ` 24$ til $1^{\circ} 45$ løft, $4 ` 12$ se du.

23. Fra (tabellen) »Ligeside, 1 tilføjet«, 6 ligesiden. 6 til 5’ løft, 30’ ser du, står mod sig selv. 7 er dybden

24. Fremgangsmåden.

Denne opgave stammer fra samme tavle som den ovenfor behandlede »kældertekst« BM 85200+VAT 6599 nr. 6 (side 99), og løses på nogenlunde samme måde. Denne gang er grundfladen kvadratisk, og dybden er 1 KUŠ større end kvadratets sidelængde. Som sammenligningslegeme vælges en terning med side 1 KUŠ, hvad der tillader brug af en tabel over $n^{2} \cdot(n+1)$, kaldet »Ligeside, 1 tilføjet«; sådanne tabeller er faktisk fundet. 


\section{$\mathrm{Db}_{2}-146$}

1. Hvis angående (et rektangel med) diagonal han har spurgt dig

2. således: $1^{\circ} 15$ er diagonalen, $45^{\prime}$ fladen,

3. længden og bredden er hvor meget? Du, ved din metode,

4. $1^{\circ} 15^{\prime}$ din diagonal og dens modstykke tegn,

5. lad dem holde, $1^{\circ} 33^{\prime} 45^{\prime \prime}$ fremkommer,

6. 1'33`45" i hånden 'behold?

7. $45^{\prime}$, din flade, indtil to gange bring: $1^{\circ} 30^{\prime}$ fremkommer,

8. fra $1^{\circ} 33^{\prime} 45^{\prime \prime}$ skær af, $3^{\prime} 45^{\prime \prime}$ er resten.

9. Den ligesidede af $3^{\prime} 45^{\prime \prime}$ tag: $15^{\prime}$ fremkommer, dets halvpart,

10. 7’30" fremkommer, til 7’30" løft: 56"15"' fremkommer,

11. 56"15"' (til din) hånd. $45^{\prime \prime}$, din flade, (overfør) til din hånd,

12. $45^{\prime} 56^{\prime \prime} 15^{\prime \prime \prime}$ fremkommer, ligesiden af $45^{\prime} 56^{\prime \prime} 15^{\prime \prime}$ tag:

13. 52'30" fremkommer, 52’30" dets modstykke tegn:

14. 7'30" som du har ladet holde, til den ene

15. tilføj; fra den anden

16. skær ud. 1 er din længde, 45’ er bredden. Hvis 1 er længden,

17. $45^{\prime}$ bredden, fladen og diagonalen hvor meget?

18. 'Du, ved? din metode, længden lad holde:

19. 1 fremkommer. 1 skal dit hoved beholde.

20. [...]: 45', bredden, lad holde:

21. $33^{\prime} 45^{\prime \prime}$ fremkommer, til din længde tilføj:

22. $1^{\circ} 33^{\prime} 45^{\prime \prime}$ fremkommer. Ligesiden af $1^{\circ} 33^{\prime} 45^{\prime \prime}$ tag:

23. $1^{\circ} 15^{\prime}$ fremkommer, $1^{\circ} 15^{\prime}$ er din diagonal. Din længde

24. til bredden løft, $45^{\prime}$ er din flade.

25. Således er metoden. 
Denne tekst hører til blandt de ældste oldbabyloniske matematiske tekster - den stammer fra det centrale Iraq og kan undtagelsesvis dateres nogenlunde præcist: ca. 1775 f.v.t. ${ }^{[28]}$ Opgaven er en af de gåder som den oldbabyloniske skriverskole overtog fra de akkadiske landmålere (jfr. side 115 og 117); den genfindes med præcis samme løsningsmetode så sent som i en hebraisk landmålingshåndbog fra 1116, ca. 3000 år senere. Der er adskillige spor af denne oprindelse i teksten - blandt
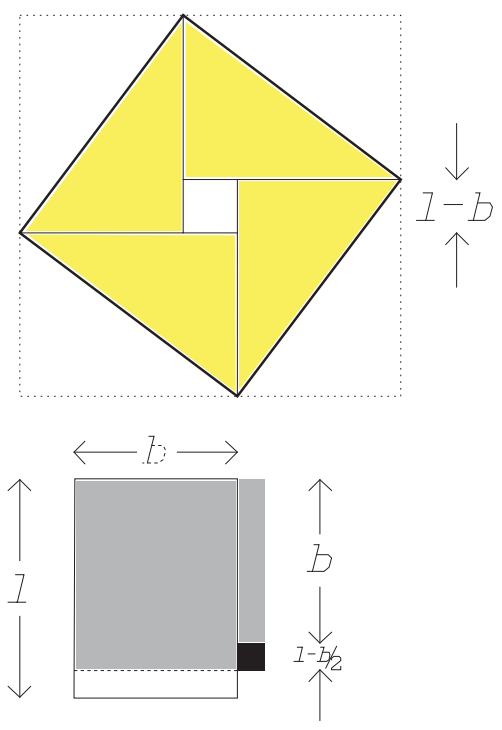

Figur 45. Geometrien i $\mathrm{Db}_{2}-146$. andet det indledende »Hvis [...] han har spurgt dig således«; $i$ andre henseender er opgaven dog allerede præget af sit tilhørsforhold til skriverskolen.

I linie 1-9 beregnes differensen mellem rektanglets længde og bredde; metoden fremgår af den øverste del af Figur 45. Dernæst findes rektanglets sider ud fra denne differens og arealet. Metoden er den samme som vi kender fra bl.a. YBC 6967 (se side 49), og svarer til den nederste del af figuren. Men der er tydelige tegn på at vi denne gang har at gøre med »hovedgeome-

\footnotetext{
${ }^{28}$ Teksten findes ikke i de tekstudgaver der præsenteres i den bibliografiske oversigt. Den er taget fra Taha Baqir, “Tell Dhiba'i: New Mathematical Texts". Sumer 18 (1962), 11-14, pl. 1-3.
} 
tri«; arealerne af kvadratet på den halve sidedifferens og af rektanglet selv gemmes »i hånden « (linie 11), antagelig på et stykke kladde-ler. Kvadratet på den halve sidedifferens findes også ved løftning, ikke ved at det lades holde (selv om denne proces underforstås, som det ses i linie 14). Først da den halve sum af siderne er fundet i linie 13, »tegnes « den sammen med sit modstykke (og om der her er tale om håndgribelig og ikke tænkt tegning kan vi ikke vide). 